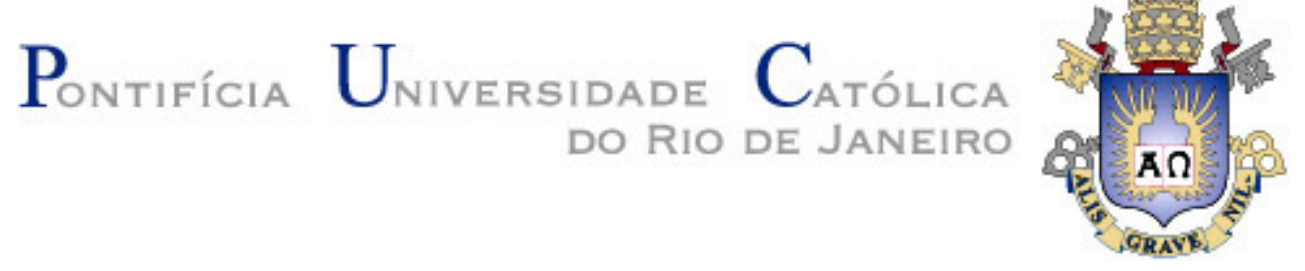

Guilherme Hiroshi Atsumi

A Percepção de Docentes e Discentes sobre as Ações de Sustentabilidade em Universidades

Dissertação de Mestrado

Dissertação apresentada ao Programa de Pósgraduação em Administração de Empresas da PUCRio como requisito parcial para obtenção do grau de Mestre em Administração de Empresas

Orientador: Prof. Marcos Cohen 
Guilherme Hiroshi Atsumi

\section{A Percepção de Docentes e Discentes sobre as Ações de Sustentabilidade em Universidades}

Dissertação apresentada como requisito parcial para obtenção do grau de Mestre pelo Programa de PósGraduação em Administração de Empresas da PUC-Rio. Aprovada pela Comissão Examinadora abaixo assinada.

Prof. Luiz Felipe Guanaes Rego Departamento de Geografia - PUC-Rio

Prof. Ronaldo Mota Universidade Estácio de Sá

Prof. Augusto Cesar Pinheiro da Silva Vice-Decano de Pós-Graduação do CCS - PUC-Rio 
Todos os direitos reservados. É proibida a reprodução total ou parcial do trabalho sem autorização da universidade, do autor e do orientador.

\section{Guilherme Hiroshi Atsumi}

Graduou-se em Engenharia de Produção em 2010 pela Universidade Federal do Rio de Janeiro. Tem certificação em negócios sociais, atua em projetos sociais e ambientais como voluntário. É gestor de projetos educacionais e de tecnologias para a educação, aplicando metodologias ágeis e cooperativas.

Ficha Catalográfica

Atsumi, Guilherme Hiroshi

A percepção de docentes e discentes sobre as ações de sustentabilidade em universidades / Guilherme Hiroshi Atsumi ; orientador: Marcos Cohen. -2018.

123 f. : il. color. ; $30 \mathrm{~cm}$

Dissertação (mestrado)-Pontifícia Universidade Católica do Rio de Janeiro, Departamento de Administração, 2018.

Inclui bibliografia

1. Administração - Teses. 2. Desenvolvimento sustentável. 3. Ensino superior. 4. Percepção. 5. Campus. 6. Comunidade. I. Cohen, Marcos. II. Pontifícia Universidade Católica do Rio de Janeiro. Departamento de Administração. III. Título. 


\section{Agradecimentos}

Primeiramente agradeço a Deus e à espiritualidade por me guiarem ao longo do caminho e no desenvolvimento deste trabalho.

Agradeço também aos meus pais e a minha família, por me ofertarem o suporte e incentivo nestes anos de esforço e dedicação ao trabalho acadêmico. Em especial, agradeço a minha mãe, sempre muito presente e atenciosa, que me forneceu estrutura e ajuda para que a tarefa fosse cumprida.

Outro agradecimento dedico para a minha companheira, que me apoiou em todo o processo e de forma muito amorosa e compreensiva, possibilitou que eu pudesse continuar, sempre com palavras de incentivo e carinho.

Agradeço ao meu orientador, pela dedicação e paciência na orientação, por todos os conselhos e direcionamentos dados para a conclusão da pesquisa.

Aos entrevistados, agradeço pelo tempo cedido e pela disposição em participar deste trabalho.

Aos respondentes e todos que colaboraram na a divulgação do questionário, sem vocês o trabalho não seria possível.

Aos pesquisadores que já escreveram e dissertaram sobre o tema, agradeço por construírem base teórica para que a ideia do trabalho fosse desenvolvida e aplicada.

A todos aqueles que possam se interessar pelo tema e por ler essa dissertação, agradeço pelo tempo dedicado e espero que de alguma forma, este trabalho possa contribuir para que os conceitos do desenvolvimento sustentável sejam mais difundidos e aplicados. 


\section{Resumo}

Atsumi, Guilherme Hiroshi; Cohen, Marcos. A Percepção de Docentes e Discentes sobre as Ações Socioambientais em Universidades. Rio de Janeiro, 2018. 123p. Dissertação de Mestrado - Departamento de Administração, Pontifícia Universidade Católica do Rio de Janeiro.

Em tempos de mudanças de paradigmas, a sustentabilidade é assunto recorrente nos noticiários e no meio acadêmico. As universidades, caracterizadas como centros de formação profissional e espaços de diálogos, têm grande responsabilidade na educação para o desenvolvimento sustentável, já que formam grande parte de novos gestores, empreendedores e profissionais liberais. Esta pesquisa, de caráter descritivo, buscou medir a percepção de docentes e discentes sobre as ações desenvolvidas para o desenvolvimento sustentável de uma instituição privada de ensino superior do Rio de Janeiro, nas dimensões Campus, Comunidade e Educação. A coleta de dados foi realizada através de um questionário online, com um total de 758 respostas válidas. Foi também realizada uma entrevista com uma representante da instituição, como forma de conhecer como a universidade se coloca frente ao desafio do desenvolvimento sustentável. O método utilizado para a análise de dados consistiu no uso de análise fatorial e de análise multivariada de variâncias de dados não-paramétricos. Assim, foi possível criar um modelo de hipóteses para testar estatisticamente se fatores como percepção, satisfação e participação em ações para o desenvolvimento sustentável se relacionam. A análise de resultados permitiu observar como os respondentes percebem as ações da universidade nas dimensões do estudo, além de aferir a satisfação com as ações desenvolvidas, a participação em atividades para o desenvolvimento sustentável e atitudes e comportamentos individuais. Também foi realizada uma análise descritiva das respostas coletadas no questionário, que junto com os resultados dos testes e das entrevistas, contribuíram para que os objetivos propostos do trabalho fossem atendidos.

\section{Palavras-chave}

Desenvolvimento sustentável; ensino superior; percepção; campus; comunidade. 


\section{Abstract}

Atsumi, Guilherme Hiroshi; Cohen, Marcos (Advisor). The Perception of Stakeholders about Universities' Sustainable Actions. Rio de Janeiro, 2018. 123p. Dissertação de Mestrado - Departamento de Administração, Pontifícia Universidade Católica do Rio de Janeiro.

In times of paradigm shifts, sustainability is a recurrent issue on the news and the academic circles. Universities, characterized as centers of professional training and dialogue space, have a great responsibility in education for sustainable development, since they form a large part of new managers, entrepreneurs and liberal professionals. This descriptive research aimed to measure the perception of students and teachers about the actions for sustainable development developed by a private institution of higher education in Rio de Janeiro, in the dimensions Campus, Community and Education. The data collection was performed through an online questionnaire, with a total of 758 valid answers. An interview was also conducted with a representative of the institution, to identify how the university is facing the challenge of sustainable development. The method used for data analysis consisted of the use of factorial analysis and multivariate analysis of non-parametric data variances. Thus, it was possible to create a model of hypotheses to statistically test whether factors such as perception, satisfaction and participation in actions for sustainable development are related. The analysis of results allowed us to observe how the respondents perceive the actions of the university in the dimensions of the study, besides assessing satisfaction with the actions developed, participation in activities for sustainable development and individual attitudes and behaviors. A descriptive analysis of the responses collected in the questionnaire was also performed, which, together with the results of the tests and the interviews, contributed to the achievement of the proposed objectives of the study.

\section{Keywords}

Sustainable development; higher education; perception; campus; community. 


\section{Sumário}

1 O problema 11

1.1. Introdução 11

1.2. Objetivo final 12

1.3. Objetivos Intermediários $\quad 13$

1.4. Delimitação do estudo 13

1.5. Relevância do estudo 14

$\begin{array}{ll}\text { 1.6. Estrutura do relatório } & 14\end{array}$

2 Referencial Teórico $\quad 15$

2.1. Evolução do Pensamento Sustentável 15

2.2. Desenvolvimento Sustentável e Sustentabilidade 19

2.3. Triple Bottom Line e Sustentabilidade nas Organizações 22

2.4. Ensino Superior e Sustentabilidade $\quad 27$

2.4.1. Educação Superior no Brasil 27

2.4.2. Acordos da Educação para o Desenvolvimento Sustentável 29

2.4.3. Papel das Universidades para a Sustentabilidade 34

2.4.4. Educação para o Desenvolvimento Sustentável 37

2.4.5. Dimensões do Desenvolvimento Sustentável no Ensino Superior 41

3 Metodologia 44

3.1. Tipos de pesquisa 44

3.1.1. Quanto aos fins e aos meios 45

3.2. Universo e amostra 49

3.3. Seleção dos sujeitos 49

3.4. Procedimentos e Instrumentos de Coleta de Dados 50

3.5. Tratamento dos dados $\quad 55$

3.6. Limitações do Método 63

4 Análise e Interpretação dos Resultados 64

4.1. Análise dos dados qualitativos 64

4.2. Análise e Interpretação dos dados quantitativos 66

5 Conclusão 94

6 Referências Bibliográficas $\quad 99$

$\begin{array}{lr}\text { Anexo } 1 & 108\end{array}$ 


\section{Lista de figuras}

Figura 1: Evolução da pegada ecológica $(1961$ - 2013) ................................. 18

Figura 2: Triple Bottom Line.................................................................... 24

Figura 3: Estrutura da dissertação ........................................................... 45

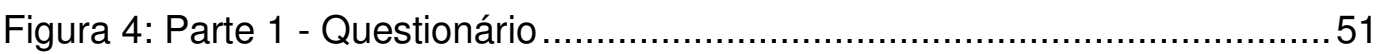

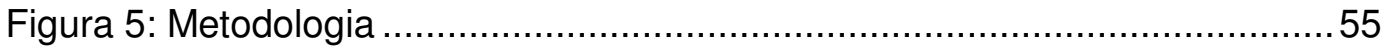

Figura 6: Teste de Alfa de Cronbach .........................................................56

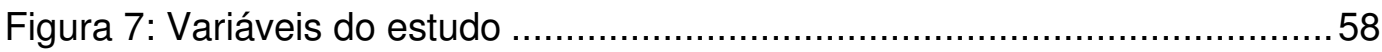

Figura 8: Modelo Conceitual e Hipóteses do estudo .......................................59

Figura 9: Estatística de Teste - MANOVA não-paramétrica..............................61

Figura 10: Respostas por sexo - Instituição X .............................................66

Figura 11: Respostas por idade - Instituição X ...........................................67

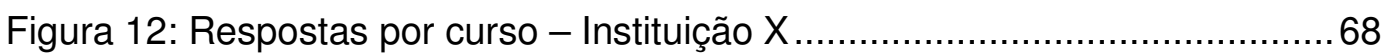

Figura 13: \% das respostas por público - Instituição X - Atitude .......................70

Figura 14: \% das respostas por público - Instituição $X$ - Comportamento......... 72

Figura 15: \% das respostas por público - Instituição $X$ - Campus ..................... 74

Figura 16: \% das respostas por público - Instituição $X$ - Comunidade .............. 76

Figura 17: \% das respostas por público - Instituição $X$ - Educação ...................78

Figura 18: \% das respostas por público - Instituição $X$ - Promoção .................. 79

Figura 19: \% das respostas por público - Instituição $X$ - Satisfação................... 81

Figura 20: Respostas por público - Instituição X - Participação ........................ 82

Figura 21: Instituição X - Hipótese 1 - Campus ................................................. 84

Figura 22: Instituição X - Hipótese 1 - Satisfação Campus ............................... 85

Figura 23: Instituição X - Hipótese 1 - Comunidade ...................................... 86

Figura 24: Instituição X - Hipótese 1 - Satisfação Comunidade .......................... 86

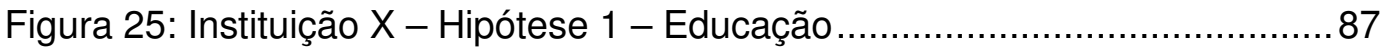

Figura 26: Instituição X - Hipótese 1 - Satisfação Educação ............................ 88

Figura 27: Instituição X - Hipótese 1 - Percepção e Satisfação por dimensão .. 89

Figura 28: Instituição $X$ - Hipótese 1 - Percepção............................................. 89

Figura 29: Instituição X - Hipótese 1 - Satisfação Percepção ...........................90 90

Figura 30: Instituição X - Hipótese 2 - Satisfação por dimensão........................91

Figura 31: Instituição X - Hipótese 2 - Satisfação e NívelParticipação...............92 


\section{Lista de tabelas}

Tabela 1: Distribuições das IES por tipo no Brasil.........................................2

Tabela 2: Conferências sobre educação e desenvolvimento sustentável............33

Tabela 3: Mudanças de aprendizagem para o desenvolvimento sustentável.....39

Tabela 4: Estudos sobre percepções em universidades .................................. 48

Tabela 5: Perguntas do roteiro de entrevista para a instituição de ensino..........50

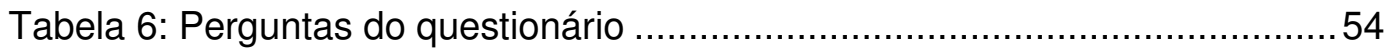

Tabela 7: Médias Atitude - Instituição X ...................................................... 70

Tabela 8: Médias Comportamento - Instituição X ............................................ 72

Tabela 9: Médias Campus - Instituição X .................................................... 74

Tabela 10: Médias Comunidade - Instituição X .............................................76

Tabela 11: Médias Educação - Instituição X .................................................. 78

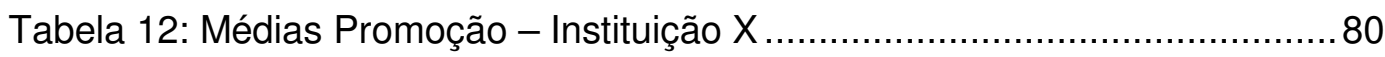

Tabela 13: Médias Satisfação - Instituição X.................................................. 81

Tabela 14: Respondentes e Média - dimensão Participação .............................. 82

Tabela 15: Médias Satisfação - Instituição X................................................. 83 
"De nada serve ao homem conquistar a Lua se acaba por perder a Terra"

François Mauriac 


\section{O problema}

1.1.

Introdução

De acordo com Elkington (2001), o atual sistema de produção baseado no consumo excessivo de recursos naturais incorre em problemas que evidenciam que sua natureza é socialmente injusta, ambientalmente desequilibrada e economicamente inviável para grande parte da população mundial, especialmente para aqueles com menor poder aquisitivo e acesso restrito a bens e serviços.

A crescente discussão acerca do tema sustentabilidade tem envolvido governos, empresas, sociedade civil e universidades, que percebem sua importância e a necessidade de não o tratar de maneira isolada, como apenas práticas empresariais ou ações apartadas de alguns indivíduos ou organizações. Nesse sentido, cresce a consciência nas organizações de que a sustentabilidade é uma necessidade imposta pela sociedade a ser incorporada em seus conceitos e princípios, bem como na gestão das operações (PEDROSO, 2007).

Não obstante, Costanza (1991) recomenda que o conceito de desenvolvimento sustentável deve ser inserido na relação dinâmica entre o sistema econômico e um sistema maior, o ecológico, com taxa de mudança mais lenta e entendido como o ciclo da natureza. Ainda segundo Costanza (1991), para ser sustentável, essa relação deve assegurar que a vida humana possa crescer e desenvolver sua cultura, indefinidamente, de modo que os efeitos das atividades humanas sejam controlados e mantidos dentro de fronteiras adequadas, para não destruir a diversidade, a complexidade e as funções dos sistemas naturais de suporte à vida.

O contexto mundial contemporâneo, marcado por mudanças de paradigmas e com a presença de tecnologias digitais que permitem a melhor compreensão do mundo, requer atenção e ações propositivas para a sustentabilidade e preservação do planeta, pois estamos inseridos na natureza e sujeitos a mudanças ambientais, sociais e econômicas, notadamente ameaçadoras à continuidade da espécie humana no planeta. Dessa forma, é necessário um programa de educação para o desenvolvimento sustentável, o 
qual exige um reexame da política educacional, a fim de enfocar a aquisição de conhecimentos, competências, perspectivas e valores relacionados com a sustentabilidade (UNESCO, 2005).

Além de sua atuação como atores globais na discussão e reflexão sobre a sustentabilidade, cabe também às instituições de ensino, em todos os níveis e pontualmente no ensino superior, fazer sua parte desenvolvendo tecnologia e material humano para atender à demanda ambiental e assumindo uma postura responsável em suas operações (ANTUNES, 2001), de forma que atitudes individualistas sejam redirecionadas para questões coletivas.

As universidades têm em sua missão a formação profissional, portanto é um espaço para futuros gestores de empresas, profissionais liberais, empreendedores e formadores de opinião. Nesse sentido, a conscientização de discentes (doravante denominados "alunos") e docentes é fator fundamental para a promoção do desenvolvimento sustentável, visando a um futuro em que as condições de sustentabilidade econômica, social e ambiental sejam atingidas e que os atores tenham cada vez mais atuação protagonista como agentes de transformação e disseminação de práticas sustentáveis (STEPHENS et al., 2008).

A partir deste complexo contexto do ensino superior, pergunta-se:

$\checkmark$ Como alunos e docentes das universidades entendem e praticam a sustentabilidade?

$\checkmark$ Como alunos e docentes percebem se as universidades atuam de maneira responsável em relação a aspectos sociais e ambientais?

$\checkmark$ Alunos e docentes estão satisfeitos com as ações das universidades visando à sustentabilidade?

$\checkmark$ Alunos e docentes estão dispostos a colaborar com as universidades em ações visando à sustentabilidade?

\section{2.}

\section{Objetivo final}

Este trabalho pretende identificar como docentes e alunos de uma instituição de ensino superior no Rio de Janeiro percebem as ações para a sustentabilidade realizadas pela universidade, nas dimensões campus, comunidade e educação. 
Objetiva-se identificar se as percepções, geral e por dimensão, dos respondentes têm relação com sua satisfação com as ações desenvolvidas pela universidade para o alcance da sustentabilidade.

Objetiva-se também verificar se alunos e docentes com percepção mais positiva das ações da universidade estão mais propensos a colaborar em ações futuras para o alcance da sustentabilidade pela universidade.

\section{3.}

\section{Objetivos Intermediários}

Para se atingir os objetivos finais propostos é preciso analisar fatores relacionados a práticas individuais, identificando atitudes e comportamentos de cada indivíduo para o desenvolvimento sustentável. Dessa forma, este estudo prevê, como objetivos intermediários a serem alcançados:

$\checkmark$ Identificar se fatores como atitude e comportamento influenciam a percepção das ações realizadas pelas universidades;

$\checkmark$ Identificar como alunos e docentes percebem o desenvolvimento sustentável e como as universidades atuam.

\section{4.}

\section{Delimitação do estudo}

Este estudo se volta mais especificamente para abordar a questão da percepção do desenvolvimento sustentável em uma instituição privada de ensino superior da cidade do Rio de Janeiro sob o ponto de vista específico de como docentes e alunos que se relacionam com a instituição percebem as ações da universidade para o desenvolvimento sustentável. Tal ângulo de análise se mostra interessante e importante porque, em um contexto em que mudanças de paradigmas são necessárias para a garantia da continuidade da vida humana no planeta, o modo como o desenvolvimento sustentável é visto e percebido dentro das instituições de ensino pode fornecer reflexões sobre o tipo de ensino e como educamos a sociedade.

Embora relevante, não se pretende tratar da questão da sustentabilidade em instituições públicas de ensino superior no Brasil, mas apenas para o caso específico analisado, já que a perspectiva do desenvolvimento sustentável deve ser entendida localmente e de acordo com as especificidades de cada região em que as instituições de ensino estão inseridas. Não será debatido também a estrutura curricular da universidade estudada e quais são as disciplinas ofertadas nos cursos, já que o estudo não tem por objetivo realizar pesquisa documental sobre as ementas e conteúdos ministrados aos alunos. 


\section{5 . \\ Relevância do estudo}

Como contribuição teórica este estudo apresenta elementos sobre o papel das instituições de ensino superior no contexto da sustentabilidade, além de levantar se o direcionamento da universidade está alinhado com os anseios de alunos e docentes.

O trabalho pode oferecer informações para análises mais profundas de demais pesquisadores ou confrontado com outros estudos relacionados aos temas da sustentabilidade, ensino superior e educação para a sustentabilidade.

Como contribuição prática, o resultado deste estudo poderá ser utilizado como base para a implementação de práticas para o desenvolvimento sustentável na IES (Instituição de Ensino Superior), por fornecer informações sobre como são percebidas as ações para a sustentabilidade por aqueles que estão em contato diário com a instituição. As informações constituem base de dados sobre as inclinações, satisfação e percepções de ações para as instituições.

O presente trabalho também poderá ser utilizado como fonte para outras organizações sobre como desenvolver estratégias para a sustentabilidade no âmbito da educação superior, e sobre o impacto de suas ações em todas as dimensões que a sustentabilidade requer para uma instituição de ensino superior.

Por fim, os resultados apresentados podem ser utilizados para interesse geral, para organizações da sociedade civil, estudantes, docentes e interessados em educação e de como queremos formar futuras gerações, tendo em vista os problemas, especificidades e potencialidades das instituições de ensino superior.

\section{6.}

\section{Estrutura do relatório}

A estrutura do trabalho desenvolve-se a partir desta etapa da introdução, (Capítulo 1) apresentando o contexto da pesquisa: justificativa, problemática, objetivos e relevância do estudo.

No Capítulo 2 é apresentada a revisão da literatura abordando os temas do desenvolvimento sustentável e sustentabilidade em organizações e da educação e das instituições de ensino superior no âmbito da sustentabilidade.

Finalmente, seguem descritas em capítulos individuais: a metodologia (Capítulo 3) utilizada, a análise dos resultados da pesquisa aplicada (Capítulo 4) e, por desfecho, as conclusões (Capítulo 5). 


\section{2 \\ Referencial teórico}

Neste capítulo são discutidos aspectos teóricos e estudos relacionados ao tema da pesquisa. Esta seção está dividida em quatro partes e abordam, respectivamente, a evolução do conceito sustentabilidade ao longo do tempo, as definições de desenvolvimento sustentável e sustentabilidade, como o assunto é visto dentro das corporações através do conceito triple bottom line e a educação superior e suas interrelações com a sustentabilidade.

\section{1. \\ Evolução do pensamento sustentável}

No último século o planeta teve crescimento demográfico jamais registrado. De acordo com a ONU, éramos 1,6 bilhões no início do século XX e finalizamos em 6 bilhões de habitantes no ano 2000. Os últimos dezoito anos não fogem à regra e hoje contamos com cerca de 7,5 bilhões de habitantes. $A$ atual taxa de crescimento populacional é de $1,13 \%$ ao ano, ou seja, um incremento de aproximadamente 80 milhões de pessoas a cada ano. Para LÉLÉ (1991), com o elevado padrão de consumo registrado em países desenvolvidos e com os níveis de extração de recursos naturais sendo cada mais vez expandidos, a sociedade se vê em uma situação de necessária mudança comportamental, com um olhar mais atento às questões climáticas e sociais, acentuadas pelo contínuo aumento da população.

Como efeito do aumento da produção sem controles, se tem observado a piora da situação social global, como o aumento da concentração de riqueza, da pobreza, da desigualdade social e além de consequências ambientais negativas. Neste cenário, têm surgido novas formas de relacionamento com o planeta, com novas correntes de pensamentos, estudos e pesquisas para melhorar a interação do homem entre si e com o meio ambiente (OLIVEIRA et al., 2012)

De acordo com SOUSA et al. (2011), a partir da década de 70 a consciência sobre questões ambientais se desenvolveu mais intensamente e começou a ter impactos e reflexos em grandes empresas na época, muitas caracterizadas como grandes poluidoras. Diante do cenário, muitas dessas corporações precisaram se reinventar e passar a atuar de forma ativa no 
processo para a sustentabilidade ambiental, já que esta começava a ser percebido como necessário para atender as necessidades vigentes da população sem comprometer o futuro das próximas gerações.

Locatelli (2000, p. 297) cita que "ao contrário dos anseios e necessidades do homem, que podem ser consideradas como ilimitados, os recursos naturais disponíveis não o são", concordando com Penna (1999), que comenta que a capacidade de regeneração dos recursos naturais do planeta não é suficiente para atender aos anseios de crescimento do homem, cuja demanda parece não haver limites, apesar da já conhecida limitação de abastecimento de recursos naturais.

$\mathrm{Na}$ década de 1980, a discussão sobre questões socioambientais continuou em voga. No Relatório de Brundtland, publicado pela Comissão Mundial sobre o Meio Ambiente e o Desenvolvimento (CMMAD,1987), também conhecido por "Nosso Futuro Comum", foi definido o conceito de Desenvolvimento Sustentável: o desenvolvimento que satisfaz as necessidades atuais, sem comprometer a capacidade das gerações futuras de suprir suas próprias necessidades. O relatório aponta para a incompatibilidade entre desenvolvimento sustentável e os padrões de produção e consumo vigentes, tendo sido aceito por praticamente todos os países participantes da ONU, aumentando a importância do assunto dentro do mundo empresarial (OLIVEIRA et al., 2012).

Para Lima (2012), a definição de desenvolvimento sustentável veiculada pelo Relatório Brundtland começava a criar raízes ideológicas sobre a possibilidade de haver um desenvolvimento pautado no crescimento econômico com limites, no contexto de acumulação do capital. No entanto, segundo a autora, o Relatório orienta-se segundo a lógica da política neoliberal como alternativa para se manter os atuais níveis de consumo, aliando o discurso entre sustentabilidade econômica e ecológica, sem alterar questões mais profundas do tema, como distribuição de renda e direitos humanos.

A Conferência do Rio, também conhecida por Rio-92 ou ECO 92, evento das Nações Unidas sobre Gestão Ambiental e Desenvolvimento Sustentável teve como principais produtos dois documentos: A Carta da Terra e a Agenda 21, sendo que neste último foram listadas ações para a promoção da sustentabilidade que devem ser tomadas por diversos atores da sociedade em busca do desenvolvimento sustentável, como governos, empresas, grupos organizados e indivíduos (CNUMAD, 1992). 
Dez anos após a ECO 92, em 2002, foi realizada a Cúpula Mundial sobre Desenvolvimento Sustentável na África do Sul, evento que ficou conhecido por Rio +10 . Nele foram resgatadas e atualizadas as metas da Agenda 21 na busca pela promoção da sustentabilidade. De acordo com Lima (2012), a conferência foi uma nova tentativa de validar a manutenção do crescimento econômico sem alterar a lógica de acumulação do capital, não tendo sido registrados avanços ou metas do desenvolvimento de países pobres, como questões relacionadas à dívida externa ou subsídios para exportação agrícola.

Em 2012, aconteceu a Rio +20, evento onde foram debatidos importantes temas relacionados ao futuro do planeta e ao alcance das ações dispostas em duas décadas após a realização da ECO 92. As discussões foram orientadas a partir de dois temas: economia verde e a governança para o desenvolvimento sustentável. De acordo com o PNUMA (2011, p. 01), ficou definido como "economia verde uma economia que resulta em melhoria do bem-estar da humanidade e igualdade social, ao mesmo tempo em que reduz significativamente riscos ambientais e escassez ecológica”.

Para Guimarães e Fontoura (2012), o assunto "Economia Verde" como ferramenta para o desenvolvimento sustentável acabou sendo o principal foco da conferência, ao invés de debater os temas de real necessidade, como a questão energética, biodiversidade, impactos do agronegócio (concentração de terras, utilização de agrotóxicos, monocultura) e direitos humanos. No mesmo artigo, os autores sustentam que o texto final da conferência ficou vago, sem ações concretas ao desenvolvimento sustentável, ressaltando apenas a necessidade de uma economia orientada para a sustentabilidade.

Melo et al. (2012) argumentam que o relatório da RIO +20 reforçou o posicionamento privilegiado dos países ricos, em um cenário em que os países em desenvolvimento permanecem em situações menos privilegiadas, já que o documento não aponta caminhos ou formas de alterar a situação de domínio de produção e do comércio internacional pelos países ricos. Em última análise, Oliveira (2012) aponta que são necessárias mudanças de valores, de integração entre diferentes conhecimentos para um progresso comum, e que ações propositivas precisam sair da esfera internacional para o debate em escala nacional e local, mas que ainda esbarram em questões políticas, já que segundo Guimarães e Fontoura (p. 524, 2012), a vontade política de agir "se demonstrou insuficiente durante a conferência, passando a representar a principal barreira para o desenvolvimento sustentável". 
Em 2015, foi realizada em Paris a COP21 (21a sessão anual da Conferência das Partes das Nações Unidas de 1992 - Convenção-Quadro sobre a Mudança do Clima). O acordo firmado por 195 nações (COP21, 2015) ratificou o objetivo de alcançar a sustentabilidade e a necessidade de integração entre os países desenvolvidos e menos desenvolvidos. Em um contexto da vida moderna em que alterações climáticas e seus impactos são sentidos em todo o mundo, o Acordo de Paris busca se pautar pela ótica da distribuição justa de esforços e responsabilidades, assumindo que o cenário é grave e precisa de novas e efetivas formas de cooperação (GUERRA, SCHMIDT, 2016).

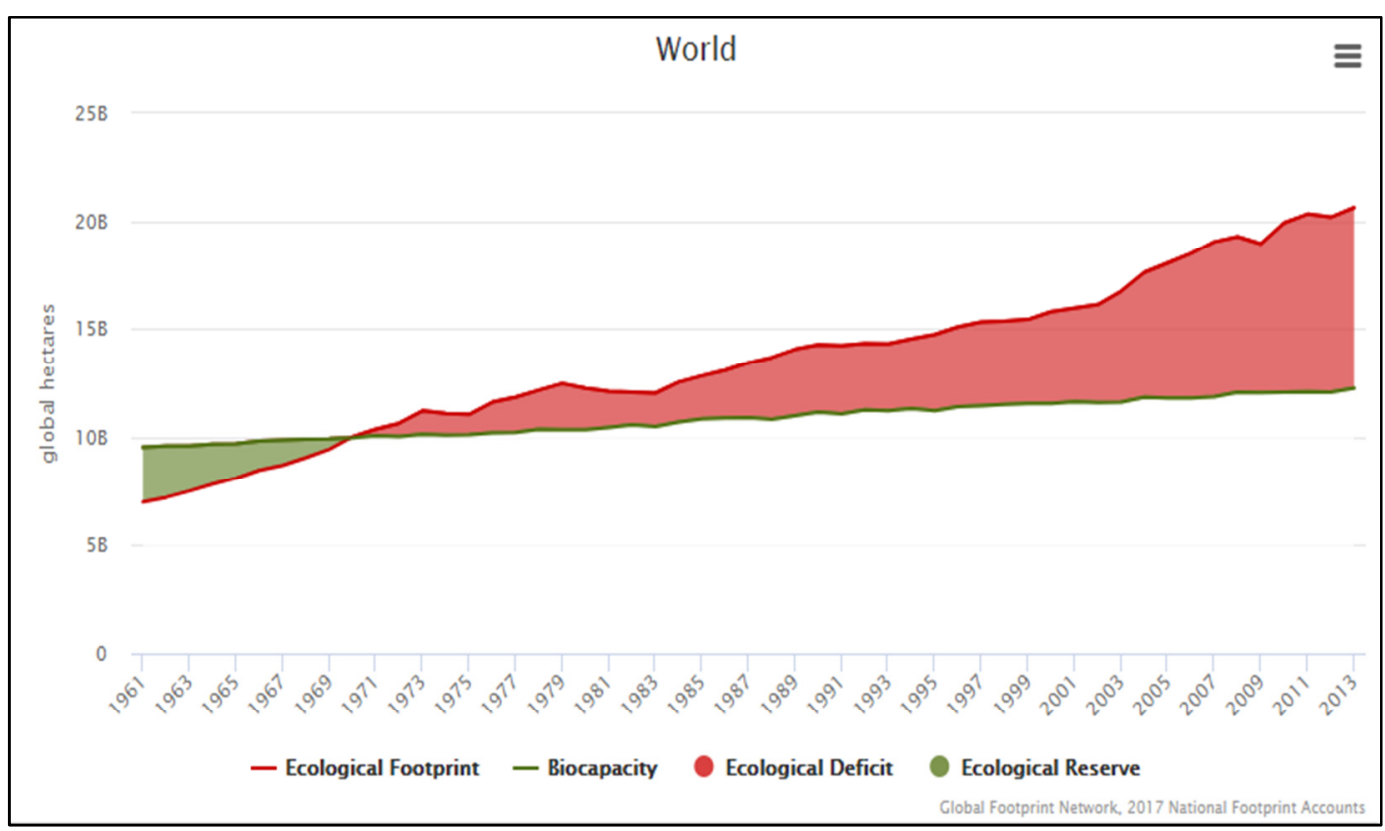

Figura 1: Evolução da pegada ecológica (1961 - 2013)

Fonte: Global Footprint Network, 2017

A Figura 1 mostra que, de acordo com a Global Footprint Network, seriam necessárias cerca de 22 Terras para suprir o atual nível de consumo e utilização de recursos em condições que garantam a biocapacidade do planeta. Para Guerra e Schmidt (2016), é evidente que o modelo de consumo da sociedade aumenta o déficit ambiental e social, e mantém a maioria dos países afastados da sustentabilidade, já que os mais ricos, grandes ofensores ambientais, causam maior impacto em virtude de seu excessivo consumo, enquanto que os mais pobres são impactados pela escassez de recursos e da distribuição não equitativa de renda, que agrava a condição social desses países. 


\section{2. \\ Desenvolvimento sustentável e sustentabilidade}

Pereira e Curi (2012) sustentam que crescimento e desenvolvimento são termos que são confundidos, mas com diferentes significados. O crescimento é condição necessária para que haja o desenvolvimento, mas refere-se apenas a incrementos quantitativos ao passo que desenvolvimento se refere a incrementos qualitativos. Cortese (2003) cita que os fatores limitantes para o crescimento econômico não são relativos a tecnologia ou pessoas. Os limitantes são o fator natural, como por exemplo o número de peixes disponíveis, e não a capacidade de pesca, e o fator social, como habilidade de se realizar correções de mercado e governar a sociedade de forma a se garantir saúde, segurança, igualdade social e estabilidade para a população. Para Stephens et al. (2008), a mudança no padrão das atividades diárias e no estilo de vida são necessárias, mas a transição é complexa e exige mudanças amplas nas prioridades e perspectivas da atual sociedade.

Van Bellen (2004) aponta que o desenvolvimento sustentável pode ser considerado quando o crescimento econômico é obtido sem prejuízo aos recursos naturais finitos, respeitando as fronteiras de renovação de recursos, com justiça social e oportunidade para todos, de modo a não destruir a diversidade e os sistemas ecológicos que suportam a vida além de assegurar o desenvolvimento da vida humana e de suas culturas.

Para Sartori et al. (2014), o conceito de desenvolvimento sustentável incorpora aspectos multidimensionais, buscando a proteção ambiental e a conservação de recursos naturais como meios para a prosperidade econômica e como forma de garantia de a sobrevivência das gerações atuais e futuras. Já Pereira e Curi (2012) comentam que o termo desenvolvimento sustentável pode ser ambíguo, já que o termo desenvolvimento historicamente aparece inserido em uma lógica de exploração ilimitada, com o lucro como prioridade, onde aspectos sociais e ambientais se distanciam do crescimento acelerado da economia.

Cabe ressaltar que o desenvolvimento sustentável é visto como uma referência para a mudança no comportamento da humanidade, com ações e ferramentas que visam a sobrevivência da vida humana, em uma relação harmoniosa com os meios e sistemas naturais. Dessa forma, o desenvolvimento sustentável pode ser traduzido em hábitos e em como agir, em que as pessoas devem ter a intenção de evitar gerar consequências negativas decorrentes de suas ações, nos âmbitos sociais, ambientais e econômicos. O progresso pode 
ser então aplicado, principalmente, na população humana e em seu bem-estar social, onde o crescimento econômico seja baseado na justiça, equidade social e na utilização consciente e eficiente de recursos naturais (FEIL, SCHREIBER, 2017).

Por ser o desenvolvimento sustentável de difícil aferição, diversas técnicas de mensuração foram criadas como tentativas de se obter dados para tomadas de decisão, como o Índice de Desenvolvimento Humano - IDH (1990), PressãoEstado-Resposta (1993), Pegada Ecológica (1995), Força-Motriz-EstadoResposta (1996), Barômetro da Sustentabilidade (1997) e o Painel da Sustentabilidade (1999).

O Índice de Desenvolvimento Humano (IDH) contempla em sua fórmula de cálculo os índices de educação, a longevidade da população e a renda, este último tendo como base o PIB (Produto Interno Bruto) por pessoa, e é um dos principais instrumentos para medir o grau de desenvolvimento dos países. $\mathrm{O} I D H$ permitiu que as discussões sobre desenvolvimento sustentável fossem aumentadas, já que agora existia um indicador que seria possível avaliar, ainda que primariamente, o grau de desenvolvimento das nações. Sena et al. (2017) discutem que diversas críticas surgiram ao IDH por utilizar apenas três critérios para avaliar o desenvolvimento e que poderia ser incluído um indicador relacionado à qualidade do meio ambiente.

Em 2017, na cidade de Nova lorque, EUA, chefes de Estado e de Governo se reuniram e assinaram a Agenda 2030, um plano de ação para as pessoas, Estados e sociedade no qual foram definidos 17 novos objetivos e 169 metas para o desenvolvimento sustentável (UNESCO, 2017, p. 6). Os objetivos definidos são:

- Objetivo 1. Acabar com a pobreza em todas as suas formas, em todos os lugares;

- Objetivo 2. Acabar com a fome, alcançar a segurança alimentar e melhoria da nutrição e promover a agricultura sustentável;

- Objetivo 3. Assegurar uma vida saudável e promover o bem-estar para todos, em todas as idades;

- Objetivo 4. Assegurar a educação inclusiva e equitativa e de qualidade, e promover oportunidades de aprendizagem ao longo da vida para todos;

- Objetivo 5. Alcançar a igualdade de gênero e empoderar todas as mulheres e meninas; 
- Objetivo 6. Assegurar a disponibilidade e gestão sustentável da água e saneamento para todos;

- Objetivo 7. Assegurar o acesso confiável, sustentável, moderno e a preço acessível à energia para todos;

- Objetivo 8. Promover o crescimento econômico sustentado, inclusivo e sustentável, emprego pleno e produtivo e trabalho decente para todos;

- Objetivo 9. Construir infraestruturas resilientes, promover a industrialização inclusiva e sustentável e fomentar a inovação;

- Objetivo 10. Reduzir a desigualdade dentro dos países e entre eles;

- Objetivo 11. Tornar as cidades e os assentamentos humanos inclusivos, seguros, resilientes e sustentáveis;

- Objetivo 12. Assegurar padrões de produção e de consumo sustentáveis;

- Objetivo 13. Tomar medidas urgentes para combater a mudança do clima e seus impactos;

- Objetivo 14. Conservação e uso sustentável dos oceanos, dos mares e dos recursos marinhos para o desenvolvimento sustentável;

- Objetivo 15. Proteger, recuperar e promover o uso sustentável dos ecossistemas terrestres, gerir de forma sustentável as florestas, combater a desertificação, deter e reverter a degradação da terra e deter a perda de biodiversidade;

- Objetivo 16. Promover sociedades pacíficas e inclusivas para o desenvolvimento sustentável, proporcionar o acesso à justiça para todos e construir instituições eficazes, responsáveis e inclusivas em todos os níveis;

- Objetivo 17. Fortalecer os meios de implementação e revitalizar a parceria global para o desenvolvimento sustentável.

Sartori et al. (2014) argumentam que o desenvolvimento sustentável é alavanca para atingimento da sustentabilidade em si, definida como a "capacidade de um sistema humano, natural ou misto para resistir ou se adaptar à mudança endógena ou exógena por tempo indeterminado". Tal pensamento é corroborado por Orsioli e Nobre (2016), que atestam que desenvolvimento sustentável e sustentabilidade têm as mesmas bases conceituais, mas diferem em suas definições. Enquanto a sustentabilidade é o lugar onde se pretende chegar, o desenvolvimento sustentável é o caminho a ser percorrido. 
Para Feil e Schreiber (2017), sustentabilidade consiste na capacidade do sistema global em manter sua qualidade em níveis próximos ou superior à média histórica, e que depende de três tipos de interesses que compreendem os aspectos econômico, ambiental e social. É baseada em um equilíbrio e sem prejuízos para as partes envolvidas, com a preocupação com a qualidade da interação entre os sistemas ambiental e humano.

SACHS (2008, p. 15) definiu cinco dimensões da sustentabilidade, em uma visão mais ampla buscando efetivar ações e metas para o tema, que são: Sustentabilidade social, Sustentabilidade econômica, Sustentabilidade ecológica, Sustentabilidade espacial e Sustentabilidade cultural. Apesar da disposição dos cincos elementos, pouco ainda se vê na literatura acadêmica de forma mais profunda. Silva, Alves e Volkmer (2014) sustentam que a maioria das referências sobre o desenvolvimento sustentável se referem a práticas de gestão organizacional e o "esverdeamento do capitalismo", como por exemplo o mercado de carbono e ferramentas para a manutenção da atual lógica de lucro máximo. No entanto, algumas poucas ações começam a surgir, mesmo que esparsas, mas ainda sem grandes contribuições para alterar o pensamento dominante e realizar mudanças estruturais.

Sartori et al. (2014) sinalizam que poucos trabalhos acadêmicos vão ao encontro da proatividade necessária à sustentabilidade como interação de processos dinâmicos, envolvendo sistemas industriais, sociais, naturais e incluindo fluxos de informações, bens materiais e resíduos. Por ser um tema ainda emergente, com uma grande variedade de assuntos relacionados, a sustentabilidade é tema crescente nas publicações e ainda carece de pesquisa aplicadas e que tragam resultados práticos e concretos.

\section{3.}

\section{Triple Bottom Line e sustentabilidade nas organizações}

Diante de todo o cenário em prol da sustentabilidade, as empresas se viram compelidas a atender às pressões externas e passaram a incorporar a sustentabilidade em suas governanças corporativas. A partir disso, as corporações começam a se pautar em aspectos éticos e com comprometimento das empresas com seus acionistas, comunidade onde atua e com a sociedade. Dessa forma, o papel da empresa não se limita apenas a gerar lucro máximo para acionistas, ou a prestar serviços ou produzir bens em condições eficientes, mas gerar riqueza para a sociedade de forma mais ampla (BENITES, POLO, 2013). 
Ainda segundo Benites e Polo (2013), as questões ambientais começam a não se limitar apenas no atendimento às legislações, mas trata-se de uma questão de sobrevivência empresarial e de competitividade. Cada vez mais os consumidores estão valorizando questões sociais e ambientais, e identificar estratégias corporativas que tratem dessas preocupações pode trazer vantagens competitivas e desempenho superior.

No entanto, Pacheco Júnior et al. (2011) comentam que nem sempre as práticas de sustentabilidade se expandem além dos contatos diretos das empresas, como em casos de promoção da imagem ou atendimento à legislações e regulações. Em um cenário em que a produção ainda é considerada como único fator gerador de riqueza, uma nova abordagem dinâmica, multidisciplinar e centrada no Homem é necessária, onde o papel de cada um não se limita mais a ações de autopromoção, mas em propiciar o desenvolvimento comum.

Elkington (2001) conceituou o termo "Triple Bottom Line" referente ao tripé da sustentabilidade: dimensões ambiental, social e econômica, e reforçou o redirecionamento das empresas para mudanças no âmbito empresarial, chamando a atenção para fatores do desenvolvimento sustentável. Ao incorporar a sustentabilidade em suas ações, as empresas devem adotar estratégias e formas de condução e gestão em consonância com todos os valores. Tal demanda gera a possibilidade de inovações em processos e modelos de negócios (ORSIOLLI, NOBRE, 2016).

Assim, a discussão do Triple Bottom Line se baseia nos três pilares: (a) Econômico, com empreendimentos economicamente viáveis; (b) Ambiental, com respeito ao meio ambiente e em atividades responsáveis e, (c) Social, com o estabelecimento de medidas justas para todas as partes envolvidas, Governo e comunidade (ARAÚJO, 2006), conforme pode ser observado na Figura 2: 


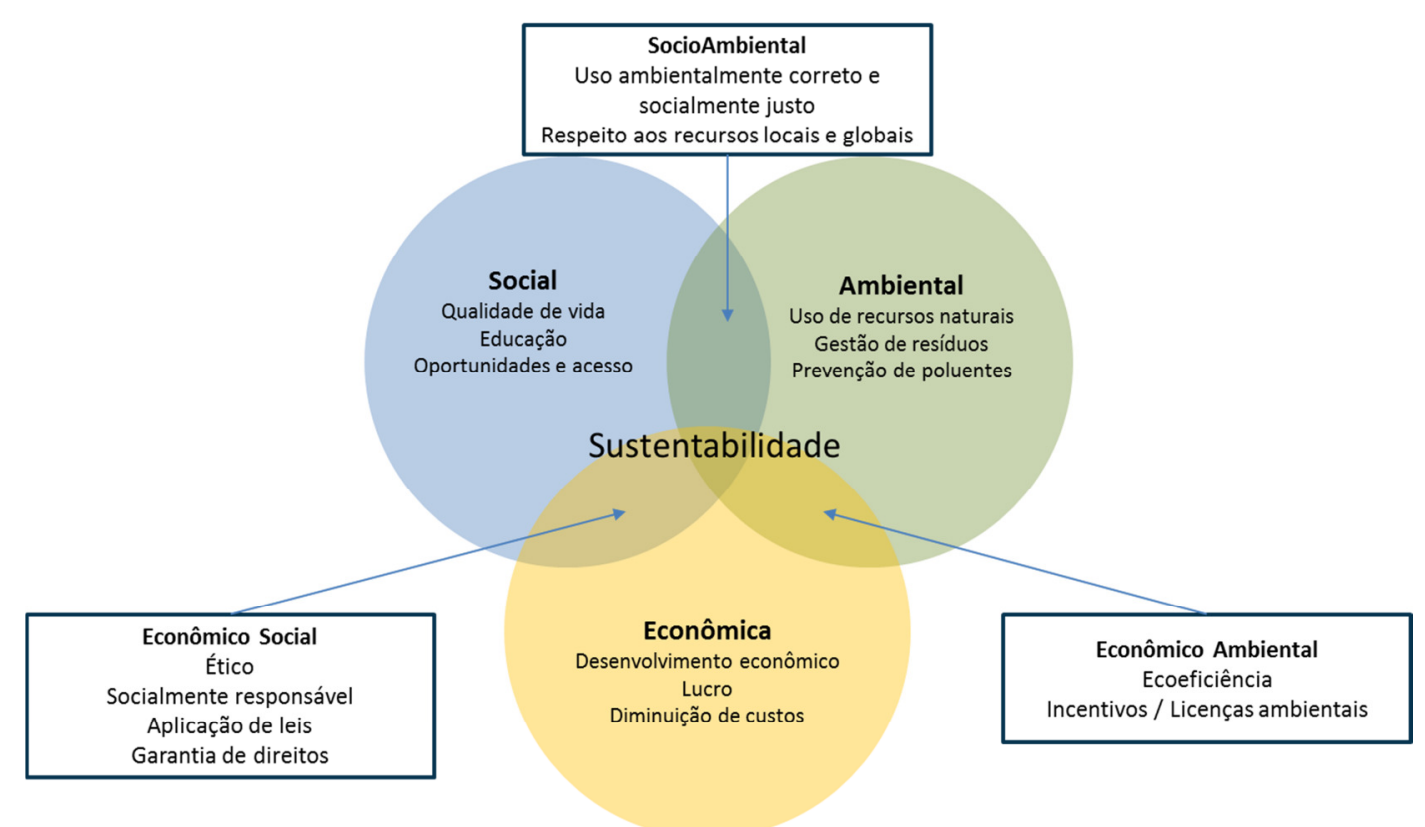

Figura 2: Triple Bottom Line

Fonte: Adaptado de University of Michigan Sustainability Assessment, 2002

Oliveira et al. (2012) ressaltam que está em discussão a inclusão de mais um pilar no conceito de Triple Bottom Line: o pilar cultural. No entanto, este pilar ainda não foi totalmente incorporado pelas organizações e são necessários estudos mais aprofundados para melhor entendimento de como este pilar pode influenciar o modelo.

Como um dos reflexos do processo de ampliação das preocupações ambientais, surgiu nas empresas o discurso da responsabilidade social corporativa (RSC), atentando-se para fatores de ordem social e ambiental, como demonstrar alto nível de transparência e integridade e estar comprometidas com o bem-estar social da comunidade. As empresas enxergaram oportunidades em meio a crises ambientais e sociais, e utilizam o tema para justificar a manutenção do crescimento (LARA, OLIVEIRA, 2017).

Segundo o Conselho Empresarial Mundial para o Desenvolvimento Sustentável, citada na obra de Melo Neto e Froes (1999, p. 87), "Responsabilidade Social Corporativa é o comprometimento permanente dos empresários de adotar um comportamento ético e contribuir para o desenvolvimento econômico, melhorando simultaneamente a qualidade de vida de seus empregados e de suas famílias, da comunidade local e da sociedade como um todo". Para Silva (2014), a RSC pode ser entendida como um valor integrado à estratégia, onde se procura alinhar os processos organizacionais com conhecimentos e habilidades pessoais, a partir da incorporação de aspectos sociais no processo em si e nos produtos. 
No Brasil, o Instituto Ethos de Empresas e Responsabilidade Social, criado em 1998 com a missão de mobilizar, sensibilizar e ajudar as empresas a gerir seus negócios de forma socialmente responsável, tornando-as parceiras na construção de uma sociedade justa e sustentável, reconhece a Responsabilidade Social Empresarial (RSE) como forma de tornar a empresa parceira e corresponsável pelo desenvolvimento social. Segundo o Instituto, a empresa socialmente responsável é aquela que possui a capacidade de ouvir os interesses das diferentes partes (acionistas, funcionários, prestadores de serviço, fornecedores, consumidores, comunidade, governo e meio ambiente) e conseguir incorporá-los ao planejamento e estratégia de suas atividades, buscando atender as demandas de todos, não apenas dos acionistas ou proprietários, mas também dos demais integrantes da cadeia produtiva como fornecedores, colaboradores, clientes (ETHOS, 2007).

Nessa lógica, as empresas que discursam a RSC têm melhor imagem e tendem a receber maiores investimentos (LARA, OLIVEIRA, 2017). Assim, as empresas não deixariam de incluir o lucro como objetivo, porém, ao invés de priorizar a maximização de lucros de curto prazo, elas deveriam buscar lucros de longo prazo, obedecer às leis e regulamentações, considerar o impacto nãomercadológico de suas decisões e procurar maneiras de melhorar a sociedade por uma atuação orientada para a Responsabilidade Social Empresarial (ETHOS, 2007).

Desde a década de 1980, foram criados fundos de investimentos para negócios mais limpos com menor impacto ambiental e para setores tecnológicos promissores. A possibilidade de ganhos de lucros em fundos específicos chamou a atenção do setor, até que em 1999, a Dow Jones instituiu um índice de sustentabilidade, o Dow Jones Sustainability Indexes (DJSI), baseado em princípios do Triple Bottom Line. Em 2001, foi lançado o FTSE4Good, índice de sustentabilidade da Bolsa de Valores de Londres e logo em seguida, outro índice semelhante foi lançado na Bolsa de Joanesburgo (LARA, OLIVEIRA, 2017). No Brasil, em 2005 foi criado o Índice de Sustentabilidade Empresarial (ISE) pela BM\&FBOVESPA (Bolsa de Mercadorias e Futuros e Bolsa de Valores de São Paulo) com o objetivo de estimular o desenvolvimento sustentável e boas práticas da responsabilidade socioambiental de empresas, uma vez que sustentabilidade não deve ser vista apenas como uma iniciativa ambiental, mas sim como parte da estratégia corporativa (BENITES, POLO, 2013). 
Outro padrão de prestação e contas bastante utilizado no meio empresarial é o Global Reporting Initiative (GRI), que tem por objetivo auxiliar empresas e partes interessadas no entendimento dos papéis e responsabilidades da organização ao alcance do desenvolvimento sustentável, além de auxiliar como ferramenta de comunicação, melhorando a qualidade de relatórios e indicadores. Além de abordar as dimensões do Triple Bottom Line, orienta as metas para a sustentabilidade e propõe, por exemplo, atrelar essas metas ao sistema de remuneração da companhia (DELAI, TAKAHASHI, 2008).

No entanto, mesmo com as orientações e promoção dos benefícios do desenvolvimento sustentável ainda existe um impasse na aplicação dos conceitos de sustentabilidade na gestão das organizações. A situação carece de literatura ou material de referência que traduzam as demandas da sociedade, explícitas e implícitas, em estratégias de ação e que apontem o caminho para as soluções através de um debate multidisciplinar que aborde as diversas esferas de ação de empreendimentos (PACHECO JUNIOR et al., 2011).

A gestão ambiental das empresas pode ser orientada a partir de três paradigmas: incremental, com ações reativas e apenas focadas na redução dos impactos; adaptativa, onde busca-se orientar o desenho do negócio e seus fluxos operativos adaptados ao meio dinâmico em que estão inseridos; radical, que tem como princípio a consciência das organizações sobre os problemas sociais e ambientais, como degradação e falta de acesso justo a recursos, poluição, fundamentado que as atuais formas de produção e consumo contribuem para esse cenário (RAUFFLET, 2006 apud JACOBI et al., 2011).

Para Trigo et al. (2015), a visão de negócios que norteou os empreendimentos até hoje foi a cartesiana, fragmentada e não integradora. De acordo com os autores, começa uma transição para um olhar holístico, mais complexo, com interações e relacionamentos de todos que compõem o ambiente de negócios. No entanto, apesar do movimento existente, o conhecimento teórico para essa mudança dos negócios precisa ser suportado pela academia, que ainda precisa preencher lacunas de conhecimento para a formação de um profissional consciente. Neste sentido, a formação deve focar na educação de indivíduos críticos e capazes de focar na sustentabilidade, para que sejam capazes de promover mudanças de comportamentos e atitudes inseridos em um ambiente coletivo. 


\section{4.}

\section{Ensino superior e sustentabilidade}

\subsection{1.}

\section{Educação superior no Brasil}

A educação é um direito de todos e consta na Constituição Federal do Brasil, sendo um dever do Estado e da família em garantir este direito (BRASIL, 1988). A Lei 9.394 de 20 de dezembro de 1996 - Lei de Diretrizes e Bases da Educação (LDB), baseada no princípio do direito universal à educação para todos, abrange os processos educacionais formativos que se desenvolvem na vida familiar, no trabalho, na convivência humana, nas instituições de ensino e pesquisa, nos movimentos sociais e organizações da sociedade civil e nas manifestações culturais. Determina que a educação escolar deverá vincular-se ao mundo do trabalho e à prática social, que a educação é dever da família e do Estado de modo que o ensino seja aplicado para o pleno desenvolvimento do educando, para que possa exercer a cidadania e esteja qualificado para o trabalho. Ainda segundo a Lei 9.394, a educação escolar compõe-se em: i) educação básica (que engloba a educação infantil, ensino fundamental e ensino médio); ii) educação superior (BRASIL, 2006).

De acordo com o Ministério da Educação (2016), existem 2.407 Instituições de Ensino Superior (IES) no Brasil, segmentadas em diferentes tipos de credenciamento: Faculdades, Centros Universitários, Institutos Federais e Universidades, conforme Tabela 1. Percebe-se que a maioria das IES são Faculdades, seguidas por Universidades e por Centros Universitários. Ainda de acordo com o MEC (2016), as diferenças entre os tipos de credenciamento de instituições se dão pela estrutura e atividades oferecidas pela IES, além de atributos que conferem o status de cada uma.

\begin{tabular}{cc}
\hline Instituições & Quantidade \\
\hline Universidade & 197 \\
\hline Centro Universitário & 166 \\
\hline Faculdades & 2.004 \\
\hline Institutos Federais & 40 \\
\hline Total & $\mathbf{2 . 4 0 7}$ \\
\hline
\end{tabular}

Tabela 1: Distribuições das IES por tipo no Brasil. Fonte: MEC, 2016 
De acordo com o Instituto Nacional de Estudos e Pesquisas Educacionais Anísio Teixeira - INEP (2008), as instituições podem ser públicas (mantidas e administradas pelo Poder Público, nas esferas federal, estadual ou municipal) e privadas, (mantidas e administradas por pessoas físicas ou jurídicas de direito privado), com ou sem fins lucrativos. Os cursos superiores no Brasil são dos tipos: cursos sequenciais, com até dois anos de duração, cursos de graduação, a maioria com quatro anos de duração, cursos de formação tecnológica, com dois ou três anos de duração, e cursos com cinco ou seis anos.

Segundo a LDB, a educação no ensino superior tem oito finalidades: i) estimular a criação cultural e o desenvolvimento do espírito científico e do pensamento reflexivo; ii) formar profissionais aptos para o exercício profissional e que contribuam para o desenvolvimento da sociedade; iii) incentivar o trabalho de pesquisa e investigação científica para desenvolver o entendimento do homem e do meio em que vive; iv) promover e atuar pro ativamente na divulgação de conhecimentos e saberes; v) suscitar o desejo permanente de aperfeiçoamento cultural e profissional; vi) estimular o conhecimento dos problemas do mundo presente, prestar serviços especializados à comunidade e estabelecer com esta uma relação de reciprocidade; vi) promover a extensão, aberta à participação da população, visando à difusão das conquistas e benefícios gerados na instituição; viii) atuar em favor da universalização e do aprimoramento da educação básica, mediante a formação e a capacitação de profissionais, a realização de pesquisas pedagógicas e o desenvolvimento de atividades de extensão que aproximem os dois níveis escolares (BRASIL, 2006, p. 14 e 15).

O relatório "Mapeamento da Educação Ambiental em instituições brasileiras de Educação Superior" (RUPEA, 2005; BRASIL, 2007) aponta que as IES são um dos principais locais de geração de conhecimento e têm a responsabilidade de fomentar a participação cidadã na sociedade, ao atuarem como espaços educadores incorporando em suas políticas e serviços as demandas sociais latentes. As IES representam um importante espaço de reflexão, formação e difusão de saberes para o desenvolvimento sustentável, já que têm como missão a educação profissional e a formação de educadores, influenciando os atores envolvidos para o estabelecimento de sociedades mais justas, solidárias e ambientalmente sustentáveis. 
Segundo Marcomin e Silva (2009), o relatório procurou mapear iniciativas socioambientais convidando 64 instituições para responder a um questionário sobre aspectos da sustentabilidade. Ao todo, 22 universidades, públicas e privadas em 11 estados, contribuíram para o estudo e os resultados mostraram que a maioria das iniciativas observadas são de docentes ou pesquisadores, e poucas ações derivam de políticas institucionais ou dos gestores das IES (MARCOMIN, SILVA, 2009).

Os problemas da educação no Brasil, segundo Lima e Khan (2011) são vários, como gestão ineficiente e desigual, falta de visão estratégica, cultura escolar elitista, má qualidade do ensino, interesses corporativistas e despreparo dos professores. A formação escolar é um processo cumulativo, e uma má qualidade e desempenho ineficiente do ensino fundamental é refletido no ensino médio e posteriormente no ensino superior, com impactos na formação de novos profissionais e de professores. Os autores ainda apontam que muitas IES apresentam dificuldades de preparar professores para ensinar, e que muitos professores recém-formados do ensino superior não se sentem seguros ou capacitados para o ofício, não sabendo o que é e nem como ensinar (LIMA, KHAN, 2011). Para Jacobi et al. (2011), outro limitante é a falta de conhecimento e entendimento correto acerca do tema sustentabilidade, e assim, a abordagem necessita transcender os limites acadêmicos e passar a incorporar princípios de aprendizagem social, apoiados em grupos de interesses comuns que promovam as dimensões sustentáveis e suas interconexões.

\subsection{2.}

\section{Acordos da educação para o desenvolvimento sustentável}

De acordo com Tilbury (2011), a relação da educação com o desenvolvimento sustentável tem suas raízes em 1972 com a Conferência de Estocolmo, primeiro local em que se foi debatido o papel do ensino superior para um desenvolvimento sustentável. Em seguida, no ano de 1975, a Conferência de Belgrado estabeleceu que o ensino deveria ser multidisciplinar e contínuo, aplicado às diferenças regionais existentes. Em 1977, foi assinada a Declaração de Tbilisi na qual foi debatida que o processo educativo deve ser orientado para a resolução dos problemas relacionados ao meio ambiente, com enfoques interdisciplinares e de responsabilidade de todos. Para Tauchen e Brandli (2006), o período entre 1972 e 1992 (ECO92) foi marcado pela emergência das instituições e redes de trabalho para determinar e orientar o papel das IES neste paradigma da sustentabilidade. 
Em 1990, foi assinada a Declaração de Talloires, onde responsáveis por universidades de várias regiões do mundo se encontraram na França para debater os urgentes problemas ambientais, atestando a preocupação com a velocidade e escala sem precedentes da poluição e degradação ambiental. Tais problemas ambientais, segundo o documento, ameaçam a vida dos seres humanos e demais espécies do planeta, a integridade da terra e da biodiversidade, a segurança das nações e o futuro das gerações vindouras. No documento, as universidades constataram a necessidade urgente de ações para reverter as tendências ambientais e da importância do papel das IES na educação, pesquisa, políticas e troca de conhecimentos e informações para atingimento de metas sustentáveis, com apoio e mobilização de recursos internos e externos (TALLOIRES DECLARATION, 1990).

No ano seguinte, em 1991, foi assinada a Declaração de Halifax no Canadá, em que representantes de universidades do mundo expressaram que as soluções dos problemas ambientais só seriam atingidas a partir de uma cooperação global e reafirmaram a necessidade das universidades ensinarem e praticarem princípios sustentáveis (HALIFAX DECLARATION, 1991).

Em 1992, ocorreu a ECO92 no Rio de Janeiro, evento da ONU e que teve como produto a Agenda 21. Para Barbieri e Silva (2011), a questão do ensino é abordada em quase todos as áreas e programas da Agenda 21, e o capítulo 36 é inteiramente dedicado a este assunto, apresentando três áreas de programas: i) reorientação do ensino no sentido do desenvolvimento sustentável; ii) aumento da consciência pública; e iii) promoção do treinamento. Tanto no ensino formal quanto no informal, a necessidade de orientar o ensino para o desenvolvimento sustentável é condição fundamental para modificar comportamentos e atitudes em prol da consciência ambiental, inserindo novos valores, técnicas e comportamentos necessários para a responsabilidade socioambiental. Nesse sentido, o ensino sobre o meio ambiente, por ser transdisciplinar, deve estar integrado nas diversas disciplinas e levar em conta a dinâmica e constantes mudanças dos meios físico, biológico e social, além da necessidade de se empregar meios efetivos de comunicação. O documento ainda aponta a necessidade de se incluir no programa de empresas e escolas de comércio, indústria e agricultura temas relacionados ao desenvolvimento sustentável, de modo que as pessoas sejam capacitadas e treinadas neste novo paradigma (CONFERÊNCIA DAS NAÇÕES UNIDAS SOBRE MEIO AMBIENTE E DESENVOLVIMENTO, 1992, seções 36.3 a 36.5 apud BARBIERI, SILVA, 2011). 
Em 1993, na Universidade de Wales, Swansea, País de Gales, foi assinada a Declaração de Swansea, em que os participantes acordaram que as soluções para os problemas ambientais apenas serão eficazes com a participação de todos. As IES têm papel fundamental neste ínterim ao buscar melhores entendimentos do que é o desenvolvimento sustentável, utilizar os recursos da universidade para o desenvolvimento das soluções, buscar a cooperação com outros segmentos da sociedade e enfatizar a obrigação ética da geração atual para não comprometer as futuras gerações (KRAEMER, 2004).

Ainda em 1993, em Kyoto, Japão, cerca de noventa líderes universitários se reuniram para debater e adotar princípios e práticas para a sustentabilidade, em um compromisso das IES para se engajarem na utilização de recursos para o desenvolvimento sustentável, estimular as práticas internas, potencializar a capacidade de ensino e aprendizagem para melhor compreensão da ética ambiental e cooperar com demais setores da sociedade, na procura de medidas que alavanquem o atingimento da sustentabilidade (KRAEMER, 2004).

Em 1994, foi criado por Copernicus (CO-operation Programme in Europe for Research on Nature and Industry through Coordinated University Studies) a Carta Copernicus, programa interuniversitário de cooperação ao desenvolvimento ambiental, estabelecida pela associação das universidades europeias. $\mathrm{Na}$ carta estão expressos compromissos das instituições para a educação ambiental, no sentido mais amplo do termo e citados dez princípios para a ação, como ética ambiental, educação dos empregados das instituições, networking, transferência de tecnologia dentre outros. O programa visa a inserção e aplicação dos conceitos de sustentabilidade em toda a instituição, estimulando projetos interdisciplinares e o desenvolvimento de materiais pedagógicos (COPERNICUS, 1994).

Em outubro de 2001, a Declaração de Lüneburg, assinada durante conferência na Alemanha, obteve a adesão de mais de mil universidades e faculdades e foi um chamado para a ação para instituições do ensino superior, ONG's e outras partes interessadas. Para o ensino superior, as intenções expressas na carta sinalizaram para o contínuo melhoramento de materiais didáticos para refletir as últimas descobertas científicas acerca da sustentabilidade, reorientação dos professores para o desenvolvimento sustentável, educação para a sociedade através de projetos, disseminando a consciência para uma abordagem ecológica e social, promovendo interações com outras universidades e com a comunidade, dentre outros (LÜNEBURG DECLARATION, 2001). 
A Declaração de Barcelona, assinada em 2004, levantou aspectos relacionados à necessidade de entendimento e estudo do contexto em que vivemos e das interações entre os sistemas relacionados à sustentabilidade. Além disso, abordou o processo educacional atentando para a revisão de itens como o conteúdo dos cursos, as estratégias de aprendizagem, os métodos de pesquisa e capacitações de professores, e da necessidade da adequação institucional na redefinição da missão e da orientação em prol do desenvolvimento sustentável (BARCELONA DECLARATION, 2004).

Reforçando a necessidade de estímulo à sustentabilidade, a Década da Educação para o Desenvolvimento Sustentável (DEDS), de 2005 a 2014, foi declarada pela UNESCO com o objetivo de estimular mudanças de atitudes e comportamentos nas populações, já que as ações do homem têm impactos nos outros seres vivos e nos recursos do planeta o impõe responsabilidades para com a natureza como um todo (UNESCO, 2005).

Em consonância com a DEDS, em abril de 2005 foi realizada uma conferência em Gratz, Áustria, cujo objetivo era discutir o papel das universidades e outras instituições de ensino superior na transição social para o desenvolvimento sustentável, além de tratar do desenvolvimento de estratégias para maior abertura das universidades para a sociedade. $O$ documento aponta que as instituições devem desenvolver e implementar ações que permeiem a sustentabilidade como conceito fundamental em suas estratégias, em todas as suas funções - ensino, pesquisa, responsabilidade social interna e externa (GRAZ DECLARATION, 2005).

Em 2009, durante o G8 University Summit em Turim, Itália, foi assinada a Declaração de Torino de Educação e Pesquisa para o Desenvolvimento Sustentável e Responsável, em um evento que contou com a participação de representantes das principais instituições de ensino e pesquisa dos países membros do G8. A declaração relaciona princípios e ações de estratégias educacionais e de pesquisa, e aponta as universidades como criadoras de novos modelos sociais e econômicos de acordo com os princípios da sustentabilidade, com melhor planejamento e eficiência energética e com foco no ecossistema inteiro, considerando todas as interações do homem com o meio ambiente. $\mathrm{Na}$ Tabela 2 são listadas algumas das conferências sobre educação e desenvolvimento sustentável ocorridas, desde 1977 até 2009. 


\begin{tabular}{cl}
\hline Nome & Ano \\
\hline Declaração de Tbilisi & 1977 \\
\hline Declaração de Talloires & 1990 \\
\hline Declaração de Halifax & 1991 \\
\hline Agenda 21 & 1992 \\
\hline Declaração de Swansea & 1993 \\
\hline Declaração de Kyoto & 1993 \\
\hline Declaração de Lüneburg & 2001 \\
\hline Declaração de Barcelona & 2004 \\
\hline Declaração de Graz & 2005 \\
\hline Declaração de Turim & 2009
\end{tabular}

Tabela 2: Conferências sobre educação e desenvolvimento sustentável Fonte: Elaboração própria

O papel das escolas de negócios também é discutido na literatura já que estas atuam diretamente na formação de líderes e gestores. Preocupados em entender como as instituições atendem a questões sustentáveis, entre outubro de 2006 e julho de 2007 foi desenvolvido o PRME (Principles for Responsible Management Education), um esforço conjunto de universidades e acadêmicos para um chamado global para inserir na educação de negócios aspectos relativos a direitos humanos, trabalho, ética e meio ambiente. O PRME visa adaptar a educação em termos de currículo, pesquisas e metodologias de aprendizagem, e é constituído por seis princípios (PRME, 2007):

1. Desenvolver as capacidades de estudantes para que possam ser futuros geradores de valor sustentável para os negócios e sociedade como um todo e para trabalhar por uma economia global e inclusiva;

2. Incorporar nas atividades acadêmicas e curriculares os valores da responsabilidade social global, conforme disposto em iniciativas internacionais, como o Pacto Global das Nações Unidas;

3. Criar estruturas e arquiteturas educacionais, materiais, processos e condições para que sejam possíveis realizar experiências efetivas de aprendizagem para a liderança responsável;

4. Engajar em pesquisas conceituais e empíricas que tragam maior compreensão sobre o papel, dinâmica e impacto de corporações na criação de valor social ambiental e econômico; 
5. Interagir com gestores de empresas para ampliar o conhecimento dos desafios empresariais no atendimento a responsabilidades ambiental e social e explorar conjuntamente abordagens efetivas para responder a esses desafios;

6. Facilitar e apoiar o diálogo e debate de educadores, empresas, consumidores, mídia, organizações da sociedade civil e outros grupos de partes interessadas sobre questões críticas concernentes a responsabilidade social e sustentabilidade global.

Alcaraz e Thiruvattal (2010) comentam que o PRME também se apresenta como uma rede aprendizagem entre as instituições de ensino, e que de acordo com a política do PRME, as instituições signatárias devem elaborar relatórios a cada 18 meses de forma a compartilhar informações com o restante da rede, permitindo a aprendizagem a partir de exemplos de outras IES, além de representar um esforço de divulgação para o público e demais partes interessadas, como os alunos, nos impactos para o futuro imediato da humanidade.

\subsection{3.}

\section{Papel das universidades para a sustentabilidade}

As instituições de ensino são responsáveis pela propagação de conhecimento na sociedade, e têm papel fundamental na construção de sociedades sustentáveis, devendo criar modelos sustentáveis que possam servir de inspiração para outras organizações (TRIGO et al., 2014). Assim, segundo Clugston e Calder (2003) a universidade sustentável é aquela que auxilia os alunos na compreensão dos problemas ambientais e sociais, que os motiva para a procura de soluções ambientalmente sustentáveis e que diminuam as desigualdades e injustiças sociais.

Por possuírem posicionamento único na sociedade, instituições de ensino superior são importantes lugares de geração e transmissão de conhecimento, com a habilidade de articulação com líderes políticos, empresas e demais partes interessadas para promover soluções de longo prazo e com foco em agendas para uma mudança social. Para Cortese (2003), as IES têm o dever moral de atuar na formação de valores, habilidades e conhecimentos necessários para a criação de um futuro sustentável, já que têm liberdade acadêmica para desenvolver novas ideias, analisar os desafios da sociedade e engajar a comunidade para resolução de nossos problemas mais latentes. Ainda segundo 
o autor, o ensino superior deveria praticar de fato a sustentabilidade, integrando o conceito às atividades das IES, como na operação dos campi, no planejamento, suprimentos e investimentos, além do currículo e bases acadêmicas e pedagógicas.

Segundo Cortese (2003), existem quatro grandes categorias de como uma IES pode atuar para transição para a sustentabilidade, a saber: i) a educação superior pode modelar práticas sustentáveis para a sociedade, começando com ações locais; ii) a educação para os alunos para promoção de habilidades de integração, síntese, pensamento sistêmico e como lidar com problemas complexos que são requeridos pela sustentabilidade; iii) o estudo, pesquisa e análise de problemas reais para a sustentabilidade; iv) a educação superior pode promover a integração entre indivíduos e instituições, de forma que a IES atue como agente multidisciplinar e integrador com outras organizações da sociedade civil.

A transição para a sustentabilidade depende de cinco fatores, tanto internos quanto externos, para uma abordagem sistemática e revisando os desafios e oportunidades de cada contexto para sustentabilidade em que a IES esteja incluída. Os fatores são relacionados a: i) os desafios dominantes da sustentabilidade de cada região, considerando fatores sociais, tecnológicos e ambientais; ii) a estrutura financeira e de onde provém o dinheiro das instituições, se de fontes privada ou pública; iii) a organização e estrutura do sistema de ensino superior, como os currículos são construídos e do papel que a IES deve exercer; iv) o processo democrático, como são os direitos e meios de acesso ao ensino superior e da transparência e neutralidade do ensino superior; v) comunicação e interação com a sociedade, no gerenciamento e disseminação de informações com a comunidade acadêmica e outros atores não acadêmicos da sociedade (CORTESE, 2003).

Para Tomashow (2014), a sustentabilidade é um estilo de vida que deriva de princípios ecológicos, senso comum e respeito pela diversidade e complexidade do planeta Terra. $O$ ensino superior possui importante papel para a sustentabilidade pois cabe às instituições ensinar esse estilo de vida sustentável, formando novas gerações de líderes que compreendam as intrínsecas conexões entre economia e ecologia, lugar e planeta, o modo como vivemos e as consequências de nossos atos. 
Jacobi et al. (2011) apontam que as mudanças requeridas nas instituições são mais profundas do que apenas a alteração do currículo, mas deve-se também fundamentalmente ao contexto e na forma como se ensina e aprende. Os autores salientam que são necessárias alterações no conteúdo e processos educativos de toda a instituição, e apontam três desafios:

1. A fragmentação das ações e a visão pouco integrada do tema pelas instituições de ensino superior faz com que grande parte das IES direcionem suas ações e forças para iniciativas de "esverdeamento" do campus ou inserção pontual de conteúdos no currículo, permanecendo como organizações "que conhecem" em vez de organizações que "aprendem" (aquelas que aprendem a desenvolver novas habilidades e capacidades que proporcionam novas percepções, que, por sua vez, revolucionam crenças e opiniões) (JACOBI et al., 2011);

2. Resistência das IES por questões administrativas e por parte dos docentes, formados por uma visão disciplinar e não integralizada, com dificuldades de adoção de novas visões interdisciplinares e com abordagens mais práticas de aprendizagem (experiental learning) (JACOBI et al., 2011);

3. Necessidade de uma mudança mais profunda e duradoura, com a participação de toda a instituição nas mudanças em andamento, em colaboração com estratégias de aprendizagem. O desafio consiste na ampliação da visão de colaboração e inclusão da participação de todos os stakeholders, compromisso com iniciativas estratégicas de longo prazo, adaptabilidade, a importância contextual e a aprendizagem organizacional (JACOBI et al., 2011).

Pontes et al. (2015) reforçam este último desafio e pontuam que em muitos casos a sustentabilidade é entendida apenas como modismo ou somente ligada a questões ambientais. A falta de entendimento do tema é refletida também na alta direção das instituições já que questões relacionadas à sustentabilidade muitas vezes são negligenciadas e tratadas apenas como mais um processo administrativo, limitadas pelo crescimento econômico.

Segundo Marcomin e Silva (2009), uma gestão generativa, dinâmica e integradora é necessária para instituições de ensino superior, de modo que a união entre ensino, pesquisa, extensão e gestão permeie e promova mudanças efetivas de conceitos, hábitos e práticas de gestão nos diversos níveis, da reitoria à sala de aula, passando pelas áreas administrativas e funcionais. Dessa forma, uma nova maneira de se gerir faz-se necessária, diferente da administração tradicional clássica, burocrática, lenta, fragmentadora e herdeira de tempos imperiais. 
Como forma de melhorar os controles relacionados a questões ambientais, as instituições de ensino vêm adotando ações como a implementação de um Sistema de Gestão Ambiental (SGA) e obtenção de certificações como a ISO 14001, conforme citado por Tauchen e Bradli (2006). Os autores apontam que existem várias razões para implantação de um SGA, dentre elas a característica das IES de poderem ser comparadas a pequenos núcleos urbanos, com diversas atividades de ensino e referentes a operação de bares, restaurantes, entre outros. Um campus ainda precisa de infraestrutura básica com redes pluviais, de água e esgoto, saneamento básico, energia e vias de acesso.

No entanto, a dificuldade de mensuração da sustentabilidade ainda é um dos desafios da construção de futuras sociedades sustentáveis, e a criação de instrumentos e indicadores capazes de avaliar a efetividade das ações adotadas é parte da solução para guiar a ação e medir o progresso em rumo à sustentabilidade. Neste sentido, diversos autores (CLUGSTON, CALDER, 1999; TAUCHEN, BRANDLI, 2006; TRIGO, LIMA, OLIVEIRA, 2014; WARKEN, HENN, ROSA, 2014; FRANCO et al., 2015; DRAHEIN et al., 2015; PONTES et al., 2015; BEURON, MADRUGA, ÁVILA, 2016;) analisaram instituições de ensino sobre diferentes olhares de medição da sustentabilidade, desde a análise curricular de disciplinas que abordam a sustentabilidade, ações para o desenvolvimento sustentável ou a construção e implementação de indicadores ambientais e sociais nas atividades realizadas.

\subsection{4.}

\section{Educação para o desenvolvimento sustentável}

Segundo LANDIM (1997), o termo educação refere-se à prática e ao processo ensino-aprendizagem e todas as ferramentas que levam o aluno a aprender a aprender, criar, inovar, construir conhecimentos, a saber pensar e ser um participante ativo no seu próprio conhecimento. Para Freire (2003, p. 40), "A educação é sempre uma certa teoria do conhecimento posta em prática [...]", dado que o conhecimento é um processo que o homem executa e que tem como saídas a ação e a reflexão da realidade.

A educação superior para o desenvolvimento sustentável tem por objetivo habilitar as pessoas em adquirir e gerar conhecimento, mas também para que possam refletir sobre os efeitos e complexidades de comportamentos e decisões em um futuro orientado para a sustentabilidade. Dado o atual estado de desenvolvimento da sociedade, a educação deve habilitar indivíduos para a reflexão acerca de suas próprias ações e os impactos sociais e ambientais 
decorrentes delas, de forma a permitir uma ponderação crítica dos problemas de sustentabilidade existentes e para permitir inovações para resolução dos problemas de ordem econômica, ambiental, social e cultural. Assim, IES são atores chaves para o desenvolvimento sustentável por serem elos entre a geração de conhecimento e transferência para a sociedade, além da necessidade de fomentar em alunos, docentes e colaboradores internos o incentivo a práticas sustentáveis (RIECKMANN, 2010).

Para a UNESCO (2005), a educação para a sustentabilidade prescinde de que o desenvolvimento sustentável seja inserido de forma integral na instituição de ensino de forma transversal, com foco para valores, competências, conhecimentos e habilidades voltados para a integração das dimensões econômica, ambiental e social.

Palma et al. (2013) comentam que a educação para o desenvolvimento sustentável precisa abranger as dimensões cognitivas, afetivas e estéticas de forma inter-relacionada e não compartimentadas, de forma que a educação seja holística para que os indivíduos sejam capazes de criticar suas próprias ações e comportamentos. Ainda apontam a necessidade de se atualizar os objetivos e os conteúdos dos currículos para desenvolvimento de uma nova compreensão da sustentabilidade, revisando metodologias de ensino, aprendizagem e avaliação.

Para Pontes et al. (2015), na questão da educação para o desenvolvimento sustentável é observada uma tendência para destacar a necessidade de mudanças de atitudes e comportamentos individuais, ao invés de focar em processos políticos e econômicos. Assim, os autores apontam que a construção de uma educação ambiental complexa significa ir além da "sustentabilidade de mercado", fragmentário e reducionista, mas na capacidade ade aprender, criar e exercitar novas concepções e práticas de vida, de educação e convivência que respondam aos problemas existentes, para que indivíduos críticos possam efetivar mudanças nos meios que atuam.

Melo e Brunstein (2014) salientam que são priorizados aspectos relativos apenas a profissionalização para o mercado de trabalho e à eficiência, ao controle de qualidade e à competitividade, reproduzindo práticas já existentes, ao invés de questionar os pressupostos e modelos atuais em busca de novas práticas para a sustentabilidade. Ainda para os autores, a educação para o desenvolvimento sustentável só será implementada de fato se houver uma profunda revisão das teorias de gestão e a forma como compreendemos as organizações e os papéis que elas desempenham na sociedade. 
As competências-chave, segundo Wiek et al. (2011), podem ser definidas como as competências críticas e mais importantes para os esforços que requerem a sustentabilidade. Para Rieckmann (2010), as competências-chave podem ser entendidas como competências multifuncionais e independentes do contexto, particularmente cruciais para implementação de metas da sociedade em um framework específico (como a sustentabilidade) e com importância para todos os indivíduos. O autor ainda comenta que as competências-chave não devem ser estimuladas e desenvolvidas em detrimento de outras, mas que todas as competências devem ser atendidas.

Rieckmann (2010) lista doze competências-chave, e dentre essas, o autor elenca as competências para o pensamento sistêmico e manejo de complexidades, pensamento antecipado e pensamento crítico como as principais competências e mais relevantes no contexto da sustentabilidade. Ainda acrescenta que as universidades devem criar condições particulares de aprendizagem, de forma que os alunos possam melhorar suas competências para o entendimento da complexidade e os efeitos em longo prazo das ações tomadas hoje, assim como questionar suposições comuns (RIECKMANN, 2010).

Wiek et al. (2011) também discorrem sobre as competências-chave, apontando cinco que precisam estar integradas e alinhadas com a sustentabilidade para proporcionarem a pesquisa de soluções de problemas da sociedade. As cinco competências são:

$\checkmark$ Competência de pensamento sistêmico: habilidade para coletivamente analisar sistemas complexos através de diferentes domínios (sociedade, meio ambiente, economia, etc) e diferentes escalas (local para global) (WIEK et al., 2011);

$\checkmark$ Competência de antecipação: habilidade para coletivamente analisar, avaliar e desenhar futuros desejáveis relacionados com a resolução de problemas sustentáveis (WIEK et al., 2011);

$\checkmark$ Competência normativa: habilidade para coletivamente mapear, especificar, aplicar, reconciliar e negociar valores, princípios, objetivos e metas sustentáveis, de forma a analisar cenários e modelar visões para esses cenários (WIEK et al., 2011);

$\checkmark$ Competência estratégia: habilidade para coletivamente desenhar e implementar intervenções, transições e transformadoras estratégias de governança para a sustentabilidade (WIEK et al., 2011); 
$\checkmark$ Competência interpessoal: habilidade para, buscando participação ativa, motivar, habilitar e facilitar coletivamente pesquisas e soluções de problemas sustentáveis (WIEK et al., 2011).

Para Brunstein e Rodrigues (2014), o desenvolvimento de competências é fruto do sentido que se dá ao trabalho e o progresso nessa matéria depende do contexto e da forma em como conceber mudanças. Essas mudanças podem ser um refinamento na maneira de pensar, um aprimoramento nos olhares ou uma ruptura na concepção do trabalho, substituindo-a por outra. A maneira para se identificar as mudanças se dá através da reflexão, caracterizada como veículo para aumentar a consciência que se tem sobre nossos pré entendimentos e ganhar profundidade, em um processo contínuo e com sucessivas interpretações.

No entanto, embora a reflexão seja central ao processo de desenvolvimento da competência, ela não é enfatizada ou priorizada, já que nosso foco de atenção durante o trabalho se dirige para a performance, e não para a reflexão. Dessa forma, são necessários diálogos reflexivos para instigar os sujeitos a ampliar sua concepção do trabalho, partindo da premissa que um diálogo é bem-sucedido quando as partes atingem um entendimento partilhado sobre assunto, diferente da forma original que conheciam. Assim, o desenvolvimento de competências pressupõe análise das concepções que os sujeitos têm do trabalho e da capacidade de criticar, analisar e reconstruir conceitos e concepções, avançando para novos entendimentos (BRUNSTEIN, RODRIGUES, 2014).

\subsection{5.}

\section{Dimensões do desenvolvimento sustentável no ensino superior}

Müller-Christ et al. (2014) apontam que, as discussões ocorridas na 4th UNESCO Chair Conference on Higher Education for Sustainable Development (HESD), realizada em 2011 na University of Lüneburg, Alemanha, ocorreram sobre três áreas acerca do papel das IES para o desenvolvimento sustentável: campus, currículo e comunidade. Os autores sugerem que é preciso haver mudanças profundas para conectar as três áreas, de forma que aspectos como diálogo, cooperação, participação e abertura estejam presentes no desenvolvimento de uma nova universidade sustentável. 
Sobre o campus, Müller-Christ et al. (2014) mencionam que é preciso uma abordagem "mão na massa", com práticas que promovam a sustentabilidade e exemplos práticos, abertos a possibilidades de inovações e locais de pesquisas, e que não se limite aos muros da instituição, mas que promovam e transfiram conhecimentos através de interações e comunicação com a comunidade ao redor. O engajamento de alunos e docentes deve ser estimulado pelos gestores, que devem contribuir com o suporte e apoio necessários.

Tilbury (2011) concorda com a visão de Müller-Christ et al. (2014), ao citar o campus como um dos desafios da educação superior para a sustentabilidade. A autora sugere a modelagem de práticas sustentáveis nos campi como campo de experimentação e cita iniciativas existentes na América do Norte, Europa e Ásia.

Tomashow (2014) propõe nove elementos a serem considerados para a sustentabilidade do campus. Os elementos são separados em três grandes categorias, a saber: Infraestrutura (Energia, Materiais e Comida), Comunidade (Governança, Investimento e Bem-Estar) e Aprendizagem (Currículo, Interpretação e Estética). Cada elemento não deve ser entendido apenas como a palavra ou um checklist, mas sim como um grande constructo dinâmico e interrelacionado com o meio, em trocas contínuas e constantes.

Stephens et al. (2008) citam a importância de as universidades serem referências para a sociedade em práticas sustentáveis, e que a experimentação dessas atividades no Campus podem ser modelos para a sociedade em geral. Os autores ainda afirmam que todos aqueles que interagem com a universidade são influenciáveis por essas práticas, o que ajuda na disseminação e consciência.

Ao abordar a comunidade, Müller-Christ et al. (2014) sustentam que a universidade deve fortalecer os laços com os stakeholders, através da transformação da IES em locais de pontos de encontro para discussões e debates, engajamento dos alunos com os desafios do mundo real, de como atacar problemas que estejam a volta. É ressaltada também a importância de um critério de qualidade e formas de mensurar essa qualidade, para que as soluções transdisciplinares possam ser medidas.

Para Tilbury (2011), existe a necessidade da IES de fazer parcerias e estender o raio de suas ações para além dos muros da instituição, atendendo também a comunidade em que esteja inserida. Stephen et al. (2008) apontam a importância de a universidade atuar na integração de diferentes stakeholders de 
forma a fomentar a transdisciplinaridade do ensino, não apenas limitados a docentes, alunos e colaboradores internos.

Com relação ao currículo, a questão de como integrar a sustentabilidade ao currículo é abordada nas discussões sobre os processos de decisão para mudança da estrutura curricular, e das maneiras de se influenciar esse processo. Sobre como ofertar o ensino para a sustentabilidade para os alunos, MüllerChrist et al. (2014) citam a possibilidade da oferta de disciplinas eletivas e dos incentivos e capacitações para desenvolvimento profissional dos docentes, para permitir uma melhor compreensão e olhar sobre o tema.

Com relação à educação, Tilbury (2011) aborda questões relativas aos estudos já realizadas por outros pesquisadores, afirmando que são necessários mais estudos que abordem a interdisciplinaridade e os impactos das ações existentes, além de sinalizar a necessidade de pesquisas propositivas de ação, com alteração de caráter informativo para transformador.

Stephen et al. (2008) salientam que o currículo deveria ser construído para promover a sustentabilidade, de modo que emerja novas habilidades aos alunos, como capacidades de síntese, integração e apreciação de sistemas complexos. A educação e formação de novos indivíduos devem ultrapassar barreiras puramente técnicas e focar em cidadania e formação integral. No entanto, são tarefas que encontram resistência visto que muitos profissionais têm sua formação marcada por especializações e apresentam intenções contrárias à implementação de novos enfoques para o ensino (PALMA et al., 2013).

Uma das possibilidades de se efetivar mudanças no cenário da educação é através de novas metodologias, em lógicas de aprendizagem prática. Nesse sentido, Jacobi et al. (2011) apontam que a comunicação entre pessoas é ferramenta para potencializar interações que tragam novas abordagens de mobilização social para a sustentabilidade. Observa-se que o sistema educacional frequentemente trata o ensino como fenômeno individual e isolado das demais experiências da vida, e que comunidades práticas podem ser alternativas na promoção de atividades sustentáveis.

Os docentes frequentemente encontram-se desprovidos de competências de orientação ecológica e necessitam de formação que permita integrar o ensino em todas vertentes possíveis da universidade, integrando-o em um todo sinérgico, coerente e em prol da sustentabilidade. Assim, a educação deve não só formar cidadãos e responsáveis éticos e conscientes com o todo, mas o processo deve ser acompanhado de empenho, dedicação, ética, respeito e amor (MARCOMIN, SILVA, 2009). 


\section{3 \\ Metodologia}

Este capítulo está dividido em seis seções que informam, respectivamente, sobre o tipo de estudo realizado, sobre o universo do estudo e processos de amostragem empreendidos, sobre os critérios de seleção de sujeitos que compõem a amostra. Na sequência, informa-se sobre os processos de coleta de dados realizados e sua justificativa, sobre os procedimentos de tratamento dos dados coletados e, por fim, sobre as possíveis repercussões que as decisões sobre como realizar o estudo impuseram aos resultados assim obtidos.

\section{1.}

\section{Tipos de pesquisa}

O estudo se caracterizou por três fases distintas: ambientação, coleta de dados e análise.

A primeira fase, de ambientação, é definida pelo contato com os temas propostos do estudo, através de levantamento bibliográfico. Nesta primeira fase foram determinadas as questões que deveriam ser respondidas, e como os dados seriam coletados, além da determinação dos objetivos e metodologia de pesquisa.

Em seguida, a segunda fase de coleta de dados foi constituída pelo levantamento de dados e informações através de questionários, entrevistas em profundidade semiestruturadas e pesquisa documental.

A última fase do estudo foi a de análise, onde os resultados dos levantamentos e entrevistas foram estruturados e o posicionamento das instituições e as percepções dos atores que se relacionam com as mesmas são analisados, possibilitando cruzamento de dados. Para a realização desta fase, foi necessário consolidar todos os dados coletados e transcrever entrevistas, para chegar a uma conclusão sobre o tema estudado.

Na Figura 3 é possível observar a estrutura da pesquisa e todas as etapas percorridas pelo pesquisador para construção do estudo. 


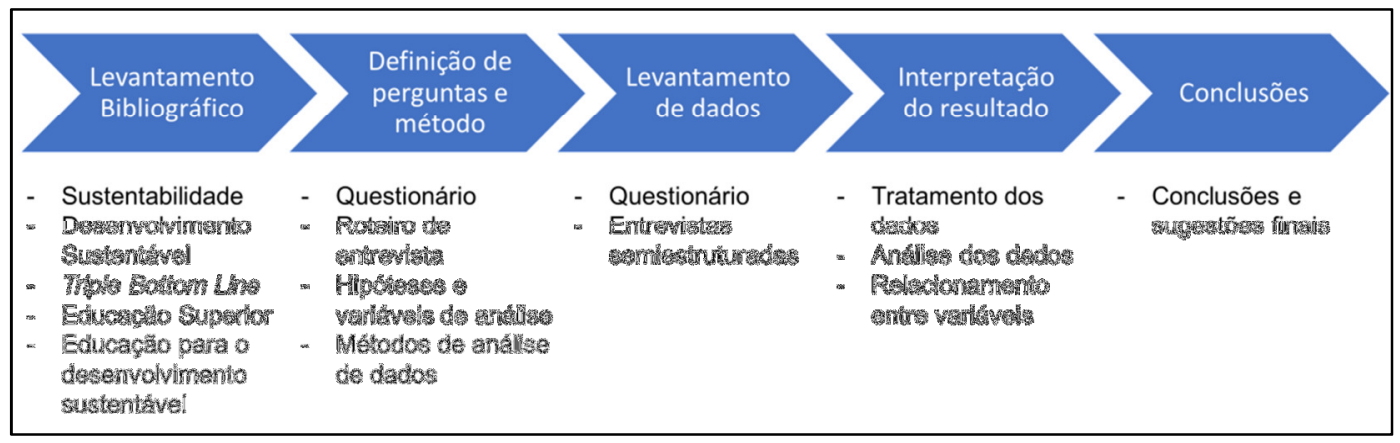

Figura 3: Estrutura da dissertação

Fonte: Elaboração própria

\subsection{1.}

\section{Quanto aos fins e aos meios}

Este estudo é do tipo misto, isto é, quantitativo e qualitativo. A pesquisa se utilizou de procedimentos de métodos mistos, isto é, utilizando entrevistas qualitativas para propósitos exploratórios e utilizando o método de survey com uma amostra ampla para análise quantitativa (CRESWELL, 2010, p. 39).

Quanto à estratégia quantitativa, a survey "é utilizada para proporcionar uma descrição quantitativa de tendências, atitudes ou opiniões de uma população, através do estudo de uma amostra dessa população" (CRESWELL, 2010, p. 38).

Ao abordar os atores que se relacionam com a instituição de ensino, é possível observar diferentes pontos de vistas sobre um tema que permeia não só a educação teórica, mas também prática, e assim, construir uma visão acerca de um fenômeno e expandir seus resultados.

Para este estudo, optou-se por investigar uma instituição de ensino superior privada sem fins lucrativos, localizada na cidade do Rio de Janeiro.

Para o levantamento de informações, optou-se pela aplicação de pesquisa de campo ou empírica com base em questionário online e entrevista com uma docente ligada a estratégias institucionais de sustentabilidade.

A pesquisa seguiu a estratégia incorporada, na qual os dados qualitativos e quantitativos foram coletados ao mesmo tempo, mas com o método qualitativo secundário ao quantitativo (CRESWELL, 2010), já que o aspecto qualitativo busca observar e registrar o posicionamento da universidade, ao passo que o método quantitativo mede a percepção de alunos e docentes.

A percepção de diferentes stakeholders acerca do que é desenvolvido nas universidades é tema encontrado em trabalhos de outros pesquisadores, com estudos conduzidos sobre a percepção de indivíduos acerca de diferentes tópicos do desenvolvimento sustentável em uma instituição de ensino superior, 
tanto com metodologias quantitativas, na aplicação de questionários e modelos para análise dos dados, qualitativos, baseado em observações e entrevistas, quanto mistos, em procedimentos que se utilizaram tanto de práticas quantitativas como qualitativas. Na Tabela 4 são elencados os estudos consultados neste trabalho: 
AUTORES

OBJETIVOS

KEINONEN, T., PALMBERG, I., KUKKONEN, J., YLI-PANULA, E., PERSSON, C., VILKONIS, R., 2016.

Captar a percepção de estudantes do ensino superior sobre questões ambientais e como as percepções são relacionadas com as percepções de cobertura da mídia.

Investigar a percepção de estudantes de engenharia de

SHEIKH, AZIZ, YUSOF, 2012. uma universidade da Malásia sobre o conhecimento deles acerca do desenvolvimento sustentável.

ABD-RAZAK, MUSTAGA, CHE-ANI, ABDULLAH, MOHD-NOR, 2011.

Identificar a percepção de estudantes sobre 0 planejamento para o desenvolvimento físico de Campi na Malásia.

\section{METODOLOGIA}

Aplicação de questionário via internet e pessoalmente com estudantes de 3 países, colhendo um total de 429 respostas durante 5 meses. Perguntas abertas e fechadas, abordando temas como a influência de questões ambientais no dia a dia, qual o principal problema ambiental, os temas mais e menos cobertos pela mídia, percepções sobre os problemas ambientais e soluções para o efeito estufa.

Utilização de ferramentas qualitativas como entrevistas e observações. Foram entrevistados 10 estudantes do primeiro ano de engenharia sobre temas como a educação recebida, percepção e definição do desenvolvimento sustentável, atividades do dia a dia e receptividade para as iniciativas do desenvolvimento sustentável.

O estudo utilizou-se de métodos qualitativos, como questionários, observação de comportamentos e estudos visuais, e quantitativos, com a aplicação de questionários. Foram obtidas 400 respostas, colhidas em quatro universidades da Malásia.

Criação e teste de um framework holístico para avaliar o nível de sustentabilidade das universidades, com aplicação online, via criação de um site e aberto por dois meses. O site foi visitado por 654 usuários distintos, mas com apenas 5 respostas completas sobre a avaliação da sustentabilidade.

Na pesquisa online com estudantes de graduação, mestrado e participantes do programa LLL, e entrevistas em profundidade com membros da universidade e diretores de escolas secundaristas. O questionário obteve 1.752 respostas válidas e 55 entrevistas realizadas.

Aplicação de questionário exploratório com 28 afirmativas para estudantes de uma universidade na Malásia. Afirmativas divididas em 4 construtos: alcance comunitário, comprometimento e monitoramento da sustentabilidade, lixo e energia e uso e planejamento do espaço físico.

Aplicação de questionário quantitativo, com um total de 484 respostas de estudantes de graduação. Foi realizada uma análise exploratória de fatores nas dimensões: meio ambiente, economia, sociedade e educação.

Aplicação de questionário exploratório para 60 estudantes de contabilidade e administração de empresas; entrevistas com 20 dos 60 estudantes para entendimento mais aprofundado. Os temas abordados foram: apoio de professores para ensino, satisfação com o conteúdo dos cursos para o desenvolvimento sustentável, utilidade do tema, entendimento holístico sobre o conceito de desenvolvimento sustentável. 


\begin{tabular}{|c|c|c|}
\hline $\begin{array}{l}\text { MICHALOS, A. } \\
\text { C., CREECH, H., } \\
\text { MCDONALD, C., } \\
\text { KAHLK, M. H., } \\
2009\end{array}$ & $\begin{array}{l}\text { Estabelecer uma estrutura de } \\
\text { monitoramento para avaliar } \\
\text { mudanças em níveis de } \\
\text { compreensão e } \\
\text { comportamentos nos } \\
\text { próximos anos entre os } \\
\text { jovens e a população em } \\
\text { geral. Com essa informação, } \\
\text { pretende-se ser capaz de } \\
\text { avaliar a eficácia de esforços } \\
\text { durante a DEDS (UN). }\end{array}$ & $\begin{array}{l}\text { Adaptação de framework da UNESCO em um } \\
\text { questionário composto de perguntas de } \\
\text { múltipla escolha sobre as perspectivas } \\
\text { socioculturais, ambientais e econômicas. O } \\
\text { questionário, composto de } 46 \text { perguntas, foi } \\
\text { enviado para cerca de } 5000 \text { pessoas e obteve } \\
506 \text { respostas. Foram aplicados testes } \\
\text { estatísticos para validar a amostra e } \\
\text { correlações. }\end{array}$ \\
\hline $\begin{array}{l}\text { LADEIRA, } \\
\text { SANTINI, } \\
\text { ARAUJO, } 2015 .\end{array}$ & $\begin{array}{l}\text { Descrever o processo de } \\
\text { validação de um instrumento } \\
\text { quantitativo específico para a } \\
\text { área de sustentabilidade, } \\
\text { aplicado em } 5 \text { IES do Rio } \\
\text { Grande do Sul, nas } \\
\text { dimensões Comunicação } \\
\text { Sustentável, Estratégias e } \\
\text { políticas sustentáveis, } \\
\text { Práticas de educação e } \\
\text { aprendizagem sustentáveis, } \\
\text { Práticas de criação de } \\
\text { conhecimento sustentável. }\end{array}$ & $\begin{array}{l}\text { Aplicação de questionário com } 763 \text { respostas } \\
\text { e utilização de análise fatorial como } \\
\text { ferramenta quantitativa para validar o } \\
\text { questionário, constituída nas etapas: } \\
\text { construção de questionário, coleta de dados, } \\
\text { análise fatorial entre blocos, análise fatorial no } \\
\text { bloco, fidedignidade. }\end{array}$ \\
\hline $\begin{array}{l}\text { HEEREN, } \\
\text { SINGH, } \\
\text { ZWICLE, } \\
\text { KOONTZ, } \\
\text { SLAGLE, } \\
\text { MCCREERY, } \\
2015 .\end{array}$ & $\begin{array}{l}\text { Examinar a relação de } \\
\text { conhecimento de } \\
\text { sustentabilidade com } \\
\text { comportamento pró- } \\
\text { ambiental, baseado na } \\
\text { percepção de que se } \\
\text { indivíduos conhecessem } \\
\text { melhor os conceitos, se } \\
\text { engajariam mais. Estudo } \\
\text { conduzido em uma grande } \\
\text { universidade dos Estados } \\
\text { Unidos. }\end{array}$ & $\begin{array}{l}\text { Aplicação da Teoria do Comportamento } \\
\text { Planejado (Theory of Planned Behaviour - } \\
\text { TPB), através de formulário online com mais } \\
\text { de } 500 \text { respostas, aplicado por } 6 \text { meses. A } \\
\text { ideia foi testar se a falta de conhecimento no } \\
\text { assunto gera baixo comportamento pró } \\
\text { sustentabilidade dos alunos. }\end{array}$ \\
\hline $\begin{array}{l}\text { WARDEN III, } \\
2012 .\end{array}$ & $\begin{array}{l}\text { Explorar a percepção de } \\
\text { alunos e membros de } 2 \\
\text { universidades americanas } \\
\text { das iniciativas de } \\
\text { sustentabilidade suas } \\
\text { instituições. }\end{array}$ & $\begin{array}{l}\text { Estudo quantitativo com levantamento de } \\
\text { dados via formulário online, abordando três } \\
\text { dimensões da sustentabilidade nas } \\
\text { instituições: gestão, educação e operações. } \\
\text { Dados analisados através da análise fatorial } \\
\text { para } 113 \text { respostas, obtidas em } 1 \text { mês de } \\
\text { questionário aberto. }\end{array}$ \\
\hline $\begin{array}{l}\text { MICANGELI, } \\
\text { NASO, } \\
\text { MICHELANGELI, } \\
\text { MATRISCIANO, } \\
\text { FARIOLI, } \\
\text { BELFIORE, } \\
2014 .\end{array}$ & $\begin{array}{l}\text { O artigo propõe e descreve } \\
\text { um novo método, chamado } \\
\text { L2A (listen-to-appraise), } \\
\text { concebido para melhorar o } \\
\text { compromisso de todos os } \\
\text { participantes envolvido em } \\
\text { um processo educacional } \\
\text { dedicado especificamente à } \\
\text { sustentabilidade e a } \\
\text { economia verde. }\end{array}$ & $\begin{array}{l}\text { Aplicação de questionário online nas } \\
\text { dimensões: sustentabilidade na educação, } \\
\text { aspectos da economia verde, intrapessoal, } \\
\text { interpessoal, pensamento lógico-matemático, } \\
\text { espacial, física, verbal e auto eficácia. Os } \\
\text { questionários enviados para alunos de uma } \\
\text { universidade na Itália e uma universidade em } \\
\text { Honduras, e para um grupo de trabalho em } \\
\text { energias sustentáveis da universidade italiana } \\
\text { Foi obtido um total de } 101 \text { respostas para o } \\
\text { questionário. }\end{array}$ \\
\hline
\end{tabular}

Tabela 4: Estudos sobre percepções em universidades

Fonte: Elaboração própria 


\section{2.}

\section{Universo e amostra}

O universo desta pesquisa são universidades no Rio de Janeiro com alguma atuação sustentável. $O$ foco de análise é uma instituição de ensino superior privada, sem fins lucrativos, com sede no Rio de Janeiro e com foco para atendimento das classes A e B, denominada de Instituição X.

No âmbito institucional, o grupo de sujeitos potenciais da pesquisa é composto por docentes e alunos, colaboradores, fornecedores e prestadores de serviços das instituições. O processo de amostragem limitou-se a alunos e docentes da instituição analisada.

\section{3.}

\section{Seleção dos sujeitos}

Com relação à parte qualitativa da pesquisa, o objetivo inicial da pesquisa era conduzir entrevistas com os representantes da instituição que pudessem responder sobre as ações da universidade nas dimensões campus, comunidade e educação. A responsável pelo processo de revisão das diretrizes de sustentabilidade da instituição foi contatada, mas não foi possível realizar a entrevista com ela dentro do tempo disponível. Assim, foi entrevistada em março de 2018 apenas uma docente com atuação destacada em projetos para a sustentabilidade na Universidade, além de algumas informações terem sido complementadas pelo orientador deste trabalho, também envolvido com projetos de sustentabilidade na instituição.

Para responder o questionário online, foram enviadas mensagens de email para os docentes de graduação e pós-graduação via grupos de e-mails da instituição. Foi solicitado que divulgassem o questionário em suas redes de contato, utilizando-se a colaboração para obter um maior número de respostas.

Foi utilizada também uma rede social para divulgação do questionário, com a postagem de mensagens em seis grupos de alunos da instituição, com alcance de mais de 50 mil usuários.

O questionário online ficou aberto de 29 de janeiro de 2018 a 28 de março de 2018, em um total de 68 dias, tendo sido realizados follow-ups com os dois grupos de respondentes. 


\section{4.}

\section{Procedimentos e instrumentos de coleta de dados}

A pesquisa qualitativa se utilizou de entrevistas em profundidade semiestruturadas para levantar o posicionamento institucional acerca das dimensões econômica, ambiental e social, aplicadas às dimensões do segmento educacional, como campus, currículo (educação) e comunidade.

A entrevista foi presencial, com a definição de um roteiro de sete perguntas sobre como a instituição percebe e atua para o desenvolvimento sustentável, conforme Tabela 5.

\begin{tabular}{|l|}
\hline Perguntas \\
\hline Qual é a definição de desenvolvimento sustentável para a instituição? \\
\hline Como a instituição atua na dimensão econômica? \\
\hline Como a instituição atua na dimensão social? \\
\hline Na sua opinião, a instituição atinge os objetivos sociais que se propõe a cumprir? \\
\hline Como a instituição atua na dimensão ambiental? \\
\hline Na sua opinião, a instituição atinge os objetivos ambientais que se propõe a cumprir? \\
\hline Como a instituição pratica as dimensões social e ambiental no campus? \\
\hline Como a instituição aplica os conceitos do desenvolvimento sustentável no currículo? \\
\hline $\begin{array}{l}\text { Como a instituição pratica os conceitos do desenvolvimento sustentável na relação com } \\
\text { a comunidade? }\end{array}$ \\
\hline Tabela 5: Perguntas do roteiro de entrevista para a instituição de ensino \\
Fonte: Elaboração própria
\end{tabular}

Com relação ao levantamento quantitativo, o pesquisador coletou dados a partir de questionário via internet sobre atitudes e comportamentos de docentes e alunos e a percepção das ações para o desenvolvimento sustentável da universidade. Inicialmente, o questionário foi passado para quatro pessoas como teste. Em média, os respondentes do teste responderam em aproximadamente 10 minutos e consideraram as perguntas de fácil entendimento, não reportando erros ou problemas de acesso ou compreensão. O questionário foi ainda revisto e aprimorado antes de sua aplicação.

O questionário é dividido em quatro partes. A primeira parte tem por objetivo identificar o respondente e é composta de seis perguntas sobre idade, sexo e relacionamento com a instituição (aluno, docente e colaborador), conforme Figura 4. 


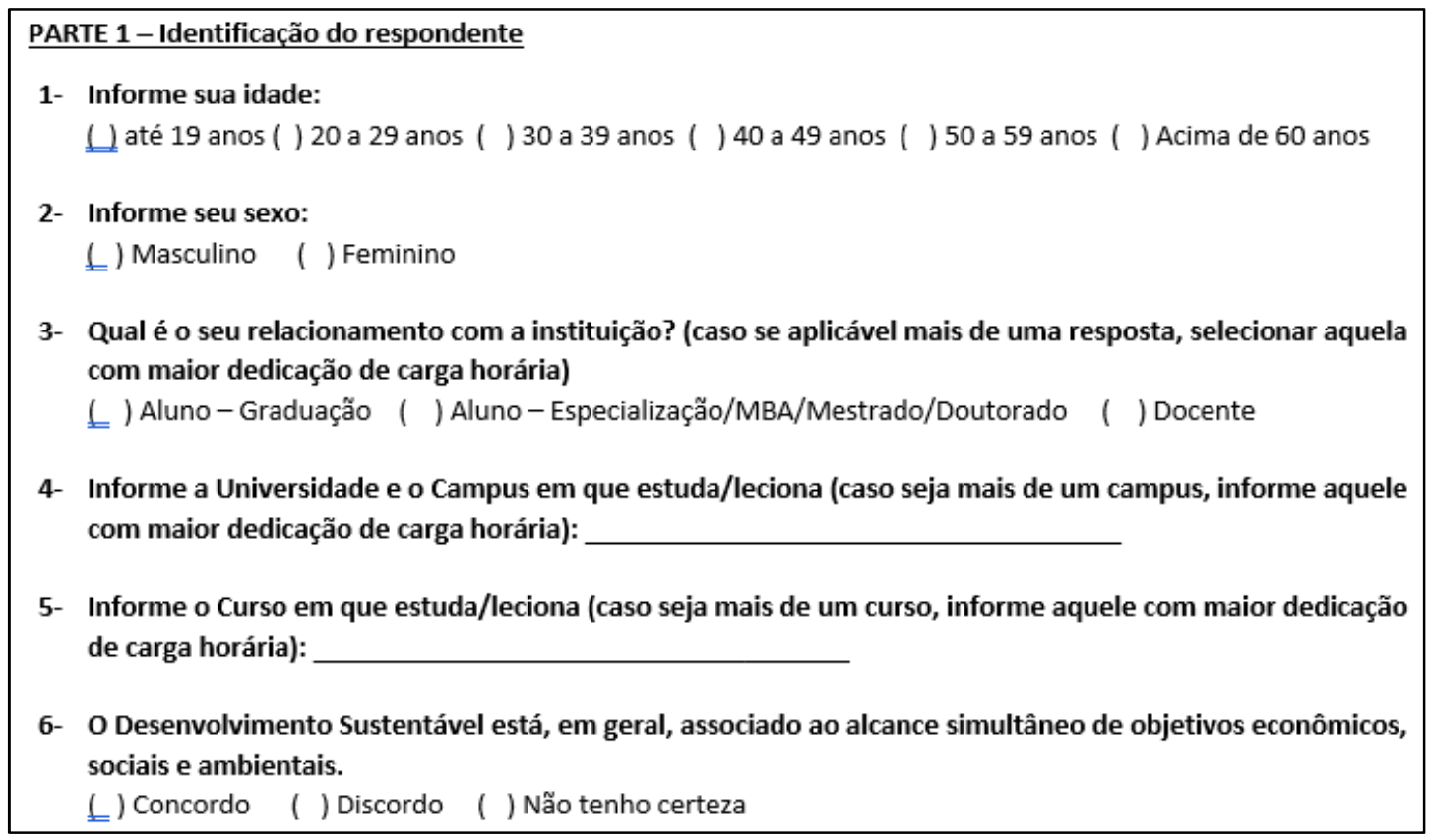

Figura 4: Parte 1 - Questionário

Fonte: Elaboração própria

Na segunda parte, são coletados os dados em onze perguntas referentes as atitudes e comportamentos dos indivíduos, nas dimensões Social, Ambiental, Econômica. $\mathrm{Na}$ terceira parte, são medidas as percepções das ações da universidade para o desenvolvimento sustentável, nas dimensões Campus, Comunidade, Educação e Promoção. As dimensões Campus, Comunidade e Educação são medidas conforme citado por Müller-Christ et al. (2014), que separam a atuação de uma universidade nessas três dimensões. A promoção também foi inicialmente incluída, pois essa dimensão, relativa à comunicação, é apontada por Rieckmann (2010) como uma das competências-chave necessárias para o desenvolvimento sustentável.

Assim, o questionário é composto também de cinco perguntas sobre o Campus, cinco sobre Comunidade, seis sobre Educação e duas sobre Promoção. As opções de respostas seguiram uma escala Likert de 1 a 5, com as seguintes alternativas: 1 - Discordo Totalmente, 2 - Discordo Parcialmente, 3 Nem concordo nem discordo, 4 - Concordo Parcialmente e 5 - Concordo Totalmente.

De acordo com Kardec (1978, apud GREGÓRIO, 2002), atitude se refere à intenção e o comportamento à ação. Assim, uma atitude pode ou não ser consumada, dependendo das circunstâncias e conjecturas. "Diz-se que uma atitude está formada quando esses componentes se encontram de tal maneira inter-relacionados que os sentimentos e tendências reativas específicas ficam coerentemente associadas com uma maneira particular de pensar em certas 
pessoas ou acontecimentos. Desenvolvemos nossas "atitudes" ao enfrentarmos e ajustarmo-nos ao meio social e, uma vez desenvolvidas, emprestam regularidade aos nossos modos de reagir e de facilitar o ajustamento social". (KARDEC, 1978, p. 7 apud GREGÓRIO, 2002). Paiva et al. (2017) apontam que, em seu estudo, existe um gap entre atitude e comportamento ambiental em uma universidade do Ceará. Os autores também citam outros trabalhos que se propuseram a analisar a distância entre atitudes e comportamentos, salientando que este assunto está em plena discussão na academia.

$\mathrm{Na}$ quarta parte do questionário são identificados dois quesitos: a satisfação e a participação dos respondentes. A Satisfação é medida em três perguntas com cinco opções de resposta, em uma escala Likert de 1 a 5, com as seguintes alternativas: 1 - Totalmente Insatisfeito, 2 -Parcialmente Insatisfeito, 3 - Nem Satisfeito Nem Insatisfeito, 4 -Parcialmente Satisfeito e 5 -Totalmente Satisfeito. A Participação é medida em três perguntas, duas de múltipla escolha (uma de resposta categórica e a outra em escala Likert) e uma de resposta livre.

$\mathrm{Na}$ Tabela 6, é possível verificar as perguntas relativas às partes 2, 3 e 4 do questionário e os blocos correspondentes, de acordo com cada dimensão avaliada.

\begin{tabular}{|c|c|c|}
\hline Variável & Pergunta & Referência \\
\hline Atitude1 & $\begin{array}{l}\text { O ensino de princípios de } \\
\text { sustentabilidade deve ser integrado ao } \\
\text { currículo em todas as disciplinas e em } \\
\text { todos os níveis de escolaridade. }\end{array}$ & $\begin{array}{l}\text { MICHALOS, A. C., CREECH, H., } \\
\text { MCDONALD, C., KAHLK, M. H., } \\
2009\end{array}$ \\
\hline Atitude2 & $\begin{array}{l}\text { A educação da cidadania é um } \\
\text { componente importante para o alcance } \\
\text { do desenvolvimento sustentável. }\end{array}$ & $\begin{array}{l}\text { MICHALOS, A. C., CREECH, H., } \\
\text { MCDONALD, C., KAHLK, M. H., } \\
2009\end{array}$ \\
\hline Atitude3 & $\begin{array}{l}\text { Iniciativas que busquem uma distribuição } \\
\text { mais igualitária de renda contribuem para } \\
\text { a solução dos problemas sociais. }\end{array}$ & $\begin{array}{l}\text { MICHALOS, A. C., CREECH, H., } \\
\text { MCDONALD, C., KAHLK, M. H., } \\
2009\end{array}$ \\
\hline Atitude4 & $\begin{array}{l}\text { A indústria deveria desencorajar o uso } \\
\text { de produtos e embalagens descartáveis. }\end{array}$ & $\begin{array}{l}\text { MICHALOS, A. C., CREECH, H., } \\
\text { MCDONALD, C., KAHLK, M. H., } \\
2009\end{array}$ \\
\hline Atitude5 & $\begin{array}{l}\text { Precisamos de leis e normas reguladoras } \\
\text { mais rígidas para proteger o meio } \\
\text { ambiente }\end{array}$ & $\begin{array}{l}\text { MICHALOS, A. C., CREECH, H., } \\
\text { MCDONALD, C., KAHLK, M. H., } \\
2009\end{array}$ \\
\hline Atitude6 & $\begin{array}{l}\text { O desenvolvimento sustentável não será } \\
\text { possível até que as nações mais ricas } \\
\text { parem de explorar os trabalhadores e os } \\
\text { recursos naturais dos países mais } \\
\text { pobres. }\end{array}$ & $\begin{array}{l}\text { MICHALOS, A. C., CREECH, H., } \\
\text { MCDONALD, C., KAHLK, M. H., } \\
2009\end{array}$ \\
\hline Comportamento1 & $\begin{array}{l}\text { Ajudo a resolver problemas sociais por } \\
\text { meio de trabalho social voluntário ou } \\
\text { doações a entidades de caridade. }\end{array}$ & $\begin{array}{l}\text { MICHALOS, A. C., CREECH, H., } \\
\text { MCDONALD, C., KAHLK, M. H., } \\
2009\end{array}$ \\
\hline
\end{tabular}




\begin{tabular}{|c|c|c|}
\hline Comportamento2 & $\begin{array}{l}\text { No transporte público, cedo meu lugar às } \\
\text { pessoas com necessidades especiais } \\
\text { (idosos, gestantes, etc). }\end{array}$ & PEREIRA, A. S., 2013 \\
\hline Comportamento3 & $\begin{array}{l}\text { Faço coleta seletiva em casa separando } \\
\text { o lixo reciclável do não reciclável. }\end{array}$ & $\begin{array}{l}\text { MICHALOS, A. C., CREECH, H., } \\
\text { MCDONALD, C., KAHLK, M. H., } \\
2009\end{array}$ \\
\hline Comportamento 4 & $\begin{array}{l}\text { Quando vou ao mercado, levo uma } \\
\text { sacola retornável para não usar sacolas } \\
\text { plásticas. }\end{array}$ & Própria \\
\hline Comportamento5 & $\begin{array}{l}\text { Compro prioritariamente de empresas } \\
\text { que pratiquem ações voltadas para a } \\
\text { redução da pobreza. }\end{array}$ & $\begin{array}{l}\text { MICHALOS, A. C., CREECH, H., } \\
\text { MCDONALD, C., KAHLK, M. H., } \\
2009\end{array}$ \\
\hline Campus1 & $\begin{array}{l}\text { A universidade possui ações } \\
\text { permanentes de coleta seletiva e } \\
\text { tratamento adequado de seus resíduos. }\end{array}$ & $\begin{array}{l}\text { ABD-RAZAK, M.Z., MUSTAFA, } \\
\text { N.K.F., CHE-ANI A.I., ABDULLAH, } \\
\text { N.A.G., MOHD-NOR, M.F.I., } 2011\end{array}$ \\
\hline Campus2 & $\begin{array}{l}\text { A universidade incentiva práticas de } \\
\text { consumo consciente de água e energia. }\end{array}$ & $\begin{array}{l}\text { ABD-RAZAK, M.Z., MUSTAFA, } \\
\text { N.K.F., CHE-ANI A.I., ABDULLAH, } \\
\text { N.A.G., MOHD-NOR, M.F.I., } 2011\end{array}$ \\
\hline Campus3 & $\begin{array}{l}\text { A universidade tem ações para atender } \\
\text { os portadores de necessidades especiais } \\
\text { (acessibilidade, no campus, oferta de } \\
\text { empregos para portadores de } \\
\text { deficiências, idosos, etc.). }\end{array}$ & $\begin{array}{l}\text { ABD-RAZAK, M.Z., MUSTAFA, } \\
\text { N.K.F., CHE-ANI A.I., ABDULLAH, } \\
\text { N.A.G., MOHD-NOR, M.F.I., } 2011\end{array}$ \\
\hline Campus4 & $\begin{array}{l}\text { A universidade promove um ambiente } \\
\text { propício à diversidade (religiosa, étnica, } \\
\text { cultural, ideológica, de gênero, etc.). }\end{array}$ & $\begin{array}{l}\text { MÜLLER-CHRIST, G., } \\
\text { STERLING, S. VAN DAM- } \\
\text { MIERAS, R., ADOMBENT, M., } \\
\text { FISCHER, D., RIECKMANN, M., } \\
2014\end{array}$ \\
\hline Campus5 & $\begin{array}{l}\text { A universidade realiza investimentos de } \\
\text { forma sistemática para tornar o Campus } \\
\text { mais sustentável }\end{array}$ & WARDEN, Kenneth Ray III, 2012 \\
\hline Comunidade1 & $\begin{array}{l}\text { A universidade participa de atividades } \\
\text { que promovem o desenvolvimento social } \\
\text { da comunidade em que está inserida. }\end{array}$ & $\begin{array}{l}\text { MÜLLER-CHRIST, G., } \\
\text { STERLING, S. VAN DAM- } \\
\text { MIERAS, R., ADOMBENT, M., } \\
\text { FISCHER, D., RIECKMANN, M., } \\
2014\end{array}$ \\
\hline Comunidade2 & $\begin{array}{l}\text { A universidade participa de atividades } \\
\text { voltadas para a solução de questões } \\
\text { ambientais da comunidade em que está } \\
\text { inserida. }\end{array}$ & NEJATI, M., NEJATI, M., 2013 \\
\hline Comunidade3 & $\begin{array}{l}\text { A universidade promove ou incentiva a } \\
\text { participação de seus professores, alunos } \\
\text { e funcionários em projetos sociais ou } \\
\text { ambientais junto à comunidade em que } \\
\text { está inserida. }\end{array}$ & NEJATI, M., NEJATI, M., 2013 \\
\hline Comunidade4 & $\begin{array}{l}\text { A universidade é aberta a sugestões e } \\
\text { críticas de professores, alunos, } \\
\text { funcionários e membros da comunidade } \\
\text { em que está inserida. }\end{array}$ & NEJATI, M., NEJATI, M., 2013 \\
\hline Comunidade5 & $\begin{array}{l}\text { A universidade realiza ações para } \\
\text { promover o desenvolvimento econômico } \\
\text { da comunidade em que está inserida. }\end{array}$ & $\begin{array}{l}\text { MÜLLER-CHRIST, G., } \\
\text { STERLING, S. VAN DAM- } \\
\text { MIERAS, R., ADOMBENT, M., } \\
\text { FISCHER, D., RIECKMANN, M., } \\
2014\end{array}$ \\
\hline
\end{tabular}




\begin{tabular}{|c|c|c|}
\hline Educação1 & $\begin{array}{l}\text { A universidade oferece em seu currículo } \\
\text { disciplinas que integram diferentes áreas } \\
\text { do conhecimento. }\end{array}$ & BIASUTTI, M., FRATE, S., 2017 \\
\hline Educação2 & $\begin{array}{l}\text { A universidade promove e incentiva a } \\
\text { reflexão sobre o seu papel e forma de } \\
\text { atuação na sociedade. }\end{array}$ & BIASUTTI, M., FRATE, S., 2017 \\
\hline Educação3 & $\begin{array}{l}\text { A universidade incentiva o pensamento } \\
\text { crítico voltado para o alcance da } \\
\text { sustentabilidade. }\end{array}$ & NEJATI, M., NEJATI, M., 2013 \\
\hline Educação4 & $\begin{array}{l}\text { A universidade oferece em seu currículo } \\
\text { uma quantidade adequada de disciplinas } \\
\text { que abordem o desenvolvimento } \\
\text { sustentável. }\end{array}$ & $\begin{array}{l}\text { LADEIRA, W. J., SANTINI, F. O., } \\
\text { ARAÚJO, C. F., } 2015\end{array}$ \\
\hline Educação5 & $\begin{array}{l}\text { A universidade oferece em seu currículo } \\
\text { atividades que permitam a prática dos } \\
\text { conceitos do desenvolvimento } \\
\text { sustentável. }\end{array}$ & NEJATI, M., NEJATI, M., 2013 \\
\hline Educação6 & $\begin{array}{l}\text { A universidade incentiva a pesquisa } \\
\text { sobre os temas que compõem o conceito } \\
\text { de desenvolvimento sustentável. }\end{array}$ & $\begin{array}{l}\text { LADEIRA, W. J., SANTINI, F. O., } \\
\text { ARAÚJO, C. F., } 2015\end{array}$ \\
\hline Promoção1 & $\begin{array}{l}\text { A universidade divulga frequentemente } \\
\text { material sobre questões relacionadas ao } \\
\text { desenvolvimento sustentável } \\
\text { (econômico, social e ambiental). }\end{array}$ & $\begin{array}{l}\text { MÜLLER-CHRIST, G., } \\
\text { STERLING, S. VAN DAM- } \\
\text { MIERAS, R., ADOMßENT, M., } \\
\text { FISCHER, D., RIECKMANN, M., } \\
2014\end{array}$ \\
\hline Promoção2 & $\begin{array}{l}\text { O conteúdo dos materiais divulgados } \\
\text { pela universidade contribui para uma } \\
\text { maior conscientização sobre o } \\
\text { desenvolvimento sustentável. }\end{array}$ & $\begin{array}{l}\text { MÜLLER-CHRIST, G., } \\
\text { STERLING, S. VAN DAM- } \\
\text { MIERAS, R., ADOMßENT, M., } \\
\text { FISCHER, D., RIECKMANN, M., } \\
2014\end{array}$ \\
\hline Satisfação1 & $\begin{array}{l}\text { Como você avalia sua satisfação com as } \\
\text { ações para o desenvolvimento } \\
\text { sustentável que a Universidade realiza } \\
\text { no Campus? }\end{array}$ & $\begin{array}{l}\text { MÜLLER-CHRIST, G., } \\
\text { STERLING, S. VAN DAM- } \\
\text { MIERAS, R., ADOMßENT, M., } \\
\text { FISCHER, D., RIECKMANN, M., } \\
2014\end{array}$ \\
\hline Satisfação2 & $\begin{array}{l}\text { Como você avalia sua satisfação com o } \\
\text { relacionamento que a Universidade } \\
\text { desenvolve com a comunidade? }\end{array}$ & $\begin{array}{l}\text { MÜLLER-CHRIST, G., } \\
\text { STERLING, S. VAN DAM- } \\
\text { MIERAS, R., ADOMßENT, M., } \\
\text { FISCHER, D., RIECKMANN, M., } \\
2014\end{array}$ \\
\hline Satisfação3 & $\begin{array}{l}\text { Como você avalia sua satisfação com a } \\
\text { educação para o desenvolvimento } \\
\text { sustentável da Universidade? }\end{array}$ & $\begin{array}{l}\text { MÜLLER-CHRIST, G., } \\
\text { STERLING, S. VAN DAM- } \\
\text { MIERAS, R., ADOMßENT, M., } \\
\text { FISCHER, D., RIECKMANN, M., } \\
2014\end{array}$ \\
\hline Participação1 & $\begin{array}{l}\text { Você participa ou participou de alguma } \\
\text { atividade promovida pela universidade } \\
\text { relacionada ao desenvolvimento } \\
\text { sustentável? }\end{array}$ & Própria \\
\hline Participação2 & $\begin{array}{l}\text { Caso sua resposta tenha sido "Sim" para } \\
\text { o item anterior, cite a atividade mais } \\
\text { relevante. Caso tenha respondido "Não", } \\
\text { deixe esta pergunta em branco. }\end{array}$ & Própria \\
\hline Participação3 & $\begin{array}{l}\text { Estou disposto a participar de futuras } \\
\text { atividades para o desenvolvimento } \\
\text { sustentável promovidas pela } \\
\text { Universidade? }\end{array}$ & Própria \\
\hline
\end{tabular}

Tabela 6: Perguntas do questionário

Fonte: Elaboração própria 


\section{5.}

\section{Tratamento dos dados}

A metodologia usada para os testes e análises dos dados deste trabalho seguiu o fluxo de atividades conforme a Figura 5. Nela são descritas as etapas de tratamento e análise dos dados quantitativos obtidos por meio do questionário online.

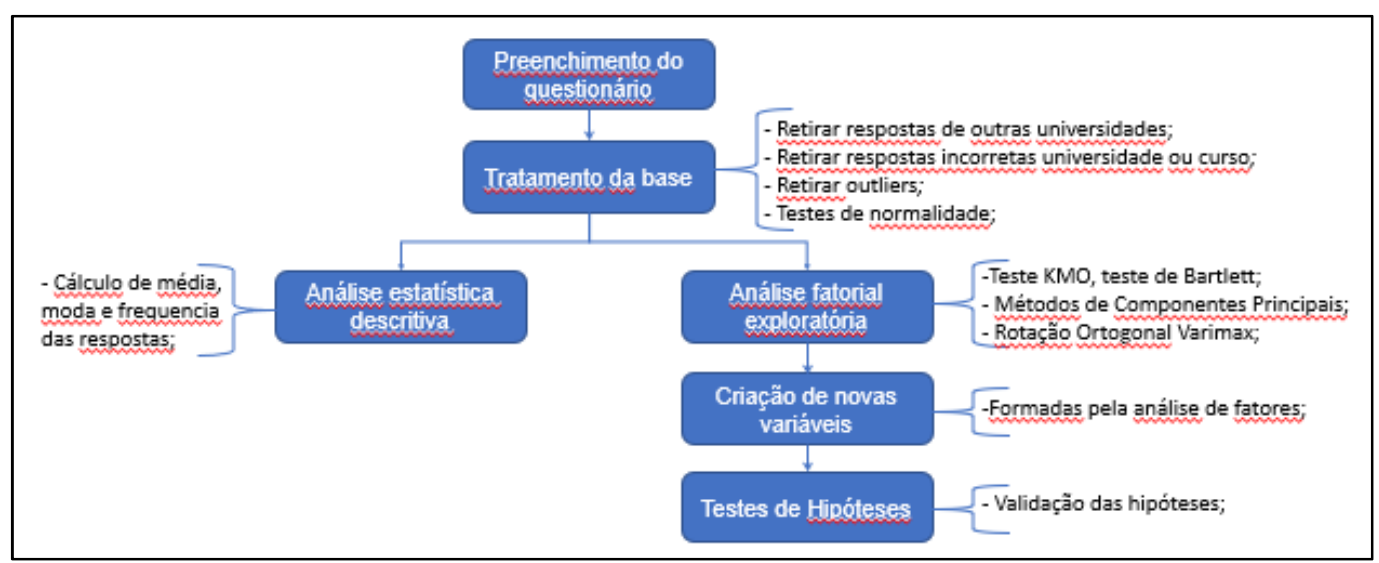

Figura 5: Metodologia

Fonte: Elaboração própria

Com o preenchimento do questionário pelos respondentes, os dados foram gravados em uma planilha online. $O$ primeiro tratamento dado a base foi a análise de todos os nomes de cursos e categorizados afim de poder distinguir o curso com mais respondentes, independente da relação com a universidade.

Foram obtidas 919 respostas no questionário, das quais 46 não tiveram o campo Universidade/Campus preenchido corretamente (outras universidades, campus fora do âmbito da pesquisa ou em branco), e foram retiradas da base. Em seguida, foram identificadas as respostas com preenchimento errado dos nomes de cursos, identificando 17 respostas, que também foram retiradas da base, totalizando 856 respostas válidas.

A base de dados da Instituição $X$ foi carregada no software IBM SPSS Statistics 22 para executar as análises estatísticas da base de dados. Em seguida, foi executado o teste do gráfico de caixas nas variáveis com respostas na escala Likert, que permite identificar observações atípicas através de gráficos. Segundo Hair et al. (2005), as observações atípicas são aquelas que variam entre 1,0 e 1,5 quartis de distância da caixa, e as observações que estão a mais de 1,5 quartis, são as extremas. Neste estudo, foi identificada a frequência das respostas outliers (atípicas e extremas) por variável, e caso o valor fosse maior do que 1 , a resposta era excluída do questionário. Foram identificadas respostas 
atípicas e extremas, em um total de 106 respostas (casos) outliers totais. Analisadas a frequência dos outliers, foram identificadas 72 respostas únicas, ou seja, configurada como outliers em pelo menos uma das variáveis analisadas. Das 72 respostas, 23 apareciam em mais uma variável, sendo assim excluídas. Após o tratamento da base de dados, o resultante total de respostas válidas para a Instituição $X$ foi de 833 .

Em seguida, foram analisadas as respostas da questão que apresentava uma afirmação que refletia o conceito básico de Desenvolvimento Sustentável e solicitava ao respondente que afirmasse se concordava ou discordava dela. Dos 833 respondentes, 34 escolheram a opção "Discordo" e 41 a opção "Não tenho certeza". Diante do objetivo do trabalho de avaliar a percepção dos respondentes acerca do desenvolvimento sustentável, partiu-se da premissa que apenas os respondentes com resposta "Concordo" seriam avaliados. Assim, 75 respostas foram excluídas da base, resultando em um total de 758 respostas efetivamente utilizadas.

Para estimar a confiabilidade do questionário, foi realizada a Análise de Consistência Interna (Alpha de Cronbach), em que se considera adequados valores acima de 0,70 , muitos bons valores acima de 0,80 e excelentes valores acima de 0,90. Neste sentido, o resultado da pesquisa foi de 0,873 , valor considerado bom (boa confiabilidade), conforme Figura 6.

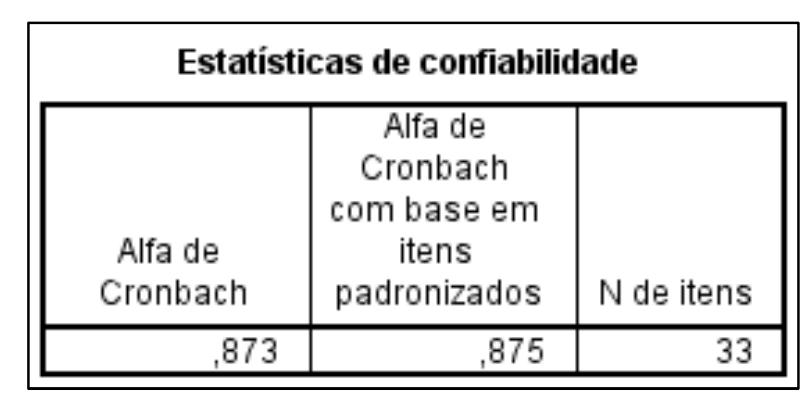

Figura 6: Teste de Alfa de Cronbach Fonte: Elaboração própria

Em seguida, foram aplicados testes de normalidade nas respostas. O resultado mostrou que nenhuma das variáveis em escala Likert apresenta distribuição normal, conforme consta no Anexo 1, já que obtiveram estatísticas D e W baixas respectivamente nos testes Kolmogorov-Smirnov e Shapiro-Wilk, com nível de significância igual a 0,000 nos dois testes, rejeitando-se assim a hipótese nula da normalidade (HAIR et al., 2005). Os testes de normalidade também foram segmentados por público, e os resultados mostram que nenhuma das variáveis possui distribuição normal para as amostras de alunos e docentes, conforme Anexo 1. 
Em seguida foi realizada uma análise fatorial exploratória para redução do número de variáveis a fim de facilitar tratamentos posteriores. Segundo Portela (2012), esta é uma técnica em que não se conhece a priori a estrutura fatorial existente entre as variáveis em observação, e por este motivo, atribui-se fatores para identificar as relações estruturais entre as variáveis que não são observáveis diretamente. Hair et al. (2005) sugerem que, para cada variável, deve haver, no mínimo, cinco observações. Neste estudo, o número mínimo de respostas seria de 165, e o obtido foi de 758 respostas para a Instituição X, uma média de 22,9 observações por variável, bem acima do limite proposto.

O Teste de Kaiser-Meyer-Olin testa a validade da análise fatorial, que compara as correlações simples com as correlações parciais observadas entre as variáveis, em que quanto mais perto o valor de 1 , melhor a validade da análise fatorial. Foi realizado também o teste de Esfericidade de Bartlett, com um $p$-value < 0.001, indicando que as variáveis estão correlacionadas significativamente (HAIR et al., 2005). Os testes foram conduzidos separadamente nas variáveis das dimensões Atitude, Comportamento, Campus, Comunidade e Educação.

Para se determinar o número de fatores a reter, foram utilizados os critérios de componentes principais nas variáveis de cada dimensão, seguida de uma rotação ortogonal utilizando o critério VARIMAX onde valores próximos a 1 indicam uma associação entre a variável e o fator, e valores próximos de 0 , apontam uma falta de associação (HAIR et al., 2005). Foi definido que apenas os valores acima de 0,60 seriam considerados e forçados os critérios para formar 3 fatores.

Como resultado da análise fatorial, para cada dimensão foram criadas três variáveis (AT1, AT2, AT3, CO1, CO2, CO3, CA1, CA2, CA3, CM1, CM2, CM3, ED1, ED2, ED3) consideradas neste estudo para os testes de hipótese. Adicionalmente, foram criadas variáveis baseadas nas médias das variáveis acima de cada dimensão com o objetivo de medir cada dimensão individualmente, que configurou na estrutura para os testes conforme a Figura 7 e explicação a seguir. 


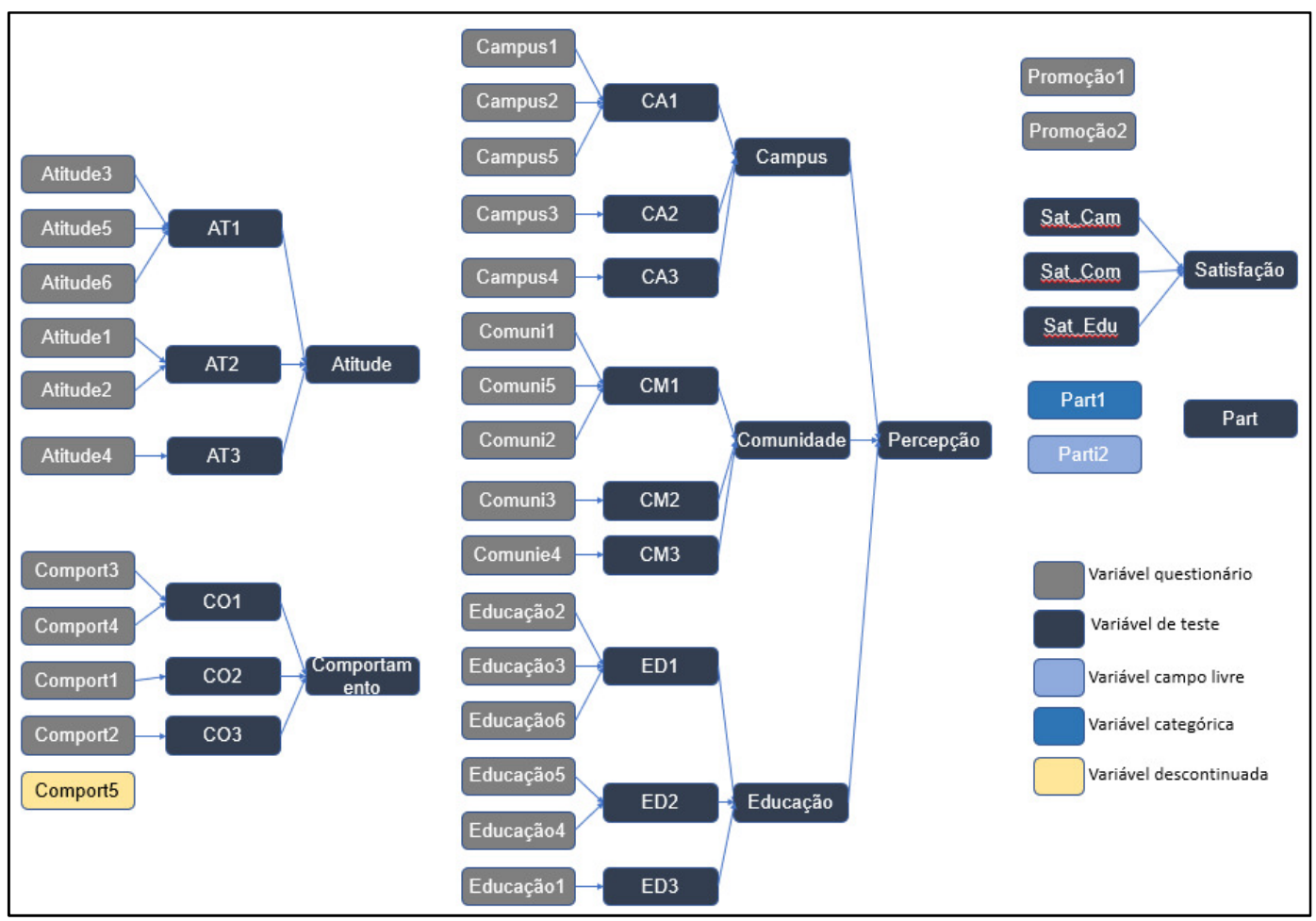

Figura 7: Variáveis do estudo

Fonte: Elaboração própria

A variável AT1 é resultante da média simples das variáveis Atitude3, Atitude5 e Atitude6. A variável AT2 é composta pela média das variáveis Atitude1 e Atitude2. A variável AT é composta pela variável Atitude4. A variável Atitude é a média de AT1, AT2 e AT3.

A variável CO1 é resultante da média de Comportamento3 e Comportamento4. A variável CO2 é composta pela variável Comportamento1 e Comportamento variável e CO3 é composta pela variável Comportamento2. A variável Comportamento5 foi descartada após análise fatorial. A variável Comportamento é a média de CO1, $\mathrm{CO} 2$ e CO3.

A variável CA é a média simples das variáveis Campus1, Campus2 e Campus5. A variável CA2 é a Campus3 e variável CA3 é a Campus4. A variável Campus é composta da média de CA1, CA2 e CA3.

A variável Comunidade é a média simples das variáveis Comunidade1, Comunidade2, Comunidade3, Comunidade4 e Comunidade5 e representa a percepção das ações da universidade com a comunidade.

A variável ED1 é a média simples das variáveis Educação2, Educação3 e Educação6. A variável ED2 é resultante da média simples das variáveis Educação4 e Educação5, e variável ED3 é a Educação1. A variável Educação é a média simples de ED1, ED2 e ED3. 
A variável Percepção é a média das variáveis Campus, Comunidade e Educação, e representa a percepção individual sobre as ações da universidade para o desenvolvimento sustentável.

Com relação a quarta parte do questionário, a variável Satisfação é composta pela média simples das variáveis Sat_Cam, Sat_Com e Sat_Edu, e representa a satisfação dos respondentes em relação as ações desenvolvidas pela universidade considerando as três dimensões estudadas conjuntamente (Campus, Comunidade e Educação). Por fim, a variável Part é a variável Participação3, que busca medir a intenção ou a propensão para participação futura em atividades para o desenvolvimento sustentável.

As variáveis relativas à dimensão Promoção foram descartadas dos testes de hipótese por não apresentaram variável de satisfação correspondente. A dimensão poderia ter sido aplicada a um nível de satisfação global, mas optouse por simplificar a análise.

A variável Participação1 mede se os respondentes já participaram de alguma atividade na universidade, e seria utilizada para verificar se respondentes que já participaram de ações estariam mais propensos a participar novamente, mas a análise não foi efetuada por limitações de tempo. A variável Participação2 (de resposta texto livre) foi utilizada para analisar respostas de alunos ou docentes que trabalhem institucionalmente com a sustentabilidade, 0 que poderia criar algum viés na pesquisa. Assim, ambas as variáveis também foram descartadas para os testes de hipóteses.

Todas as variáveis criadas foram submetidas ao teste de normalidade de Kolmogorov-Smirnov, que constatou que nenhuma delas apresenta distribuição normal, já que suas estatísticas baixas tiveram $p$-value $<0,05$ de significância, 0 que levou à rejeição de que a distribuição da amostra é normal (Hair et al., 2005), segundo testes realizados no SPSS, exibidos no Anexo 1.

Com base no modelo conceitual da pesquisa, previamente construído, foram elaboradas hipóteses como questões norteadoras do trabalho. As hipóteses testadas seguem abaixo, conforme Figura 8.

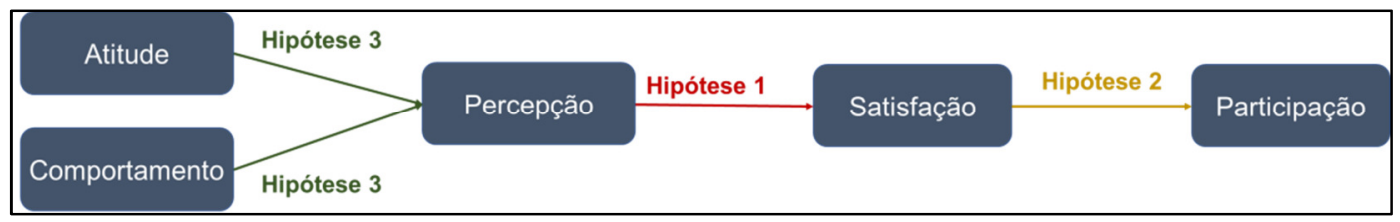

Figura 8: Modelo Conceitual e Hipóteses do estudo

Fonte: Elaboração própria 
$\checkmark$ Hipótese 1 - Docentes e alunos que percebem positivamente as ações da universidade nas dimensões Campus, Comunidade e Educação estão mais satisfeitos com a universidade nas respectivas dimensões do que aqueles que não percebem positivamente.

$\checkmark$ Hipótese 2 - Docentes e alunos satisfeitos com as ações de sustentabilidade da universidade são mais propensos a se envolver em atividades para o desenvolvimento sustentável do que aqueles indiferentes ou não satisfeitos.

$\checkmark$ Hipótese 3 - A percepção dos docentes e alunos sobre as ações para o desenvolvimento sustentável das universidades é influenciada pela sua atitude e/ou pelo seu comportamento mais gerais em relação à sustentabilidade.

Por critério do pesquisador, as variáveis que compõem a dimensão Percepção foram classificadas em três níveis, segundo os valores das respostas: Grupo3 - baixa ou negativa (1,0 a 2,9), Grupo2 - média (3,0 a 3,9) e Grupo1 alta ou positiva $(4,0$ a 5,0). O mesmo critério foi aplicado para as variáveis do constructo Satisfação (satisfação Campus, satisfação Comunidade e satisfação Educação) e para a variável Participação3. As variadas calculadas, criadas para análise do estudo, também foram classificadas segundo esse critério.

Para a realização dos testes de hipóteses, foram criadas variáveis de classificação dos níveis dos valores das variáveis Atitude, Comportamento, Campus, Comunidade, Educação, Percepção, constructo Satisfação e Participação. As variáveis_Nível classificam os valores segundo o critério de grupos, onde o valor 1 se refere ao Grupo1, 2 ao Grupo2 e 3 ao Grupo3.

Os testes das primeira e segunda hipóteses foram realizados através das análises de variância não-paramétricas, já que, além da amostra não apresentar distribuição normal, também foi verificada a violação do teste de Levene (sig < $0,05)$, onde o resultado apontou a falta de homogeneidade das variâncias entre as variáveis (Hair et al., 2005), o que impediria a aplicação dos testes paramétricos como ANOVA e MANOVA.

Foram realizadas tentativas de transformações matemáticas na base (SQRT, inverso, log, ARCSIN (SQRT)) para obter uma distribuição normal, mas os resultados ainda apresentaram inconsistências com relação à normalidade. Assim, foram conduzidos testes não-paramétricos de modo a testar as hipóteses. 
O primeiro teste conduzido foi a MANOVA não-paramétrica, que tem como base o Teste Kruskal-Wallis, executado para testar se as distribuições dos valores da variável dependente são iguais em diferentes populações (MAROCO, 2007). A estatística de teste segue conforme Figura 9 abaixo:

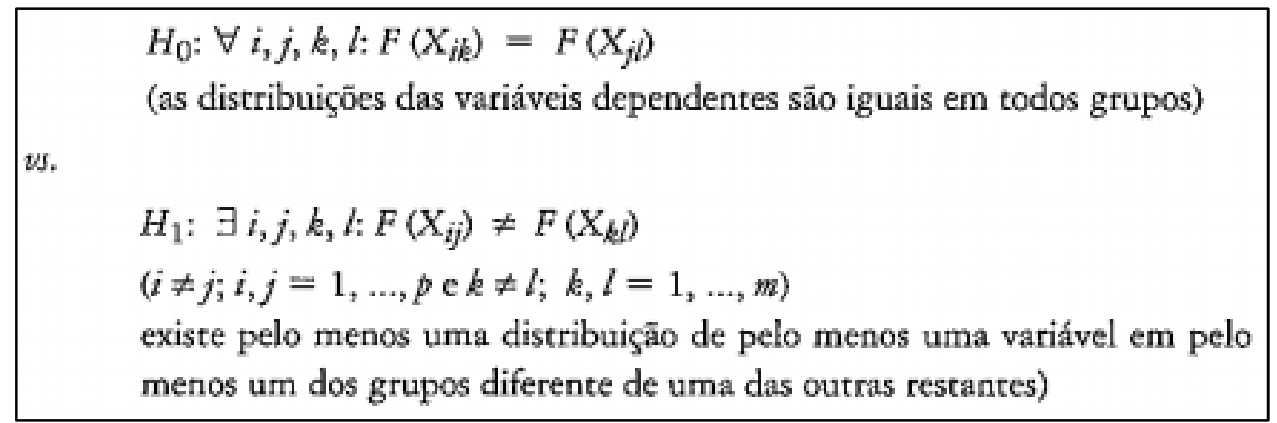

Figura 9: Estatística de Teste - MANOVA não-paramétrica Fonte: MAROCO, p.255, 2007

Segundo Maroco, (2007, p. 255):

"Os métodos não-paramétricos para designs multivariados são baseados nas ordens das observações, e, a partir das diferenças entre as médias das ordens e da matriz de covariância das ordens é possível calcular uma extensão multivariada da estatística de Kruskal-Wallis."

Com o auxílio do software SPSS, foram calculados os dados ordenados das variáveis analisadas para iniciar os testes do trabalho. Para o cálculo de $\mathrm{H}_{0}$, (ZWICK, 1985, p. 256 apud MAROCO, 2007) cita que “... esta estatística pode obter-se usando o traço de Pillai calculado com as ordens". O resultado é obtido através de uma MANOVA com os dados ranqueados como variável dependente e os níveis dos grupos como variável independente. Com o fator de Pillai obtido, é calculado o valor $p$-value $\mathrm{P}\left[\mathrm{X}_{\mathrm{p}(\mathrm{m}-1)}{ }^{2} \mathrm{x}^{2}\right]$, de modo a testar a hipótese nula $\mathrm{H}_{0}$ (as distribuições das variáveis dependentes são iguais em todos grupos). Como resultado do teste, rejeita-se $\mathrm{H}_{0}$ se $p$-value $\leq$ nível de significância $\alpha$.

Em seguida, para se observar as diferenças significativas, foi realizado o teste de Kruskal-Wallis e por fim, foi realizada a comparação múltipla de médias das ordens para as variáveis (MAROCO, 2007), usando Bonferroni, para verificação de médias das ordens dos grupos. A significância obtida via KruskalWallis das variáveis testa a não-diferença das distribuições das ordens e a ANOVA com Bonferroni garante a análise individual para cada fator, já que o teste compara ranqueando as médias entre as variáveis.

Para testar a primeira hipótese, foram seguidos os passos conforme descritos abaixo: 
1.1) Execução de uma MANOVA não-paramétrica, tendo como variáveis dependentes as variáveis de satisfação relativas às dimensões Campus, Comunidade e Educação, e como variáveis independentes, as variáveis classificadores de grupos CampusNível, ComunidadeNível e EducaçãoNível, que medem a percepção individual por dimensão (Grupo 1 - percepção alta ou positiva, com valor maior ou igual a 4; Grupo2 - percepção média, com valor entre 3 e 3,9; Grupo3 - percepção baixa, com valor menor do que 3).

1.2) Teste de Kruskal-Wallis para verificação das satisfações relacionadas ao Campus, à Comunidade e à Educação, em relação ao nível de percepção de cada dimensão.

2.1) Execução de uma MANOVA não-paramétrica, tendo como variáveis dependentes todas as variáveis relativas às dimensões Campus, Comunidade $\mathrm{e}$ Educação, e como variável independente a variável classificadora PercepçãoNível, que classifica a percepção geral (média das percepções do Campus, Comunidade e Educação) em três grupos: Grupo1 - percepção positiva; Grupo2 - percepção média; Grupo3 - percepção negativa).

2.2) Teste de Kruskal-Wallis para verificar a satisfação das dimensões e geral dentro dos grupos de percepção, e tendo como variável independente a PercepçãoNível.

A primeira etapa (passos 1.1 e 1.2) tem por objetivo analisar se as percepções são confirmadas individualmente por cada variável que compõe as dimensões, incluindo as suas respectivas satisfações. A segunda etapa (passos 2.1 e 2.2) analisa se a percepção geral é confirmada pelas variáveis criadas de cada dimensão, incluindo a satisfação geral.

Para testar a segunda hipótese, foram seguidos os passos conforme descritos abaixo:

1) Execução de uma MANOVA não-paramétrica, com variável dependente Part e as variáveis Sat_Cam, Sat_Com e Sat_Edu, e como variável independente, SatisfaçãoNível.

2) Execução de Teste Kruskal-Wallis para verificar as diferenças significativas observadas. 
O teste da terceira hipótese foi feito através de uma análise de regressão linear, que segundo Hair et al. (2005), consiste em uma técnica estatística para analisar a relação entre uma única variável dependente (critério) e uma ou mais variáveis independentes (preditoras). Para testar a terceira hipótese, foram seguidos os passos conforme descritos abaixo:

1) Execução de uma regressa linear múltipla, com variável dependente Percepção e com variáveis independentes, Atitude e Comportamento.

Por fim, após a realização dos testes de hipóteses, foi feita uma análise das respostas do questionário por meio de estatística descritiva, como média e frequência de respostas. Para consolidação das dimensões, foram criadas variáveis compostas das médias das variáveis de cada dimensão (Atitude, Comportamento, Campus, Comunidade, Educação, Promoção, Satisfação, Percepção). A análise foi realizada por público, se docente ou aluno.

\section{6.}

\section{Limitações do método}

A pesquisa se limitou a dissertar sobre as percepções de alunos e docentes de uma instituição de ensino da cidade do Rio de Janeiro. Também foram coletados dados de outra instituição de ensino, mas os mesmos não foram analisados por limitações de tempo e complexidade da base, ficando como sugestão para próximos trabalhos.

Não podemos afirmar que os resultados da pesquisa se aplicam a outras instituições de ensino, mas podemos supor que outros indivíduos em outras universidades e de classe social semelhante, tendem a ter atitudes e comportamentos semelhantes com os apresentados.

Neste estudo, não foram realizados testes não-paramétricos equivalentes ao teste t para garantir se as médias são iguais a determinado valor, conforme dados apontados na análise descritiva dos dados.

Por uma questão de pouco tempo disponível e por entender que as questões abordadas na pesquisa eram de maior domínio de docentes e alunos, a pesquisa não se estendeu aos demais stakeholders da universidade, tais como funcionários, prestadores de serviços ou fornecedores da instituição de ensino. As análises multivariadas não foram segmentadas por idade ou curso, e os testes de hipótese também não foram realizados por público, se docente ou aluno, decidindo-se deixar esta análise para uma etapa posterior à conclusão do mestrado. 


\section{4}

\section{Análise e interpretação dos resultados}

Este capítulo, organizado em duas seções apresenta e discute os principais resultados alcançados, discute suas implicações e produz sugestões sobre o problema de pesquisa previamente selecionado.

A primeira seção apresenta o resultado da entrevista em profundidade, em como a representante da instituição observa o desenvolvimento sustentável e as ações praticadas nas dimensões campus, comunidade e educação.

A segunda seção apresenta os resultados dos dados quantitativos. São analisadas as estatísticas descritivas de cada instituição, realizados os testes de hipótese para a Instituição $\mathrm{X}$ e discutidos seus resultados.

\section{1.}

\section{Análise dos dados qualitativos}

$\mathrm{Na}$ Instituição $\mathrm{X}$, foi entrevistada apenas uma docente da área de educação, responsável por alguns projetos e programas ambientais na universidade. A entrevista foi realizada em março de 2018 e as principais impressões, anotadas. A docente informou que, desde 2009, a universidade criou uma Agenda Ambiental para o endereçamento de questões ambientais dentro do âmbito universitário, com diretrizes e metas de curto, médio e longo prazo nos níveis de gestão, ensino e pesquisa na universidade. Tal posicionamento é incentivado pelo atual reitor da universidade, que desde 2011, é um grande apoiador das questões ambientais.

Ao apresentar o resultado da entrevista qualitativa para o orientador desta pesquisa, este forneceu explicações adicionais sobre a Agenda Ambiental, informando que, apesar do movimento da Agenda, as metas propostas não ficaram claramente ligadas a ações concretas nem a indicadores mensuráveis, e se limitaram apenas à dimensão ambiental, sem levar em consideração a vertente social da universidade. Como possível consequência disso, a principal iniciativa decorrente da Agenda Ambiental, a coleta seletiva no campus, acabou apresentando resultados parciais e insatisfatórios. 
Ainda segundo o orientador deste trabalho, em 2016, foi reunido novo grupo professores, que passaram a discutir uma nova Agenda, agora denominada de Agenda Socioambiental. Foram formados grupos de trabalho por tema e depois, durante a Semana de Meio Ambiente de 2016, alunos e funcionários foram estimulados a participar de várias reuniões, nas quais foram elaboradas novas metas, projetos prioritários e indicadores métricos. Os grupos continuaram os trabalhos e os resultados de cada grupo temático estão sendo atualmente consolidados, com a perspectiva de aprovação da nova Agenda para meados ou final de 2018.

Com relação à parte educacional, em 2016, a entrevistada conduziu um estudo interno para mapeamento de disciplinas que abordavam a questão socioambiental nos diferentes cursos de graduação. $O$ estudo apontou que eram oferecidas 47 disciplinas obrigatórias e/ou eletivas, além de 3 disciplinas optativas em pelo menos 20 dos 33 cursos oferecidos na universidade. Segundo a entrevistada, embora esse número seja animador em um primeiro olhar, a quantidade de disciplinas vem diminuindo, já que hoje há uma ênfase para assuntos tecnológicos, humanos e psicológicos em detrimento ao ambiental. No entanto, alunos costumam pedir mais disciplinas sobre aspectos da sustentabilidade. Além disso, a entrevistada apontou a necessidade da interdisciplinaridade e da educação de aspectos de civilidade e ética, bases para a educação ambiental consciente. Assuntos como política, interdependência, debates sobre visão de mundo e educação para a humanidade também compõem temas a serem inseridos no contexto para a educação ambiental.

Outro assunto abordado foi relativo as ações executadas pela Universidade no Campus. Com relação à água, são adotadas medidas protetoras no banheiro, como controle de torneira, campanha para uso consciente das folhas de papel para secar as mãos, além do controle de resíduos, tanto nos banheiros quanto nos laboratórios, com a preocupação de não poluir o entorno. Foi relatada a preocupação da universidade em despoluir o rio que passa no meio do terreno, e do cuidado para manutenção da qualidade da água.

Com relação ao lixo, desde a década de 90, a instituição possui separação de lixo, em coleta seletiva. Na visão da entrevistada, essa separação poderia ser mais eficiente, com melhorias no hábito da separação dos resíduos pelos próprios alunos e docentes, e formas mais eficientes na operação. 
Com relação à energia no campus, a entrevistada sugere a instalação de placas solares como forma de diminuir o consumo da rede elétrica e utilizar uma fonte energética própria, ao invés de apenas consumir da rede pública.

Sobre a relação com a comunidade, a universidade concede bolsas acadêmicas por performance e por questões monetárias, dependendo do desempenho do aluno. De acordo com o orientador deste trabalho, a instituição dispõe de uma Vice-Reitoria para tratamento de assuntos relacionados com a comunidade, com ações social e diversos projetos em andamento.

\section{2.}

\section{Análise e Interpretação dos dados quantitativos}

\subsubsection{1.}

\section{Análise geral dos dados coletados}

O número de respondentes da pesquisa da Instituição $X$ foi de 758 , já com os tratamentos da base aplicados. Dos respondentes, a maioria são mulheres, $60,16 \%$ de mulheres e $39,84 \%$ de homens, tanto alunos quanto docentes $(51,58 \%$ de alunas e $33,11 \%$ de alunos, $8,58 \%$ de docentes do sexo feminino e $6,73 \%$ de docentes do sexo masculino), conforme Figura 10 abaixo.

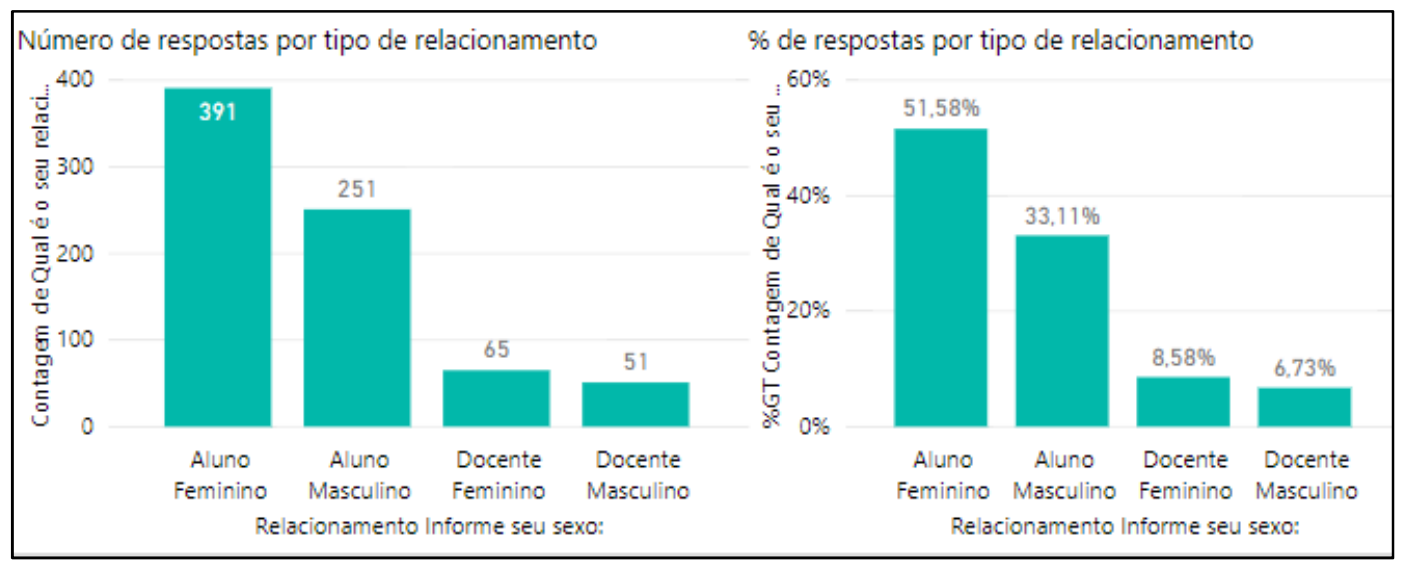

Figura 10: Respostas por sexo - Instituição X Fonte: Elaboração própria

Para melhor entendimento das respostas da primeira parte do questionário, é possível segmentar a base por tipo de relacionamento, e então, classificar os respondentes por idade, curso e resposta para a pergunta do conceito de desenvolvimento sustentável. Dessa forma, há mais clareza sobre o público respondente, dada a diferença entre docentes e alunos. 
Com relação à idade, 125 respostas foram dadas por respondentes com até 19 anos, todos alunos. A maioria dos respondentes têm entre 20 e 29 anos, com 468 respostas de alunos e apenas 1 resposta de docentes. Com relação a faixa de 30 a 39 anos, foram 45 respostas, sendo 32 alunos e 13 docentes. A faixa de 40 a 49 foi a com menos respondentes, com 31 no total (10 alunos e 21 docentes). A faixa de 50 a 59 anos obteve 43 respostas, 6 alunos e 37 docentes. Por fim, a faixa Acima de 60 anos obteve 45 respostas, 1 aluno e 44 docentes. Podemos observar que, com o avançar da faixa etária, a proporção docentes/alunos aumenta, sendo maior que 1 a partir da faixa de 40 a 49 anos. Na Figura 11, é possível observar os dados e como se comporta a distribuição por idade, em relação ao total de respostas da Instituição $X$.

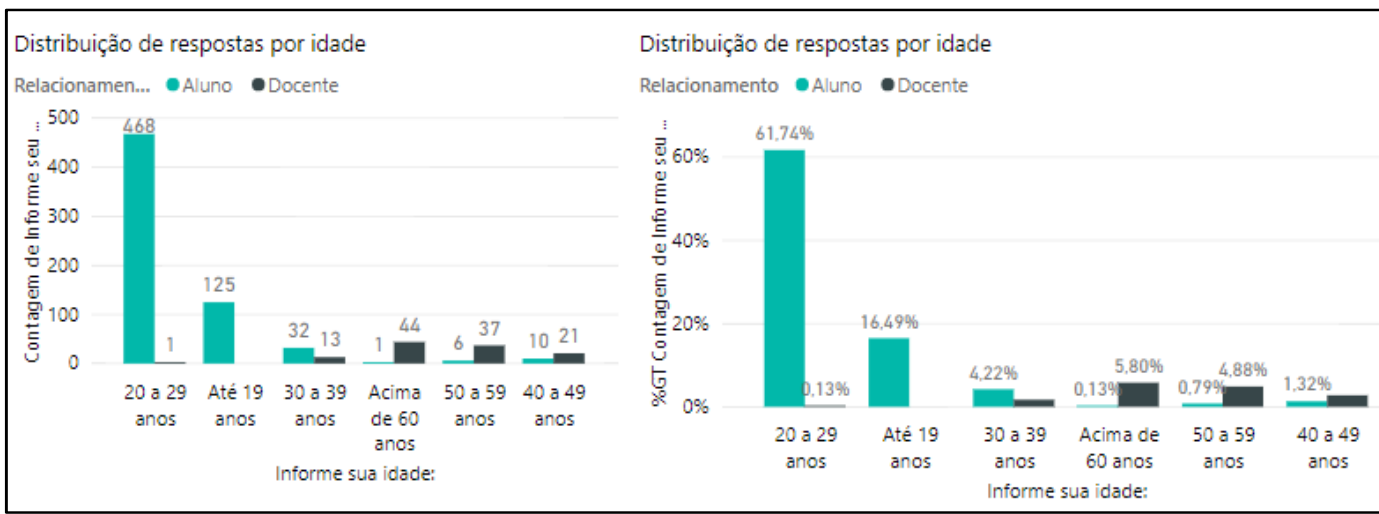

Figura 11: Respostas por idade - Instituição X Fonte: Elaboração própria

Participaram pessoas de 31 diferentes cursos na Instituição X. O curso com maior número de respostas foi o de engenharia, com 213 respostas (195 alunos e 18 docentes), correspondente a $28,1 \%$ dos dados. Em seguida, o curso de Administração de Empresas aparece com 156 respostas (140 alunos e 16 docentes), contribuindo com $20,6 \%$ das respostas. Em terceiro lugar, o curso de Direito contou com 89 respostas (11,7\% do total), com 79 alunos e 10 docentes respondentes. Os resultados são exibidos na Figura 12. 


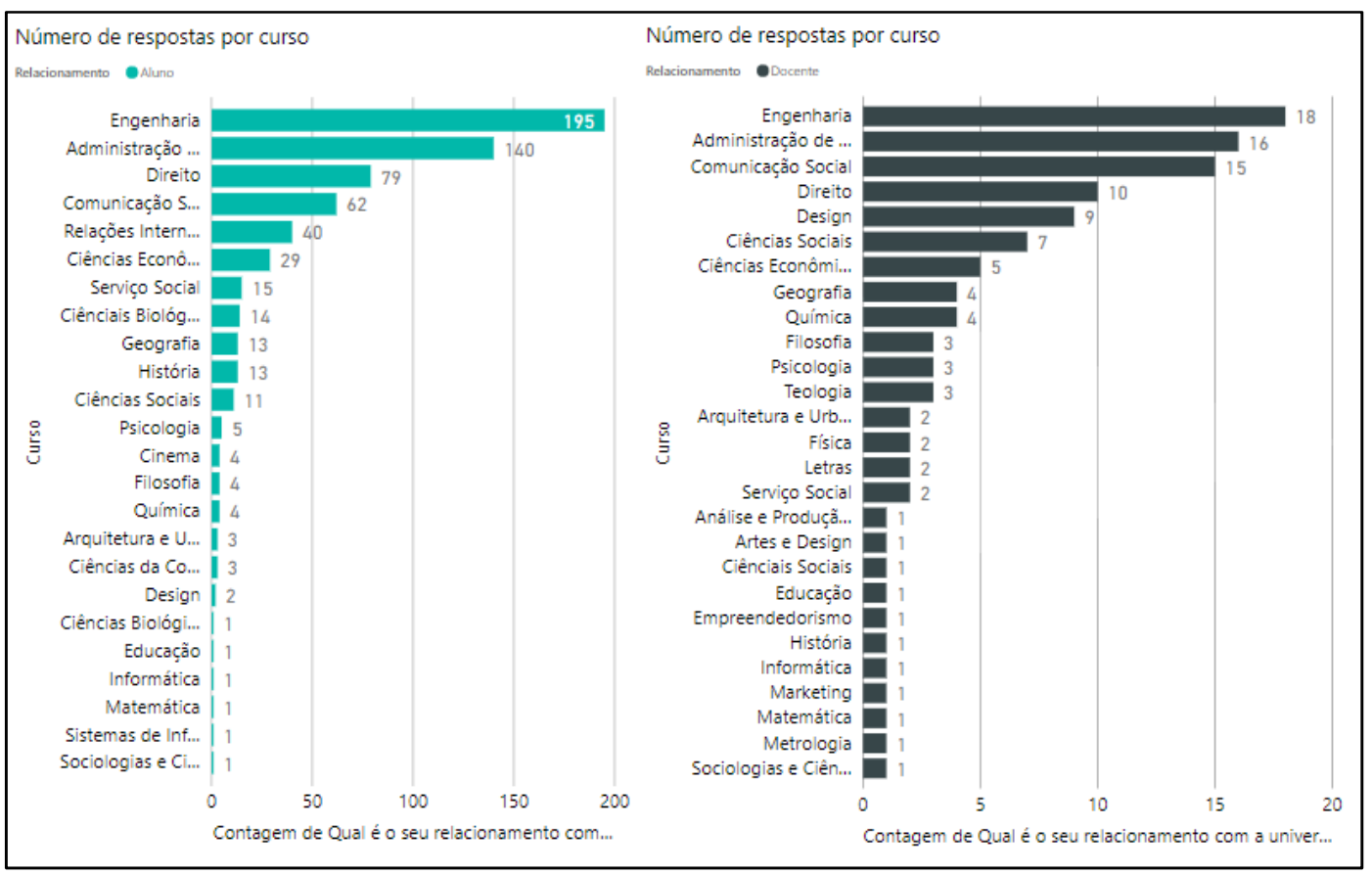

Figura 12: Respostas por curso - Instituição X Fonte: Elaboração própria

A seguir, serão analisadas as variáveis do questionário aplicado, através de estatística descritiva de média e frequência de respostas, segmentados por público, docente ou aluno. O objetivo é verificar qual foi o padrão de respostas por pergunta, e quais análises podem ser feitas em cima dos dados.

\subsubsection{1. \\ Atitudes}

Para a variável Atitude1 "O ensino de princípios de sustentabilidade deve ser integrado ao currículo em todas as disciplinas e em todos os níveis de escolaridade.", obtiveram a maioria de respostas as opções 5 e 4, com 55,5\% e $35,8 \%$ das respostas válidas, respectivamente, indicando maioria de concordância positiva para esta variável (total de $91,3 \%$ das respostas). Alunos e docentes obtiveram quase a mesma nota para esta pergunta.

Para a variável Atitude2 "A educação para a cidadania é um componente importante para o alcance do desenvolvimento sustentável.", a maioria das respostas foi a opção 5 - Concordo Totalmente, com $88,1 \%$ das respostas válidas. A segunda opção de resposta mais escolhida foi a opção 4 - Concordo Parcialmente, com $10,3 \%$ das respostas válidas, indicando maioria de concordância positiva com esta variável (98,4\% de respostas positivas). Neste caso, docentes e alunos obtiveram distribuições de respostas parecidas. 
A variável Atitude3 "Iniciativas que busquem uma distribuição mais igualitária de renda contribuem para a solução dos problemas sociais." obteve maioria positiva, com $81,9 \%$ de respostas positivas (31,5\% - opção 4 e 50,4\% opção 5). A percepção negativa desta variável foi de $13,5 \%$, e neutros foram $4,6 \%$ das respostas. Neste item, $75,0 \%$ dos docentes apresentaram concordância total e 19,8\%, concordância parcial, percentuais bem mais elevados do que as respostas dos alunos ( $5-46,0 \%$ e $4-33,6 \%)$.

Para a variável Atitude4 "A indústria deveria desencorajar o uso de produtos e embalagens descartáveis.", $82,6 \%$ das respostas foram positivas (48,8\% - opção 5 e 33,8\% - opção 4), indicando concordância com esta variável. A distribuição das respostas entre docentes e alunos foi parecida.

Para a variável Atitude5 "Precisamos de leis e normas reguladoras mais rígidas para proteger o meio ambiente.", 90,4\% das respostas foram positivas (67\% - opção 5 e 23,4\% - opção 4), indicando concordância geral com esta variável. Alunos obtiveram maior concordância completa com o tema, com $68,7 \%$ de respostas na opção 5 , enquanto que docentes obtiveram $57,8 \%$ das respostas marcadas nesta opção.

Por fim, a variável Atitude6 "O desenvolvimento sustentável não será possível até que as nações mais ricas parem de explorar os trabalhadores e os recursos naturais dos países mais pobres." também apresentou maioria positiva, com $66,2 \%$ de respostas válidas $(34,2 \%$ de respostas na opção 5 e $34 \%$ de respostas na opção 4), porém menor do que as demais variáveis. $21,2 \%$ dos respondentes têm atitude negativa para esta variável (14,9\% de respostas na opção 2 e 6,3\% de respostas na opção 1), e 10,6\% dos respondentes são neutros. Docentes responderam mais positivamente a este item do que alunos. 


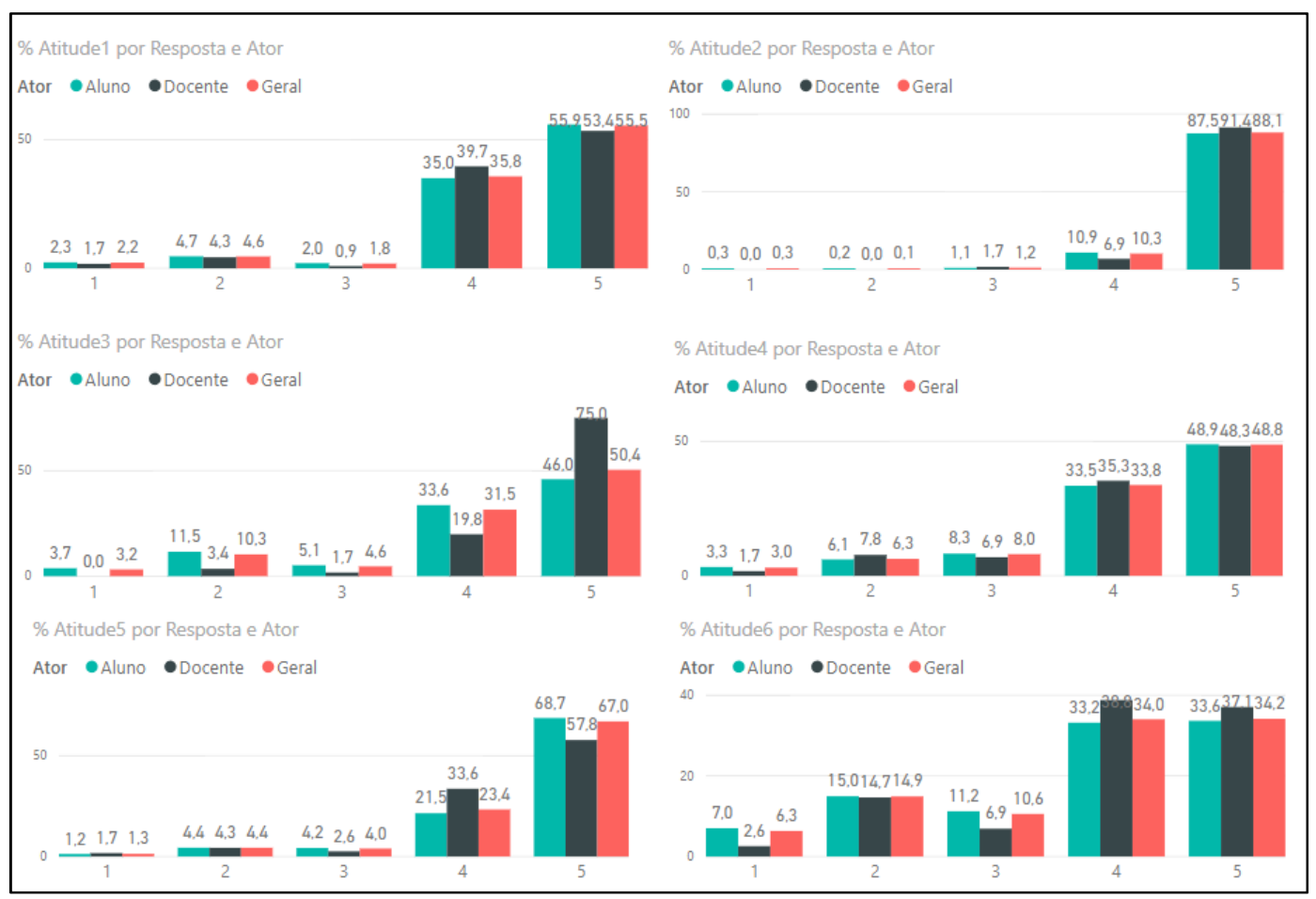

Figura 13: \% das respostas por público - Instituição $X$ - Atitude Fonte: Elaboração própria

De acordo com a Figura 13, é possível observar a predominância das respostas 4 e 5 , atestando a maioria positiva para as variáveis relacionadas a atitude. Com relação as médias das variáveis, todas apresentaram valor positivo (acima de 4), com exceção da variável Atitude6, com 3,75 de média, já que essa variável obteve mais votos negativos e neutros do que as demais variáveis do constructo Atitude.

Observa-se também que que docentes obtiveram média mais alta nos quesitos Atitude1, Atitude2, Atitude3, Atitude4, Atitude6 e Atitude, indicando maior concordância com os temas do desenvolvimento sustentável do que alunos, que obtiveram maior média apenas na variável Atitude5.

A variável Atitude, determinada pela média das variáveis relacionadas à atitude, obteve valor de 4,31, indicando Atitude média positiva dos respondentes da Instituição X, conforme resultados exibidos na Tabela 7.

\begin{tabular}{|c|c|c|c|c|c|c|c|c|}
\hline Relacionamento & $\mathbf{N}$ & Atitude1 & Attiude2 & Atitude3 & Atitude4 & Atitude5 & Atitude6 & Atitude \\
\hline Aluno & 642 & 43,8 & 4,85 & 4,07 & 4,19 & 4,52 & 3,71 & 4,29 \\
\hline Docente & 116 & 43,9 & 4,90 & 4,66 & 4,21 & 4,41 & 3,93 & 4,42 \\
\hline Total & $\mathbf{7 5 8}$ & $\mathbf{4 , 3 8}$ & $\mathbf{4 , 8 6}$ & $\mathbf{4 , 1 6}$ & $\mathbf{4 , 1 9}$ & $\mathbf{4 , 5 0}$ & $\mathbf{3 , 7 5}$ & $\mathbf{4 , 3 1}$ \\
\hline
\end{tabular}

Tabela 7: Médias Atitude - Instituição X

Fonte: Elaboração própria 


\subsubsection{2. \\ Comportamento}

Com relação à variável Comportamento1 "Ajudo a resolver problemas sociais por meio de trabalho social voluntário ou doações a entidades de caridade.", a maioria dos respondentes sinalizaram positivamente, com 29,7\% das respostas na opção 5 e 38,1\% das respostas na opção 4 . Outros 15,6\% dos respondentes escolheram a opção 3 - Nem concordo nem discordo, indicando que este assunto não é observado por 118 respondentes. As distribuições das respostas entre alunos e docentes é parecida, mas alunos obtiveram mais respostas positivas do que docentes.

Para a variável Comportamento2 "No transporte público, cedo meu lugar às pessoas com necessidades especiais (idosos, gestantes, etc.).", a maioria das respostas foi a opção 5 - Concordo Totalmente, com $88,7 \%$ das respostas válidas, e em segundo lugar, a opção 4- Concordo Parcialmente com 9,9\% das respostas, indicando maioria de concordância positiva com esta variável (98,6\%).

A variável Comportamento3 "Faço coleta seletiva em casa separando o lixo reciclável do não reciclável." obteve $58,1 \%$ de respostas positivas $(22,2 \%$ opção 4 e 35,9\% - opção 5). A percepção negativa desta variável foi de 31,6\%, (19,9\% - opção1 e 11,7\% - opção 2) e neutros foram 10,3\% das respostas. Observamos que docentes têm mais este hábito do que alunos, já que 61,2\% dos docentes responderam a opção 5 , enquanto que apenas $31,3 \%$ dos alunos concordaram totalmente. Com relação a discordância total, $22,6 \%$ dos alunos e $5,2 \%$ dos docentes não realizam nenhum tipo de separação.

Para a variável Comportamento4 "Quando vou ao mercado, levo uma sacola retornável para não usar sacolas plásticas.", 50,7\% das respostas foram positivas (23,9\% - opção 5 e 26,8\% -opção 4). Cerca de um quarto dos respondentes sempre lembram de levar sua sacola, enquanto que $38,9 \%$ dos respondentes não têm o hábito (26,9\% respostas na opção 1 e $12 \%$ na opção 2). Docentes têm este hábito mais do que alunos, que apresentaram $29 \%$ das respostas de discordância total, contra $15,5 \%$ das respostas na opção 1 pelos docentes.

Para a variável Comportamento5 "Compro prioritariamente de empresas que pratiquem ações voltadas para a redução da pobreza.", o maior percentual de respostas foi na opção 3, revelando pouca observância do tema pelos respondentes, com $36 \%$ das respostas. Docentes também esta prática mais comum do que alunos, conforme Figura 14. 


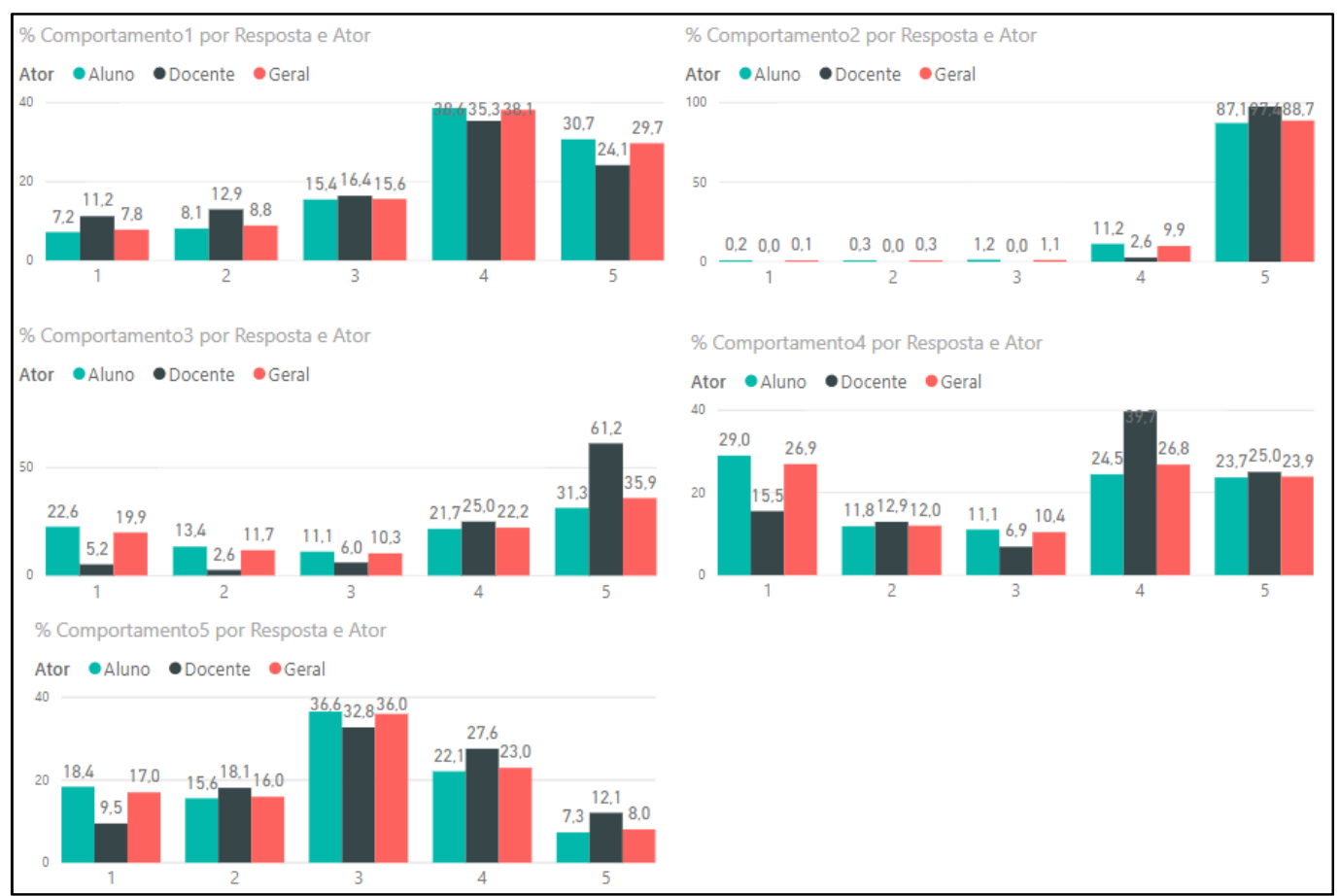

Figura 14: \% das respostas por público - Instituição X - Comportamento Fonte: Elaboração própria

Com relação às médias das variáveis Comportamento, apenas a variável Comportamento2 apresentou valor maior do que 4. A variável Comportamento5 obteve média menor do que 3 , indicando pouca aderência ao comportamento descrito. Observa-se que docentes têm comportamentos mais propositivos para o desenvolvimento sustentável do que alunos, com pontuações superiores para todas as variáveis, a exceção da variável Comportamento1.

O Comportamento medido apresentou valor médio de 3,60, indicando que apesar de existir uma consciência sobre o desenvolvimento sustentável, as ações para o atingimento do mesmo podem ser mais frequentes, principalmente entre alunos, conforme exibido na Tabela 8.

\begin{tabular}{|c|c|c|c|c|c|c|c|}
\hline Relacionamento & $\mathbf{N}$ & Comp1 & Comp2 & Comp3 & Comp4 & Comp5 & Comportamento \\
\hline Aluno & 642 & 3,78 & 4,85 & 3,26 & 3,02 & 2,84 & 3,55 \\
\hline Docente & 116 & 3,48 & 4,97 & 4,34 & 3,46 & 3,15 & 3,88 \\
\hline Total & $\mathbf{7 5 8}$ & $\mathbf{3 , 7 3}$ & $\mathbf{4 , 8 7}$ & $\mathbf{3 , 4 2}$ & $\mathbf{3 , 0 9}$ & $\mathbf{2 , 8 9}$ & $\mathbf{3 , 6 0}$ \\
\hline
\end{tabular}

Tabela 8: Médias Comportamento - Instituição X Fonte: Elaboração própria 


\subsubsection{3. \\ Campus}

A variável Campus1 "A universidade possui ações permanentes de coleta seletiva e tratamento adequado de seus resíduos." indica que a maioria dos respondentes observam iniciativas de tratamento de lixo na universidade, com $77,9 \%$ das respostas positivas $(36,3 \%$ das respostas na opção 4 e $41,6 \%$ das respostas na opção 5). Docentes e alunos apresentaram percepções similares, com percentuais de respostas parecidos em todas as variáveis.

A variável Campus2 "A universidade incentiva práticas de consumo consciente de água e energia." apresentou $42,4 \%$ de respostas positivas (16,1\% das respostas na opção 5 e 26,1\% das respostas na opção 4), com destaque para a percepção dos docentes (54,3\% responderam positivamente). Mais de um quarto dos alunos são indiferentes $(26,6 \%$ das respostas de alunos a esta pergunta, e 33,4\% os respondentes responderam negativamente.

Com relação à variável Campus3 "A universidade tem ações para atender os portadores de necessidades especiais (acessibilidade, no campus, oferta de empregos para portadores de deficiências, idosos, etc.).", 82,3\% percebem positivamente (42,9\% respostas na opção 5 e 39,4\% na opção 4). Os dados apontam que, percentualmente, mais alunos são indiferentes a esta questão do que docentes.

A variável Campus4 "A universidade promove um ambiente propício à diversidade (religiosa, étnica, cultural, ideológica, de gênero, etc.)." apresentou resultados de percepção positiva, com 53,2\% das respostas na opção 5 e 32,1\% na opção 4. Docentes têm a percepção mais elevada do que alunos neste quesito, (93,1\% de percepções positivas de docentes e $83,8 \%$ alunos).

Com relação à variável Campus5 "A universidade realiza investimentos de forma sistemática para tornar o Campus mais sustentável", 31,9\% dos respondentes não têm uma percepção definida, 55,1\% observam positivamente e $13 \%$, negativamente. Docentes observam mais positivamente o quesito avaliado, com $66,4 \%$ de percepções positivas, contra $53 \%$ das respostas positivas de alunos, conforme Figura 15. 


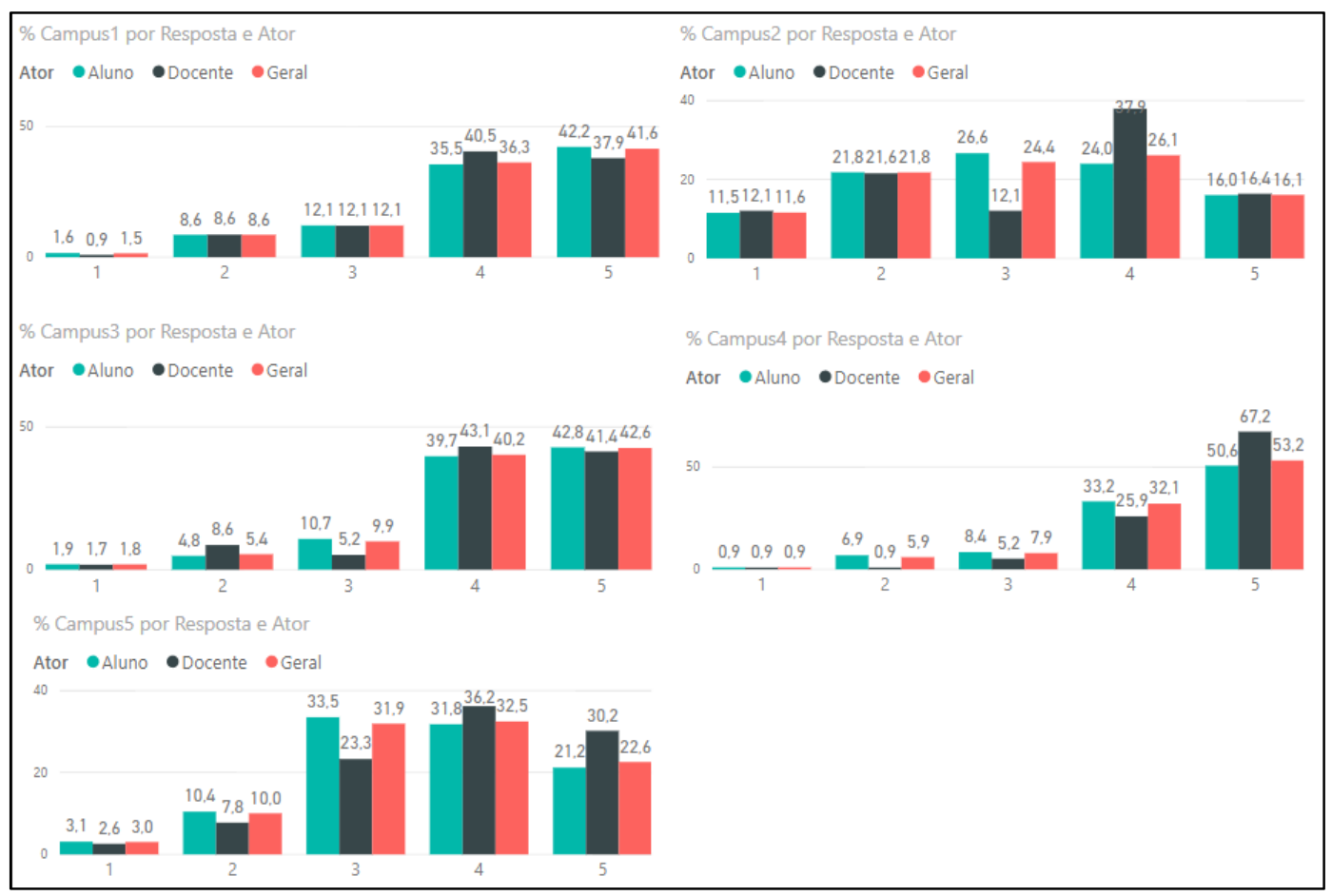

Figura 15: \% das respostas por público - Instituição X - Campus Fonte: Elaboração própria

Com relação à média, as variáveis Campus1, Campus3 e Campus4 são percebidas positivamente por docentes e alunos, enquanto que as variáveis Campus2, Campus5 e Campus6 apresentam valores médios menores que 4,0, conforme Tabela 9. O item pior avaliado se refere a conscientização sobre uso de água e energia, principalmente para alunos. Na média geral, a percepção sobre as ações desenvolvidas pelo Campus apresenta valor de 3,86, valor mediano, o que indica que a Instituição $X$, apesar de realizar ações no campus, ainda pode melhorar nos quesitos avaliados.

\begin{tabular}{|c|c|c|c|c|c|c|c|}
\hline Relacionamento & $\mathbf{N}$ & Campus1 & Campus2 & Campus3 & Campus4 & Campus5 & Campus \\
\hline Aluno & 642 & 4,08 & 3,11 & 4,17 & 4,26 & 3,57 & 3,84 \\
\hline Docente & 116 & 4,06 & 3,25 & 4,14 & 4,58 & 3,84 & 3,97 \\
\hline Total & $\mathbf{7 5 8}$ & $\mathbf{4 , 0 8}$ & $\mathbf{3 , 1 3}$ & $\mathbf{4 , 1 6}$ & $\mathbf{4 , 3 1}$ & $\mathbf{3 , 6 1}$ & $\mathbf{3 , 8 6}$ \\
\hline
\end{tabular}

Tabela 9: Médias Campus - Instituição X

Fonte: Elaboração própria

\subsubsection{4.}

\section{Comunidade}

A variável Comunidade1 "A universidade participa de atividades que promovem o desenvolvimento social da comunidade em que está inserida." obteve maioria das percepções positivas, com 38,4\% das respostas na opção 5 e 36,1\% na opção 4, indicando percepção positiva deste quesito. Quase metade 
dos docentes escolheram a opção 5 para esta questão $(47,4 \%$ das respostas dos docentes), indicando maior observância positiva (concordando totalmente), do que alunos (36,8\%), conforme figura 16.

Com relação à variável Comunidade2 "A universidade participa de atividades voltadas para a solução de questões ambientais da comunidade em que está inserida.", 30,1\% dos respondentes não percebem a atuação da universidade neste item. $57,9 \%$ das respostas foram positivas e $10,4 \%$, negativas. Docentes e alunos têm percepção parecida, com ligeira maior observância positiva pelos docentes (62,1\% docentes e $59,1 \%$ alunos).

A variável Comunidade3 "A universidade promove ou incentiva a participação de seus professores, alunos e funcionários em projetos sociais ou ambientais junto à comunidade em que está inserida." obteve maioria positiva das respostas $(57,1 \%$ das respostas, sendo $21 \%$ na opção 5 e $36,1 \%$ na opção 4). Cerca de um quarto dos respondentes não percebem esta dimensão na universidade $(23,5 \%$ do total), e $19,4 \%$ dos respondentes percebem negativamente esta variável.

Para a variável Comunidade4 "A universidade é aberta a sugestões e críticas de professores, alunos, funcionários e membros da comunidade em que está inserida.", os resultados apontam uma percepção positiva na maioria das respostas (30,7\% na opção 5 e 33,6\% na opção 4). 20,8\% dos respondentes não percebem este item, e $14,8 \%$ dos respondentes percebem negativamente.

A variável Comunidade5 "A universidade realiza ações para promover o desenvolvimento econômico da comunidade em que está inserida." foi a que mais recebeu respostas na opção 3, representando $32,3 \%$ das respostas, indicando a não percepção de cerca de um terço dos respondentes sobre o tema. As respostas positivas somam $51,7 \%$ dos respondentes, e as percepções negativas, 15,9\%. Entre os que percebem, os docentes apresentam percepção mais positiva do que alunos, com maior percentual de respostas nas opções 4 e 5. 


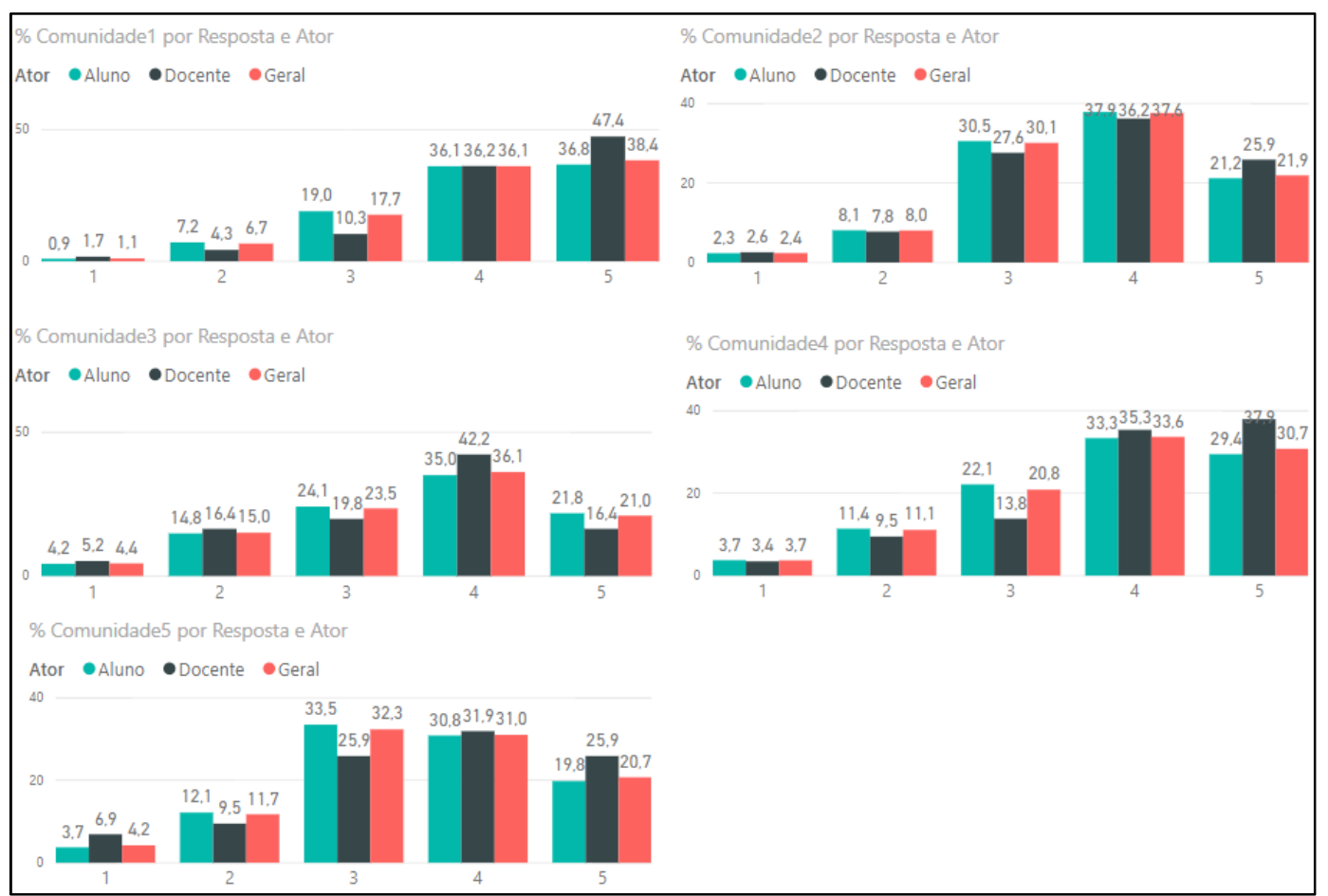

Figura 16: \% das respostas por público - Instituição X - Comunidade Fonte: Elaboração própria

A variável Comunidade não apresentou resultado positivo, com uma média de 3,71 , sendo classificada como percepção média em relação às ações comunitárias para o desenvolvimento sustentável. Apenas a variável Comunidade1 apresentou média maior que 4, com valor 4,04. O resultado observado é influenciado pelo percentual de respostas 3, opção de resposta que indica não observância do item. A variável com menor pontuação foi a Comunidade5, que aborda o apoio da universidade ao desenvolvimento econômico local da comunidade em que está inserida, conforme tabela 10.

\begin{tabular}{|c|c|c|c|c|c|c|c|}
\hline Relacion. & N & Comuni1 & Comuni2 & Comuni3 & Comuni4 & Comuni5 & Comunidade \\
\hline Aluno & 642 & 4,01 & 3,67 & 3,55 & 3,73 & 3,51 & 3,70 \\
\hline Docente & 116 & 4,23 & 3,75 & 3,48 & 3,95 & 3,60 & 3,80 \\
\hline Total & $\mathbf{7 5 8}$ & $\mathbf{4 , 0 4}$ & $\mathbf{3 , 6 9}$ & $\mathbf{3 , 5 4}$ & $\mathbf{3 , 7 7}$ & $\mathbf{3 , 5 2}$ & $\mathbf{3 , 7 1}$ \\
\hline
\end{tabular}

Tabela 10: Médias Comunidade - Instituição X

Fonte: Elaboração própria

\subsubsection{5.}

\section{Educação}

A variável Educação1 "A universidade oferece em seu currículo disciplinas que integram diferentes áreas do conhecimento." foi avaliada positivamente pela maioria dos respondentes, com $84,1 \%$ das respostas positivas. Alunos e docentes percebem este aspecto da educação de maneira semelhante, com 
docentes percebendo mais positivamente do que alunos $(93,4 \%$ de respostas positivas dos docentes e $87,6 \%$ de respostas positivas de alunos).

A variável Educação2 "A universidade promove e incentiva a reflexão sobre o seu papel e forma de atuação na sociedade." foi avaliada de forma positiva pela maioria dos respondentes (38,5\% de respostas na opção 5 e 35,6\% na opção 4), com docentes com maior percepção positiva do que alunos. Percentualmente, mais alunos percebem negativamente este quesito do que docentes, com 7,7\% das respostas de docentes e 10,9\% de alunos nas opções 4 e 5 .

Com relação à variável Educação3 "A universidade incentiva 0 pensamento crítico voltado para o alcance da sustentabilidade.", observa-se uma diferença na percepção de alunos e docentes, já que $16,6 \%$ dos alunos a percebem negativamente, valor bem superior quando comparado ao dos docentes, com apenas $6,1 \%$ das respostas negativas. Considerando a população geral, $68 \%$ percebem positivamente essa variável.

A variável Educação4 "A universidade oferece em seu currículo uma quantidade adequada de disciplinas que abordem 0 desenvolvimento sustentável." foi a que obteve a segunda menor média dentre todas as variáveis analisadas nesta pesquisa, e indica que a percepção da quantidade de disciplinas para o desenvolvimento sustentável é negativa. $44,3 \%$ dos respondentes optaram pelas opções 1 e 2, enquanto que $39,8 \%$ avaliaram a percepção positivamente. Cerca de um quarto dos docentes não percebe essa dimensão, com número percentual quase o dobro em comparação com os alunos (25\% para docentes e $14,3 \%$ para alunos).

A variável Educação5 "A universidade oferece em seu currículo atividades que permitam a prática dos conceitos do desenvolvimento sustentável." apresentou a menor dentre todas as variáveis avaliadas. Os alunos percebem mais negativamente este item do que docentes com $42,5 \%$ de respostas negativas de alunos e $31 \%$ de docentes. Os docentes apresentam, percentualmente, 6,7 pontos acima dos alunos de respostas na opção 3, indicando a falta de percepção de mais de um quarto dos docentes perante o tema (25,9\% de respostas na opção 3 para docentes e 19,2\% para alunos).

Por fim, a variável Educação6 "A universidade incentiva a pesquisa sobre os temas que compõem o conceito de desenvolvimento sustentável." apresentou elevado percentual de respostas $3(28,1 \%$, sendo $29 \%$ de alunos e $23,3 \%$ de docentes), indicando desconhecimento de mais de um quarto dos respondentes 
sobre essa percepção. As percepções positivas foram $57,4 \%$ das respostas totais, e as negativas, 14,5\%, conforme Figura 17.

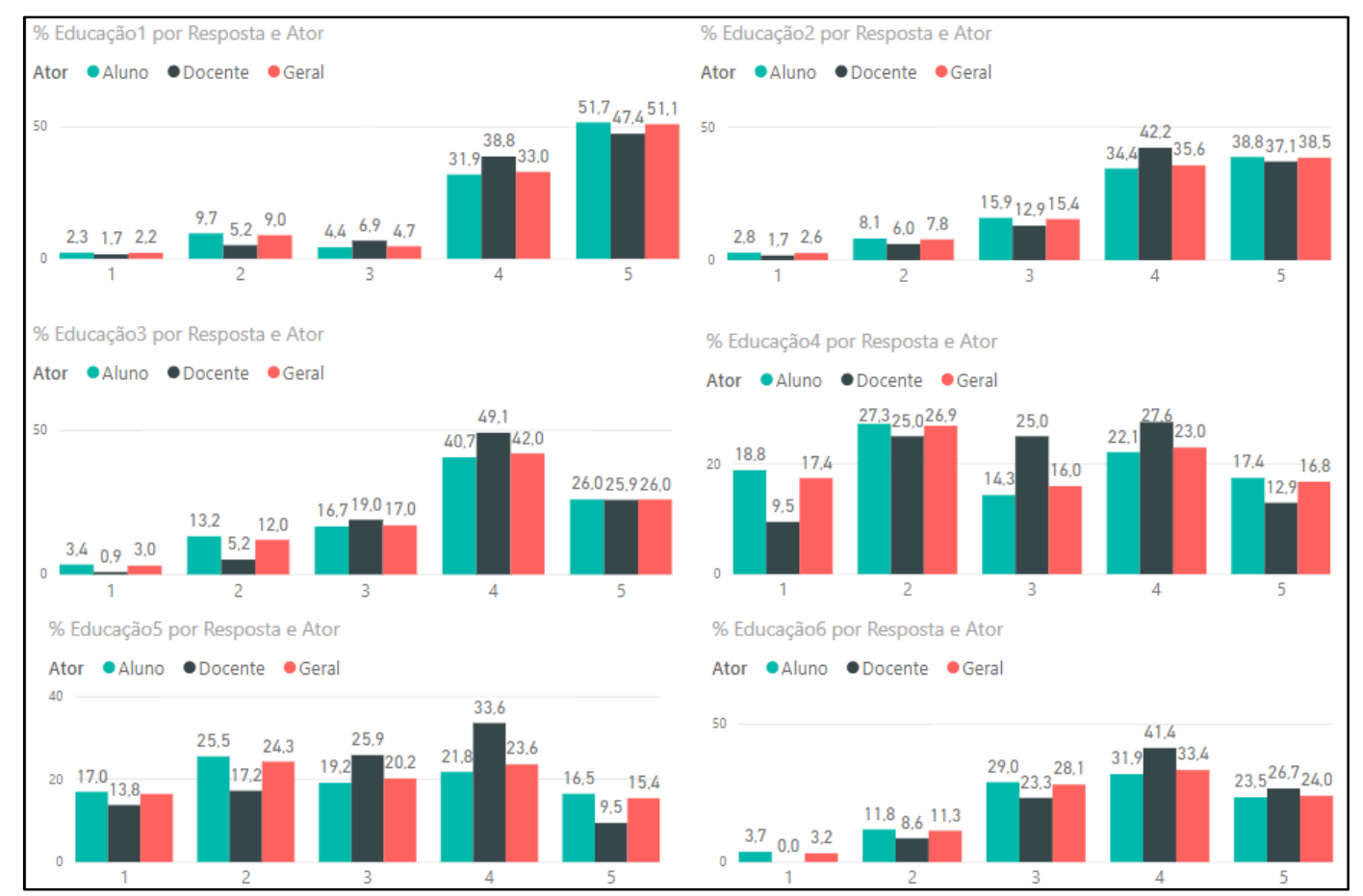

Figura 17: \% das respostas por público - Instituição X - Educação

Fonte: Elaboração própria

Conforme a tabela 11, o valor calculado da variável Educação foi de 3,59, indicando percepção média acerca dos quesitos avaliados nessa dimensão. Para os alunos, as variáveis Educação4 e Educação5 obtiveram percepções negativas, indicando que o número de disciplinas para o desenvolvimento sustentável e o número de disciplinas práticas são insuficientes.

As variáveis Educação4 e Educação5 foram percebidas como negativas na média geral, com valor de 2,95 e 2,97, respectivamente. Em todas as variáveis dessa dimensão, os docentes apresentaram notas mais altas do que alunos, com média final superior em 0,16 pontos na variável Educação.

\begin{tabular}{|c|c|c|c|c|c|c|c|c|}
\hline Relacion. & $\mathbf{N}$ & $\begin{array}{c}\text { Educação } \\
\mathbf{1}\end{array}$ & $\begin{array}{c}\text { Educação } \\
\mathbf{2}\end{array}$ & $\begin{array}{c}\text { Educação } \\
\mathbf{3}\end{array}$ & $\begin{array}{c}\text { Educação } \\
\mathbf{4}\end{array}$ & $\begin{array}{c}\text { Educação } \\
\mathbf{5}\end{array}$ & $\begin{array}{c}\text { Educação } \\
\mathbf{6}\end{array}$ & Educação \\
\hline Aluno & 642 & 4,21 & 3,98 & 3,73 & 2,92 & 2,95 & 3,60 & 3,56 \\
\hline Docente & 116 & 4,25 & 4,07 & 3,94 & 3,09 & 3,08 & 3,86 & 3,72 \\
\hline Total & $\mathbf{7 5 8}$ & $\mathbf{4 , 2 2}$ & $\mathbf{4 , 0 0}$ & $\mathbf{3 , 7 6}$ & $\mathbf{2 , 9 5}$ & $\mathbf{2 , 9 7}$ & $\mathbf{3 , 6 4}$ & $\mathbf{3 , 5 9}$ \\
\hline
\end{tabular}

Tabela 11: Médias Educação - Instituição X

Fonte: Elaboração própria 


\subsubsection{6. Promoção}

A variável Promoção1 "A universidade divulga frequentemente material sobre questões relacionadas ao desenvolvimento sustentável (econômico, social e ambiental)." foi avaliada com alto valor de indiferença, com 27,7\% das respostas na opção 3. A percepção positiva foi observada por $36,7 \%$ das respostas (16,8\% das respostas na opção 5 e 29,9\% na opção 4), enquanto que foram $25,6 \%$ os respondentes com percepção negativa.

A variável Promoção2 "O conteúdo dos materiais divulgados pela universidade contribui para uma maior conscientização sobre o desenvolvimento sustentável." obteve ainda maior percentual de respostas na opção 3, com $31,8 \%$ do total. As respostas positivas foram $49 \%$ do total (17,9\% na opção 5 e $31,1 \%$ na opção 4), e as negativas, 18,9\%, conforme Figura 18.

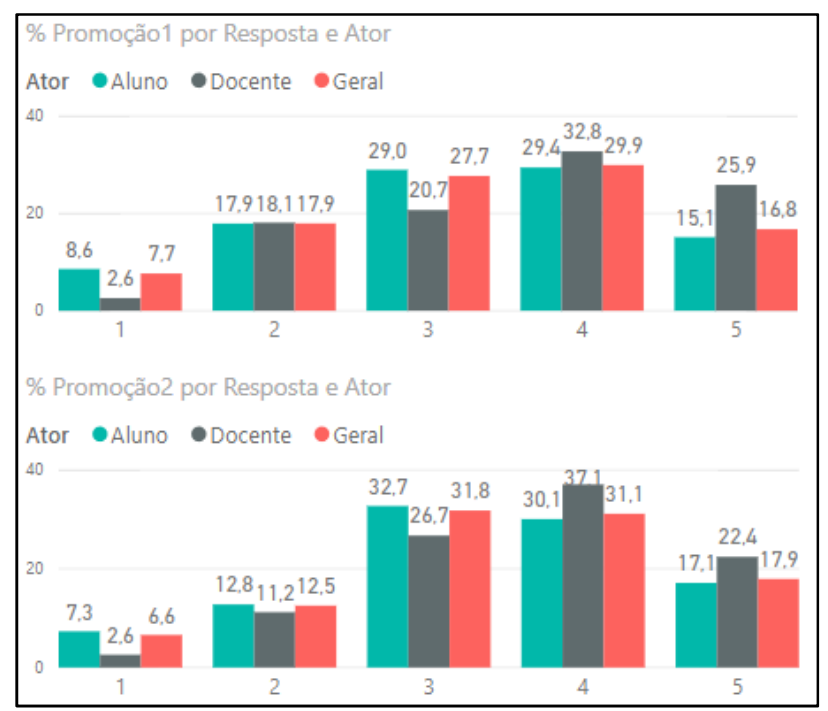

Figura 18: \% das respostas por público - Instituição X - Promoção Fonte: Elaboração própria

O valor médio da variável Promoção foi de 3,36, indicando percepção média para o público respondente. O alto índice de respostas na opção 3 demonstra que muitos não têm a percepção do tema. Quanto aos demais respondentes, a maioria respondeu positivamente ao questionário, indicando a observância positiva acerca dos temas avaliados. Os docentes percebem mais positivamente este item do que alunos, já que suas médias foram superiores às dos alunos, conforme tabela 12 . 


\begin{tabular}{|c|c|c|c|c|}
\hline Relacionamento & $\mathbf{N}$ & Promoção1 & Promoção2 & Promoção \\
\hline Aluno & 642 & 3,25 & 3,37 & 3,31 \\
\hline Docente & 116 & 3,61 & 3,66 & 3,63 \\
\hline Total & $\mathbf{7 5 8}$ & $\mathbf{3 , 3 0}$ & $\mathbf{3 , 4 1}$ & $\mathbf{3 , 3 6}$ \\
\hline
\end{tabular}

Tabela 12: Médias Promoção - Instituição X

Fonte: Elaboração própria

\subsubsection{7.}

\section{Satisfação}

Esta dimensão avaliou a satisfação de alunos e docentes sobre as ações da universidade nas dimensões Campus, Comunidade e Educação. As opções de resposta dessa seção correspondem a uma escala numérica de 1 a 5, onde Totalmente Insatisfeito corresponde ao valor 1, Parcialmente Insatisfeito - 2, Nem insatisfeito nem satisfeito - 3, Parcialmente Satisfeito - 4 e Totalmente Satisfeito -5 .

A variável Satisfação1 "Como você avalia sua satisfação com as ações para o desenvolvimento sustentável que a Universidade realiza no Campus?" obteve percentual baixo de respostas 5, apenas 10,4\%. A opção 4 recebeu $45,4 \%$ das respostas, indicando maioria das percepções, em que mais da metade dos docentes responderam essa opção, com 51,7\%. O índice de respostas na opção 1 foi de apenas 2,1\% da amostra, e 21,8\% são indiferentes a este quesito. A variável Satisfação2 "Como você avalia sua satisfação com o relacionamento que a Universidade desenvolve com a comunidade?" apresentou um alto número de respostas indiferentes, com $29,4 \%$ das escolhas. O total de respostas positivas corresponde a $47,2 \%$ e $23,3 \%$ são as respostas de percepções negativas. Com relação à variável Satisfação3, que avalia a satisfação com a educação para o desenvolvimento sustentável, apenas 4,3\% dos docentes escolheram a opção 5, enquanto que $10,4 \%$ do geral optaram por essa opção. $50 \%$ das respostas de docentes $40 \%$ das respostas dos alunos foram a opção 4, indicando maioria positiva das percepções. 19,8\% dos respondentes são indiferentes a essa questão, e 23,9\% avaliam negativamente. 


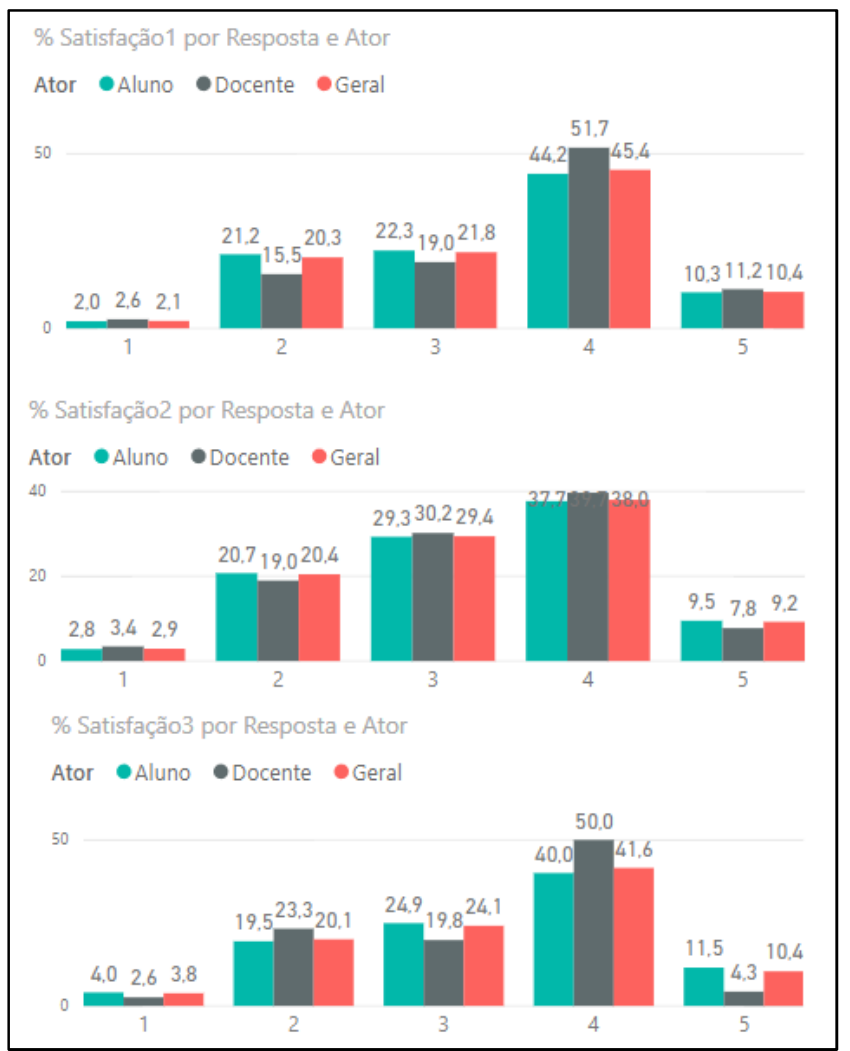

Figura 19: \% das respostas por público - Instituição X - Satisfação Fonte: Elaboração própria

Conforme tabela 13, a satisfação apresenta nota média de 3,36 no total, que pode ser explicada pelo alto percentual de respostas na opção 3 e por mais de $20 \%$ de respostas negativas. O resultado também era esperado já que todos os resultados de percepção foram medianos, sugerindo também uma satisfação mediana por parte dos atores. A menor nota obtida foi a da satisfação das ações com a comunidade $(3,30)$. A maior nota, 3,42 , foi para as ações no Campus, e a satisfação com a Educação, ficou com o valor de 3,35.

\begin{tabular}{|c|c|c|c|c|c|}
\hline Relacionamento. & $\mathbf{N}$ & Satisfação1 & Satisfação2 & Satisfação3 & Satisfação \\
\hline Aluno & 642 & 3,40 & 3,30 & 3,36 & 3,35 \\
\hline Docente & 116 & 3,53 & 3,29 & 3,30 & 3,38 \\
\hline Total & $\mathbf{7 5 8}$ & $\mathbf{3 , 4 2}$ & $\mathbf{3 , 3 0}$ & $\mathbf{3 , 3 5}$ & $\mathbf{3 , 3 6}$ \\
\hline
\end{tabular}

Tabela 13: Médias Satisfação - Instituição X

Fonte: Elaboração própria

\subsubsection{8.}

\section{Participação}

A participação de alunos e docentes foi medida em relação ao passado e presente e ao futuro. Percebemos que a grande maioria dos atores $(82,2 \%)$ não se engajam em atividades para o desenvolvimento sustentável, e apenas 17,8\% responderam positivamente para a variável Participação1. Docentes se engajam 
mais que alunos, com $21,3 \%$ das respostas positivas, enquanto que apenas $15,8 \%$ dos alunos informaram que o fizeram, conforme figura 20.

Sobre a possibilidade de participação em ações no futuro, medida pela variável Participação3, 47,1\% dos respondentes optaram pela opção 5, indicando total concordância com a participação. 35,5\% escolheram a opção 4, totalizando $82,6 \%$ de respostas positivas para este quesito. $12,4 \%$ se mantiveram indiferentes, e apenas $5 \%$ responderam negativamente. 50,1\% dos alunos e $29,5 \%$ dos docentes responderam com a opção 5, enquanto que 31,2 $\%$ dos alunos e $54,1 \%$ dos docentes escolheram a opção 4.

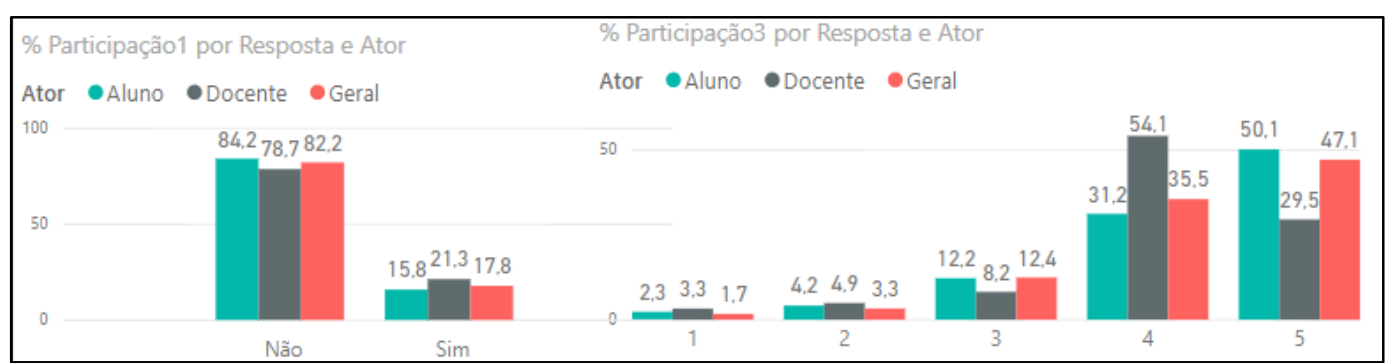

Figura 20: Respostas por público - Instituição X - Participação

Fonte: Elaboração própria

Como a maioria das respostas foram nas opções 4 e 5 , a média da variável Participação3 foi alta, com o valor de 4,23 como média final, com alunos com maior nota do que docentes, conforma Tabela 14.

\begin{tabular}{|c|c|c|}
\hline Relacionamento & N & Participação1 \\
\hline Aluno & 541 & Não \\
\hline Aluno & 101 & Sim \\
\hline Docente & 82 & Não \\
\hline Docente & 34 & Sim \\
\hline Total & \multicolumn{2}{|c|}{$\mathbf{7 5 8}$} \\
\hline
\end{tabular}

\begin{tabular}{|c|c|c|}
\hline Relacionamento & $\mathbf{N}$ & Participação3 \\
\hline Aluno & 642 & 4,24 \\
\hline Docente & 116 & 4,17 \\
\hline Total & $\mathbf{7 5 8}$ & $\mathbf{4 , 2 3}$ \\
\hline
\end{tabular}

Tabela 14: Respondentes e Média - dimensão Participação Fonte: Elaboração própria

Com relação aos resultados da variável Participação2, que solicita um exemplo de uma ação em que o respondente tenha participado, 23 respondentes informaram que participaram da Semana de Meio Ambiente. As demais respostas estão relacionadas a coleta seletiva, horta no campus, participação em seminários ou palestras dedicadas ao tema, divulgação da Agenda Ambiental e participação em projetos do Núcleo Interdisciplinar de Meio Ambiente. 


\subsubsection{9. \\ Percepção}

A variável criada Percepção é composta pela média das variáveis Educação, Campus e Comunidade, e neste estudo, representa a percepção final de docentes e alunos sobre as ações para o desenvolvimento sustentável da universidade. O resultado, considerando a média de todas as respostas, foi de 3,72. Docentes aparentem ter uma percepção mais positiva do que alunos, em todas as dimensões do estudo.

\begin{tabular}{|c|c|c|c|c|c|}
\hline Relacionamento. & $\mathbf{N}$ & Campus & Comunidade & Educação & Percepção \\
\hline Aluno & 642 & 3,84 & 3,70 & 3,56 & 3,70 \\
\hline Docente & 116 & 3,97 & 3,80 & 3,72 & 3,83 \\
\hline Total & $\mathbf{7 5 8}$ & $\mathbf{3 , 8 6}$ & $\mathbf{3 , 7 1}$ & $\mathbf{3 , 5 9}$ & $\mathbf{3 , 7 2}$ \\
\hline
\end{tabular}

Tabela 15: Médias Satisfação - Instituição X

Fonte: Elaboração própria

\subsubsection{2.}

\section{Testes de hipóteses}

\subsubsection{1. Hipótese 1}

A primeira hipótese testada - Indivíduos que percebem positivamente as ações da universidade nas dimensões Campus, Comunidade e Educação estão mais satisfeitos com as ações de sustentabilidade da universidade nas respectivas dimensões do que indivíduos que não percebem tais ações positivamente, foi avaliada segundo os passos propostos na metodologia para testes não-paramétricos.

\section{Campus}

A primeira dimensão testada é o Campus. Foram classificadas 453 respostas como grupo 1, ou seja, apresentam valor da variável Campus maior ou igual a 4. Com relação ao grupo 2, foram encontradas 244 respostas (valor entre 3 e 3,9) e 61 respostas classificadas como Grupo 3 (valor menor do que 3). 
Com o uso dos dados ranqueados, o valor calculado de Rastreamento de Pilai foi de 0,758, com estatística calculada $p$-value 0,00 . Como $p<$ nível de significância $(0,05)$, rejeitamos a hipótese da igualdade das distribuições das quatro variáveis da dimensão pelos três grupos de classificação da percepção do Campus $\left(X^{2}(4)=566,226 ; N=758 ; p<0.001\right)$, conforme Anexo 1.

Aplicando o teste de Kruskal-Wallis, identificamos que todas as variáveis da dimensão Campus apresentam nível de significância $(p<0,001)$ para a estatística qui-quadrada elevada, ou seja, rejeitamos a hipótese nula de que as distribuições das ordens das classificações nos três grupos não são significantemente diferentes, conforme exibido na Figura 21.

\begin{tabular}{||l|r|c|r|r|}
\hline \multicolumn{5}{|c|}{ Estatísticas de teste $^{\text {a,b }}$} \\
\hline Qui-quadrado & Sat_Cam & \multicolumn{1}{|c|}{ CA1 } & \multicolumn{1}{c|}{ CA2 } & \multicolumn{1}{c|}{ CA3 } \\
df & 162,930 & 339,163 & 339,164 & 329,621 \\
Significância Sig. & 2 & 2 & 2 & 2 \\
\hline \\
a. Teste Kruskal Wallis \\
b. Variável de Agrupamento: NCampus \\
\hline
\end{tabular}

Figura 21: Instituição X - Hipótese 1 - Campus Fonte: Elaboração própria

Em seguida, foram realizadas as comparações múltiplas de médias das ordens, onde constatou-se que todos os grupos têm médias diferentes em relação as variáveis da dimensão Campus, conforme consta no Anexo 1.

Os resultados exibidos na Figura 22 mostram a diferença das distribuições por grupo de percepção e pela satisfação das ações no campus. Assim, podemos afirmar que, com 95\% de significância, que os alunos com percepção positiva do campus estão mais satisfeitos com as ações que a universidade desempenha no campus do que alunos que não têm a percepção positiva da dimensão Campus. 


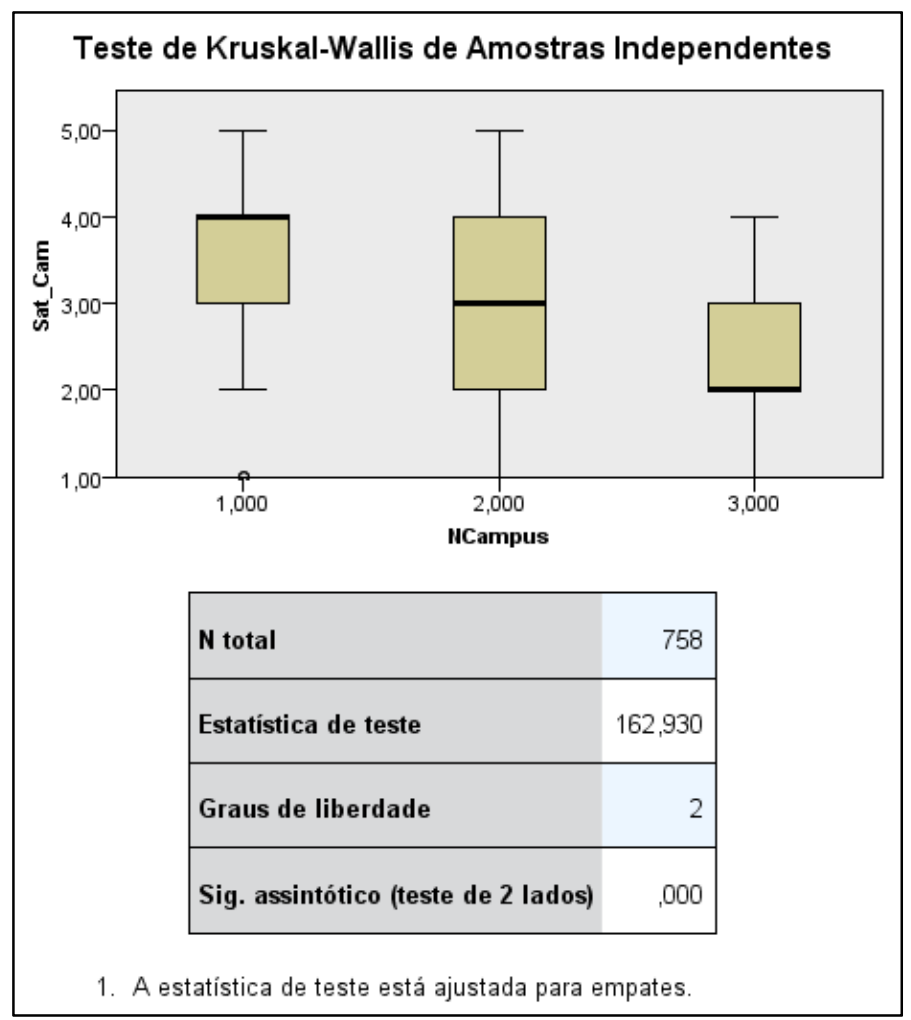

Figura 22: Instituição X - Hipótese 1 - Satisfação Campus Fonte: Elaboração própria

\section{Comunidade}

A dimensão Comunidade obteve 325 respostas do Grupo 1, 313 do Grupo 2 e 120 do Grupo 3. Com o uso dos dados ranqueados, o valor calculado de Rastreamento de Pilai calculado foi de 0,808 , com estatística calculada $p$-value 0,00 . Como $p<$ nível de significância $(0,05)$, rejeitamos a hipótese da igualdade das distribuições das quatro variáveis da dimensão pelos três grupos de classificação da percepção da Comunidade $\left(X^{2}(4)=603,576 ; N=758 ; p<0.001\right)$, conforme Anexo 1.

Aplicando o teste de Kruskal-Wallis, identificamos que todas as variáveis da dimensão Comunidades têm significância $(p<0,001)$, ou seja rejeitamos a hipótese nula de que as distribuições das ordens das classificações nos três grupos não são significantemente diferentes, conforme exibido na Figura 23. Em seguida, foram realizadas as comparações múltiplas de médias das ordens, onde constatou-se que todos os grupos têm médias diferentes em relação as variáveis da dimensão Comunidade, conforme consta no Anexo 1. 


\begin{tabular}{||l|r|r|r|r|}
\hline \multicolumn{5}{|c|}{ Estatísticas de teste $^{\text {a,b }}$} \\
\hline Qui-quadrado & \multicolumn{1}{|c|}{ CM1 } & \multicolumn{1}{|c|}{ CM2 } & \multicolumn{1}{c|}{ CM3 } & Sat_Com \\
df & 393,766 & 397,042 & 395,923 & 215,197 \\
Significância Sig. & 2 & 2 & 2 & 2 \\
\hline \\
a. Teste Kruskal Wallis \\
b. Variável de Agrupamento: NComunidade \\
\hline
\end{tabular}

Figura 23: Instituição X - Hipótese 1 - Comunidade Fonte: Elaboração própria

Os resultados exibidos na Figura 24 mostram a diferença das distribuições por grupo e pela satisfação das ações com a comunidade. Assim, podemos afirmar que, com 95\% de significância, que os alunos com percepção positiva da comunidade estão mais satisfeitos com as ações que a universidade desempenha com a comunidade do que alunos que não têm a percepção positiva da dimensão Comunidade.

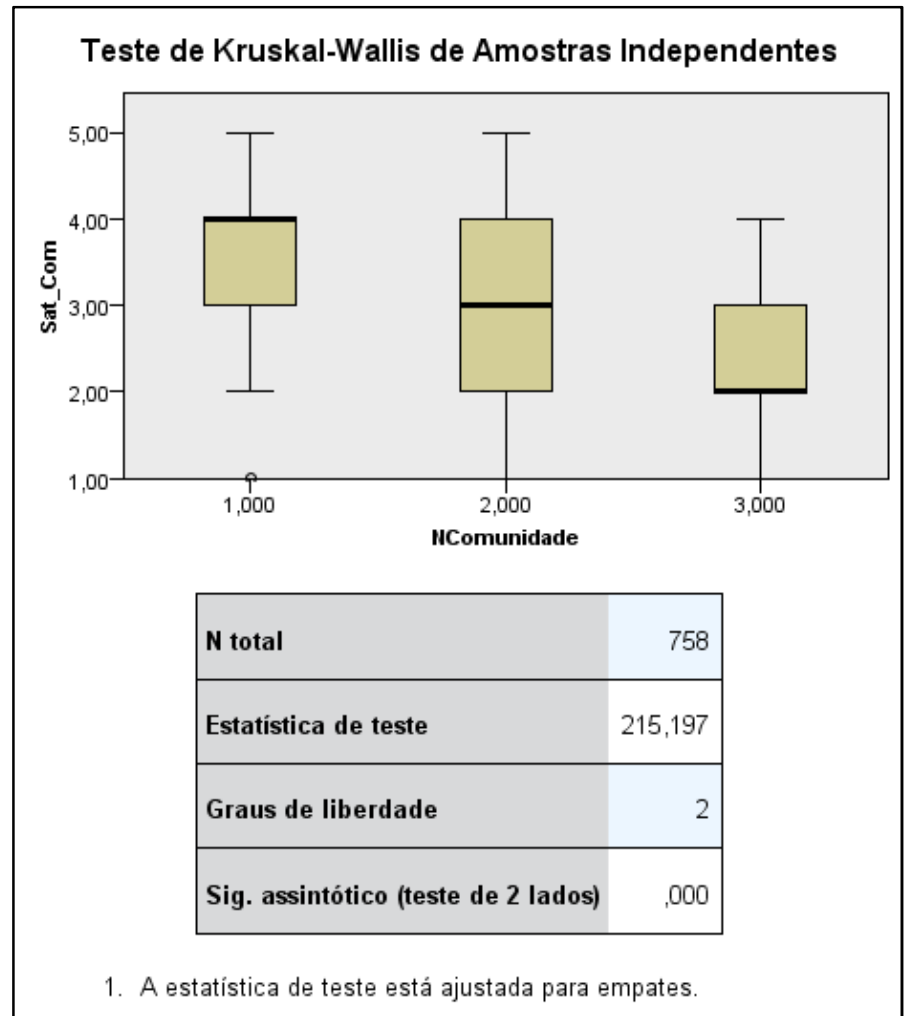

Figura 24: Instituição X - Hipótese 1 - Satisfação Comunidade Fonte: Elaboração própria 


\section{Educação}

A dimensão Educação obteve 308 respostas do Grupo 1, 301 do Grupo 2 e 149 do Grupo 3. Com o uso dos dados ranqueados, o valor calculado de Rastreamento de Pilai calculado foi de 0,871, com estatística calculada $p$-value 0,00 . Como $p<$ nível de significância $(0,05)$, rejeitamos a hipótese da igualdade das distribuições das quatro variáveis da dimensão pelos três grupos de classificação da percepção da Educação $\left(X^{2}(4)=650,637 ; N=758 ; p<0.001\right)$, conforme Anexo 1.

Aplicando o teste de Kruskal-Wallis, identificamos que todas as variáveis da dimensão Educação têm significância $(p<0,001)$, ou seja rejeitamos a hipótese nula de que as distribuições das ordens das classificações nos três grupos não são significantemente diferentes, conforme exibido na Figura 25. Em seguida, foram realizadas as comparações múltiplas de médias das ordens, onde constatou-se que todos os grupos têm médias diferentes em relação as variáveis da dimensão Comunidade, conforme consta no Anexo 1.

\begin{tabular}{|c|c|c|c|c|}
\hline \multicolumn{5}{|c|}{ Estatísticas de teste $^{a, b}$} \\
\hline & ED1 & ED2 & ED3 & Sat_Edu \\
\hline Qui-quadrado & 395,697 & 477,552 & 375,688 & 196,675 \\
\hline df & 2 & 2 & 2 & 2 \\
\hline Significância Sig. &, 000 &, 000 & 000 &, 000 \\
\hline \multicolumn{5}{|c|}{ a. Teste Kruskal Wallis } \\
\hline \multicolumn{5}{|c|}{ b. Variável de Agrupamento: NEducação } \\
\hline
\end{tabular}

Figura 25: Instituição X - Hipótese 1 - Educação

Fonte: Elaboração própria

Os resultados exibidos na Figura 26 mostram a diferença das distribuições por grupo e pela satisfação das ações com a comunidade. Assim, podemos afirmar que, com 95\% de significância, que os alunos com percepção positiva da educação estão mais satisfeitos com as ações que a universidade desempenha no âmbito educacional do que alunos que não têm a percepção positiva da dimensão Educação. 


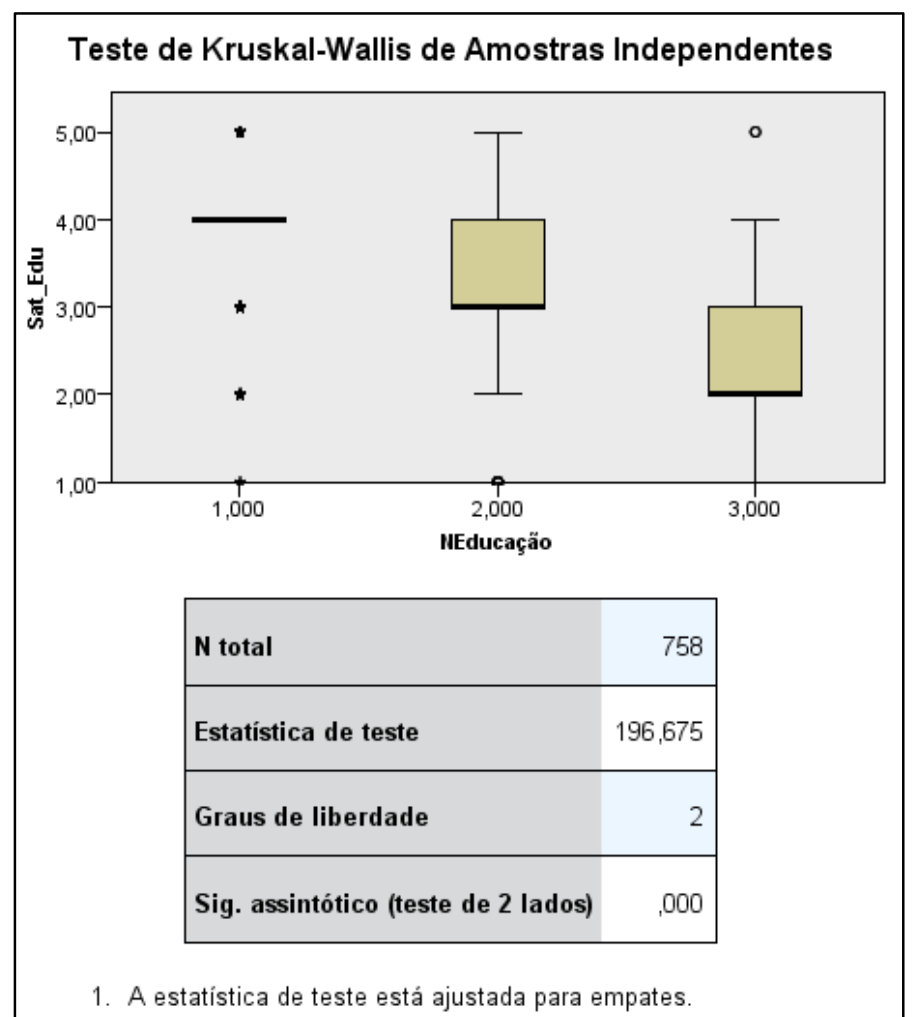

Figura 26: Instituição X - Hipótese 1 - Satisfação Educação Fonte: Elaboração própria

\section{Percepção}

A Percepção obteve 321 respostas do Grupo 1, 346 do Grupo 2 e 91 do Grupo 3. Nesta dimensão, o mesmo teste foi executado duas vezes. A primeira execução englobou todas as variáveis que compõem as dimensões Campus, Comunidade e Educação, sendo testadas 12 variáveis pelo grupamento PercepçãoNível.

O valor de Pilai calculado foi de 0,823 , com estatística calculada $p$-value 0,00 . Como $p<$ nível de significância $(0,05)$, rejeitamos a hipótese da igualdade das distribuições da percepção das variáveis da dimensão pelos três grupos de classificação da percepção $\left(X^{2}(4)=614,781 ; N=758 ; p<0.001\right)$, conforme resultados exibidos no Anexo 1.

Aplicando o teste de Kruskal-Wallis, identificamos que todas as variáveis que compõem a Percepção têm significância ( $p<0,001)$, ou seja, rejeitamos a hipótese nula de que as distribuições das ordens das classificações nos três grupos não são significantemente diferentes. Em seguida, foram realizadas as comparações múltiplas de médias das ordens, onde constatou-se que todos os grupos têm médias diferentes em relação as variáveis analisadas, conforme Figura 27 e Anexo 1. 


\begin{tabular}{|c|c|c|c|c|c|c|c|c|c|c|c|c|}
\hline \multicolumn{13}{|c|}{ Estatísticas de teste $\mathrm{e}^{\mathrm{a}, \mathrm{b}}$} \\
\hline & CA1 & CA2 & CA3 & CM1 & CM2 & CM3 & ED1 & ED2 & ED3 & Sat_Cam & Sat_Com & Sat_Edu \\
\hline Qui-quadrado & 292,870 & 222,874 & 197,422 & 303,869 & 285,017 & 284,594 & 362,299 & 246,081 & 209,674 & 219,632 & 245,417 & 232,549 \\
\hline df & 2 & 2 & 2 & 2 & 2 & 2 & 2 & 2 & 2 & 2 & 2 & 2 \\
\hline Significância Sig. & .000 & .000 & .000 & , 000 & .000 & .000 & .000 & .000 & .000 & .000 & .000 &, 000 \\
\hline
\end{tabular}

Figura 27: Instituição X - Hipótese 1 - Percepção e Satisfação por dimensão

Fonte: Elaboração própria

A primeira rodada de testes identificou que os respondentes que percebem mais positivamente as ações da universidade estão mais satisfeitos com a universidade, por dimensão (Campus, Comunidade e Educação) do que indivíduos que não percebem positivamente.

A segunda execução calculou o valor de Pilai de 0,805 , com estatística $p$ value 0,00 . Como $p<$ nível de significância $(0,05)$, rejeitamos a hipótese da igualdade das distribuições da percepção das variáveis Campus, Comunidade, Educação e Satisfação, nos três grupos de classificação da percepção $\left(X^{2}(4)=\right.$ 601,335; $N=758 ; p<0.001$ ), conforme resultados exibidos no Anexo 1.

Aplicando o teste de Kruskal-Wallis, identificamos que todas as variáveis que compõem a Percepção têm significância ( $p<0,001)$, ou seja, rejeitamos a hipótese nula de que as distribuições das ordens das classificações nos três grupos não são significantemente diferentes. Em seguida, foram realizadas as comparações múltiplas de médias das ordens, onde constatou-se que todos os grupos têm médias diferentes em relação as variáveis analisadas, conforme Anexo 1.

\begin{tabular}{|l|r|r|r|r|}
\hline \multicolumn{5}{|c|}{ Estatísticas de teste $^{\mathrm{a}, \mathrm{b}}$} \\
\hline & Campus & Comunidade & Educação & Satisfação \\
\hline Qui-quadrado & 395,446 & 451,233 & 402,944 & 319,264 \\
df & 2 & 2 & 2 & 2 \\
Significância Sig. &, 000 &, 000 &, 000 &, 000 \\
\hline \multicolumn{4}{|l|}{ a. Teste Kruskal Wallis } \\
b. Variável de Agrupamento: NPercepção \\
\hline
\end{tabular}

Figura 28: Instituição X - Hipótese 1 - Percepção

Fonte: Elaboração própria

Os resultados exibidos na Figura 29 mostram a diferença das distribuições das ordens. Assim, podemos afirmar que, com 95\% de significância, que os alunos com percepção positiva estão mais satisfeitos com as ações que a universidade desempenha para o desenvolvimento sustentável do que alunos com menor percepção das ações da universidade. 


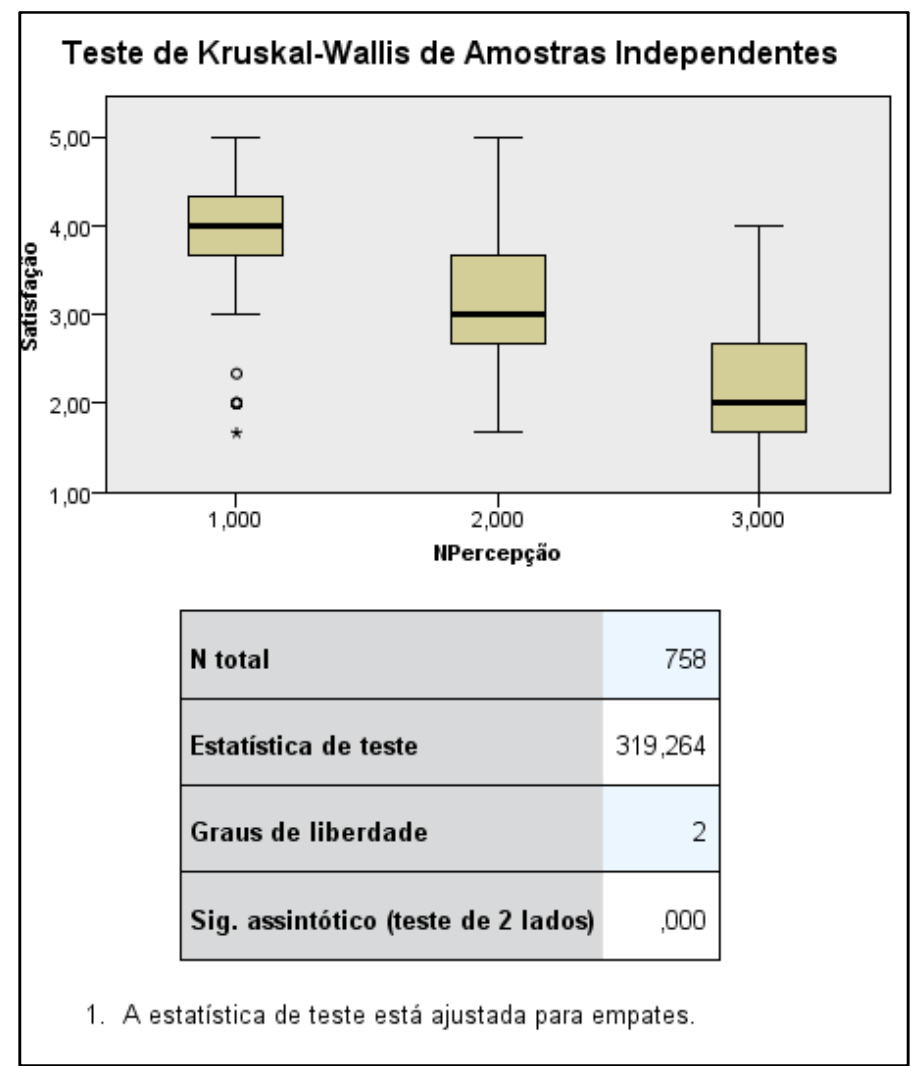

Figura 29: Instituição X - Hipótese 1 - Satisfação Percepção Fonte: Elaboração própria

\subsubsection{2.}

Hipótese 2

A segunda hipótese testada, se indivíduos satisfeitos com as ações de sustentabilidade da universidade são mais propensos a participar de atividades futuras dentro da instituição para o desenvolvimento sustentável do que indivíduos indiferentes ou não satisfeitos, foi avaliada segundo os passos propostos na metodologia para testes não-paramétricos.

A Satisfação obteve 275 respostas do Grupo 1 (satisfação positiva), 288 do Grupo 2 (satisfação média) e 195 do Grupo 3 (satisfação negativa). A execução do teste englobou todas as variáveis que compõem a dimensão Satisfação e a variável Part, sendo testadas as 4 variáveis pelo grupamento SatisfaçãoNível.

O valor do Rastreamento de Pilai calculado foi de 0,907, com estatística calculada $p$-value $<0,001$. Assim, rejeitamos a hipótese da igualdade das distribuições da participação das variáveis da dimensão pelos três grupos de classificação da satisfação $\left(X^{2}(4)=677.529 ; N=758 ; p<0.001\right)$, conforme resultados exibidos no Anexo 1. 
Aplicando o teste de Kruskal-Wallis, identificamos que todas as variáveis que compõem a Satisfação e a variável Part têm significância $(p<0,001)$, ou seja, rejeitamos a hipótese nula de que as distribuições das ordens das classificações nos três grupos não são significantemente diferentes, conforme Figura 30.

\begin{tabular}{|c|c|c|c|c|}
\hline \multicolumn{5}{|c|}{ Estatísticas de teste $\mathrm{e}^{\mathrm{a}, \mathrm{b}}$} \\
\hline & Sat_Cam & Sat_Com & Sat_Edu & Part \\
\hline Qui-quadrado & 475,456 & 510,700 & 448,202 & 23,968 \\
\hline df & 2 & 2 & 2 & 2 \\
\hline Significância Sig. &, 000 &, 000 &, 000 &, 000 \\
\hline \multicolumn{5}{|c|}{ a. Teste Kruskal Wallis } \\
\hline \multicolumn{5}{|c|}{ b. Variável de Agrupamento: NSatisfação } \\
\hline
\end{tabular}

Figura 30: Instituição X - Hipótese 2 - Satisfação por dimensão Fonte: Elaboração própria

A comparação de médias das ordens também ratifica o resultado, apontando que, entre os diferentes grupos de satisfação, os indivíduos apresentam diferenças na propensão à participação em relação ao nível de satisfação com as ações que a universidade desempenha para o desenvolvimento sustentável, conforme exibido no Anexo 1.

No entanto, apesar do resultado apontar a diferença entre as médias dentro dos grupos, uma análise qualitativa permite observar que indivíduos mais satisfeitos não são mais propensos a participar, já que respondentes não satisfeitos (Grupo3), apresentaram valor médio maior do que os respondentes do Grupo1 (indivíduos satisfeitos), conforme Anexo 1. Os indivíduos com satisfação média são os menos propensos a participar de atividades, conforme Figura 31. Concluímos então que a hipótese testada é falsa, ou seja, indivíduos satisfeitos com a universidade são tão propensos a se envolver em atividades para o desenvolvimento sustentável quanto indivíduos não satisfeitos, mas mais propensos a se envolver do que indivíduos com satisfação média. 


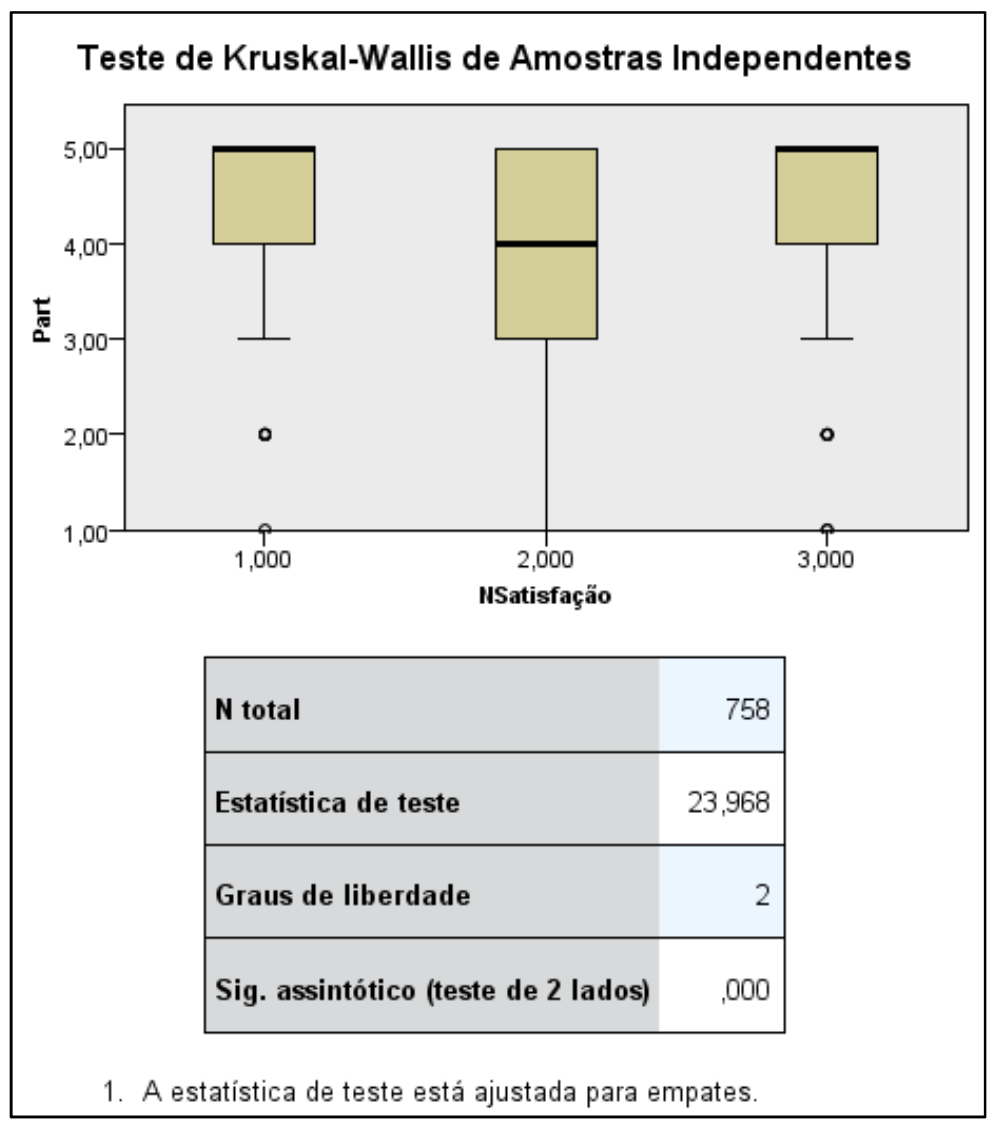

Figura 31: Instituição X - Hipótese 2 - Satisfação e Nível Participação Fonte: Elaboração própria

\subsubsection{3.}

\section{Hipótese 3}

A terceira hipótese, A percepção dos indivíduos sobre as ações para o desenvolvimento sustentável das universidades é influenciada pela atitude ou pelo comportamento, foi executada em três etapas, com intervalo de significância de 95\%:

1- Regressão linear com variável dependente a Percepção e como variável independente a Atitude.

Os resultados apontam uma correlação muito baixa, com $\mathrm{R}$ de 0,34 e $\mathrm{R}$ quadrado de 0,001 , ou seja, apenas $0,1 \%$ da variação da percepção é explicada na regressão. O resultado também apresentou significância alta da variável dependente Atitude, com sig. de 0,354, valor acima de 0,05 (a de significância da regressão), indicando que $B$ não é significantemente diferente de zero. 
2- Regressão linear com variável dependente a Percepção e como variável independente o Comportamento.

Os resultados apontam uma baixa correlação, com $R$ de 0,146 e $R$ quadrado de 0,021 , ou seja, apenas $2,1 \%$ da variação da percepção é explicada na regressão. Com relação aos coeficientes, a variável Comportamento apresentou Beta de 0,164 e sig. 0,000, indicando que B é significantemente diferente de zero (HAIR et al, 2005).

3- Regressão linear com variável dependente a Percepção e como variáveis independentes o Comportamento e a Atitude.

O resultado do teste apontou um $R$ de 0,146 e $R^{2}$ de 0,021, ou seja, apenas $2,1 \%$ da variação da regressão pode ser explicada pelas variáveis Atitude e Comportamento juntas. Quanto aos coeficientes, a Atitude apresentou alto valor de sig. $(0,859)$ e Comportamento, sig. de , 0000 .

Os resultados dos testes apontam que a atitude e o comportamento dos respondentes em relação a questões mais gerais sobre sustentabilidade não têm influência na percepção deles sobre as ações de sustentabilidade da universidade, já que apresentaram $R^{2}$ baixo, em comparação com o mínimo valor aceitável de 0,5 (HAIR et al., 2005), em todos os três casos testados. Assim, com 95\% de confiança podemos afirmar que a atitude e o comportamento não influenciam na percepção de alunos e docentes da amostra. 


\section{5 \\ Conclusão}

A transição para a sustentabilidade é tarefa que demanda muito trabalho e dedicação. O ensino de fundamentos do desenvolvimento sustentável permite que esses conhecimentos sejam disseminados e, de maneira gradual, aplicados entre pessoas e organizações. Neste contexto, a educação superior pode atuar como ferramenta habilitadora do desenvolvimento de práticas e competências que estimulem uma reflexão sobre a sustentabilidade e colocando os indivíduos como protagonistas deste processo.

A importância da atuação social de uma universidade na formação e profissionalização de indivíduos deve sustentar e promover conceitos e práticas para a sustentabilidade, de modo a criar ambientes propícios para experimentação e discussão. Assim, este trabalhou pretendeu investigar a percepção de docentes e alunos acerca das ações da universidade para o desenvolvimento sustentável em que estudam ou lecionam, de modo a identificar relações entre dimensões como percepção, satisfação e participação.

O estudo dos temas desenvolvimento sustentável e ensino superior permitiu identificar como a educação para o desenvolvimento sustentável foi construída ao longo do tempo e perceber como ainda estamos no início do processo de aprendizagem prática. Diversos autores estudados apontam para a convergência dos conceitos da sustentabilidade e concordam que o número de iniciativas práticas relatadas na academia ainda é insuficiente.

No âmbito político, diversas conferências internacionais para a Sustentabilidade já foram realizadas e continuam em discussão, com cada vez mais participantes. O tema também ganha relevância no meio empresarial, com a criação de índices nas Bolsas de Valores e indicadores de sustentabilidade para aplicação em empresas. Os vários acordos e declarações assinadas por universidades mostram que o tema é assunto corrente no acadêmico, onde instituições de ensino se comprometem a desenvolver iniciativas para o desenvolvimento sustentável. Assim, diversos artigos citam a tentativa de medir e mensurar a sustentabilidade no ambiente universitário, seja no aspecto do campus ou curricular (vide Tabela 4). 
Neste trabalho, a educação para o desenvolvimento sustentável é discutida e são levantados aspectos para serem incorporados às práticas existentes, como a integração das dimensões econômica, ambiental e social no currículo das universidades. Outro aspecto abordado é a necessidade de o ensino ser integral e holístico, orientado para a construção de alternativas, e da relevância de atividades práticas que transformem conhecimento em ação, para o desenvolvimento de competências e reflexões que promovam uma mudança de comportamento individual com ação local.

Foram apresentadas três dimensões de atuação para as instituições de ensino - campus, comunidade e educação, de modo que a educação praticada nas universidades vai além da educação formal de docentes, mas também se baseia no exemplo de práticas implantadas no campus e na relação com a comunidade, expondo como o ensino deve ser transdisciplinar e integrador.

Para atingir aos objetivos pretendidos realizou-se uma entrevista com uma representante da Instituição $X$ de modo a obter a percepção institucional acerca do tema. Também foi aplicado um questionário eletrônico para alunos e docentes, onde foram obtidas 919 respostas, das quais 758 acabaram sendo analisadas após a limpeza da base.

Os resultados e dados da Instituição X são apresentadas neste trabalho, nas dimensões relativas à atitude, ao comportamento e às percepções das dimensões campus, comunidade, educação e promoção, além da satisfação e da sua participação. As análises dos testes de hipóteses se utilizaram de ferramentas estatísticas como a análise fatorial e os testes não-paramétricos (MANOVA não-paramétrica e Teste de Kruskal-Wallis), e não consideraram a dimensão Promoção no modelo.

O primeiro teste de hipótese, que procurou validar o primeiro objetivo final deste trabalho, verificou se respondentes com percepção positiva das ações sustentáveis da universidade estão mais satisfeitos com as mesmas do que demais respondentes. Os testes foram executados para as dimensões Campus, Comunidade e Educação, além da Percepção geral, e podemos confirmar, com 95\% de significância, que quanto maior é a percepção positiva das ações, maior a satisfação das respondentes.

O resultado da primeira hipótese era esperado pelo pesquisador, já que havia a suposição inicial de que quanto mais se observa iniciativas para a sustentabilidade na universidade, maior é a satisfação por perceber que a universidade age com as ações necessárias para o desenvolvimento sustentável. 
Com o teste da segunda hipótese, analisamos o segundo objetivo final desta pesquisa. Nela, foi analisada a relação entre a satisfação dos respondentes e a propensão a participar de ações futuras da universidade para o desenvolvimento sustentável. De acordo com os resultados obtidos, a participação futura não depende da satisfação, já que observamos respondentes com intenção de participar de ações mesmo sem um alto índice de satisfação.

O resultado da segunda hipótese não foi o esperado pelo pesquisador, já que havia a suposição de que quanto mais satisfeito, maior é a intenção de participar em atividades para o desenvolvimento sustentável. A não confirmação do teste permite elaborar razões para o resultado obtido, como a suposição de que indivíduos insatisfeitos gostariam de se engajar em atividades justamente para suprir a insatisfação com a universidade, ou que indivíduos com satisfação mediana não têm alto comportamento e por isso são os menos propensos a participar.

A pesquisa também procurou identificar a atitude e o comportamento dos respondentes, e se estes fatores influenciam na percepção das ações realizadas pela universidade. O teste da terceira hipótese indicou que não há uma relação entre essas variáveis, e a percepção pode estar relacionada a outros fatores não explicados neste trabalho, como experiências prévias, sentimentos ou expectativas individuais.

O resultado da terceira hipótese também não era esperado pelo pesquisador, dada a suposição inicial de que a percepção sobre as ações de sustentabilidade era influenciada pela intenção e pela ação dos respondentes em relação ao desenvolvimento sustentável, já que quanto mais se têm consciência do tema, maior é a percepção existente das ações. Uma possível explicação do resultado é o fato de que as atitudes e comportamentos medidos terem sido referentes a questões genéricas, enquanto que a percepção das ações, além de seu caráter subjetivo, também era referente a aspectos específicos da Instituição $X$, sugerindo que esta não é contaminada por predisposições dos respondentes sobre o tema.

Por fim, foi realizada uma análise descritiva das respostas. De acordo os dados apresentados, a percepção de docentes da Instituição $X$ foi superior à de alunos em todas as dimensões (Campus, Comunidade, Educação e Promoção), apresentando médias superiores das variáveis consolidadas. 
Analisando cada dimensão individualmente, percebemos que o valor médio da atitude é superior ao do comportamento. Essa conclusão vai ao encontro de trabalhos acadêmicos na literatura (PAIVA et al., 2017) que indicam que a consciência de ações sustentáveis existe, mas ainda não foi traduzida em ações.

A dimensão Campus não obteve percepção geral positiva (média maior do que 4) na avaliação dos respondentes, com valor final de 3,86. Das 5 variáveis analisadas, apenas 2 não obtiveram média maior do que quatro: a questão relativa ao consumo de energia e água e a questão relativa aos investimentos sistemáticos no Campus, variável com alto índice de não observância. Uma possível explicação para a alta percepção dentro do Campus, é a existência de uma Agenda Ambiental com projetos dedicados à parte ambiental, aplicadas no Campus da universidade desde 2009.

Com relação à dimensão Comunidade, a variável Comunidade1 da Instituição $X$, referente à participação da universidade em ações promotoras do desenvolvimento social da comunidade em que está inserida, foi a única variável desta dimensão a ter média maior que 4 (4,04). Podemos especular que a baixa percepção positiva desta dimensão se deva pela dificuldade em participar de atividades, ou que os resultados dos projetos não sejam divulgados adequadamente.

A dimensão educação foi a única que apresentou variáveis com valores negativos (menores que 3). Para os alunos, as variáveis Educação4 e Educação5, relativas a quantidade de disciplinas que abordem 0 desenvolvimento sustentável e a quantidade de atividades práticas, foram respondidas negativamente, indicando que uma insuficiência curricular nestes quesitos. Tal resultado vai ao encontro do observado pela docente entrevistada, que sinalizou a diminuição de disciplinas socioambientais no currículo.

A percepção final, composta pela média das percepções do Campus, Comunidade e Educação, obteve valor médio de classificação, já que nenhuma dimensão individual apresentou valor negativo (menor do que 3) ou positivo (maior ou igual a 4). Apesar dos esforços relatados nas entrevistas para o desenvolvimento de ações para o desenvolvimento sustentável, o resultado indica que a Instituição $X$ poderia desenvolver mais atividades nas dimensões avaliadas, de modo a melhorar as percepções de alunos e docentes. De acordo os testes realizados por este trabalho (hipótese 1), com a melhoria das percepções, a satisfação tenderia a melhorar, o que pode ser de grande valia para a universidade. 
Com relação à dimensão Promoção, foi observado um alto percentual de respostas na opção 3 , relativa à indiferença. O resultado sugere a maior necessidade de divulgação de materiais e conteúdos por parte da universidade, já que a comunicação é uma das competências-chave para o desenvolvimento sustentável, conforme citado por Rieckmann (2010).

Com relação à satisfação, docentes e alunos da Instituição $X$ têm avaliações próximas, com média final geral de 3,36. Nenhum dos públicos apresentou médias positivas ou negativas, sugerindo que a satisfação de alunos e docentes é mediana.

A propensão à participação obteve média positiva geral para ambos os públicos. No entanto, apesar da maioria estar propensa a participar de ações para a sustentabilidade, apenas $17,8 \%$ dos respondentes já participam ou participaram de alguma atividade. Isso pode indicar que o número de atividades oferecidas na universidade é insuficiente ou pouco divulgados, já que os dados parecem apontar uma demanda reprimida para a participação.

Este trabalho não pretendeu esgotar o debate na academia sobre o desenvolvimento sustentável no ensino superior, nem de se aprofundar em como as instituições podem desenvolver suas ações nas dimensões do desenvolvimento sustentável. Interessa a esta pesquisa o estudo da percepção de alunos e docentes sobre ações para o desenvolvimento sustentável em universidades e se há relação entre percepção, satisfação e participação de stakeholders. O trabalho também pode ajudar a indicar quais áreas precisam de mais atenção, para que a educação possa produzir resultados positivos e regenerativos para a sociedade, principalmente nos aspectos ecológicos e sociais, de modo a obtermos um desenvolvimento que caminha para a sustentabilidade.

Como desdobramentos futuros, são sugeridas pesquisas que realizem testes complementares na base obtida, de forma a analisar os dados e testar as hipóteses da outra Instituição de Ensino, e comparar os resultados da Instituição $X$. Também é sugerida uma nova pesquisa com colaboradores administrativos das instituições, fornecedores e prestadores de serviços. Por fim, sugere-se também o aprofundamento do entendimento da percepção e da satisfação em cada dimensão, para identificar, para cada pergunta, quais são os direcionadores das respostas, de modo a entender os fatores de decisão dos respondentes da pesquisa. 


\section{Referências bibliográficas}

ABD-RAZAK, M. Z. et al. Campus Sustainability: Student's Perception on Campus Physical Development Planning in Malaysia. Procedia Engineering 20. p. 230-237. 2011.

ALCARAZ, J. M.; THIRUVATTAL, E. An Interview With Manuel Escudero The United Nations' Principles for Responsible Management Education: A Global Call for Sustainability. Academy of Management Learning \& Education, v. 9, n. 3, p. 542-550, 2010.

ANAND, C. K.; BISAILLON, V.; WEBSTER, A.; AMOR, B. Integration of sustainable development in higher education - a regional initiative in Quebec (Canada), Journal of Cleaner Production, v. 108, p. 916-923, 2015.

ANTUNES, C. A avaliação da aprendizagem escolar. Fascículo 11. Petrópolis, RJ. Vozes, 2001.

ARAÚJO, G. C.; BUENO, M.; SOUSA, A.; MEDONÇA, P. Sustentabilidade Empresarial: Conceito e Indicadores, III CONVIBRA - 24 a 26 de novembro de 2006.

ARAÚJO, W. C. O.; INOMATA, D. O.; RADOS, G. J. V. Desenvolvimento Sustentável Empresarial: $O$ Uso da Gestão da Informação. Rev. digit. bibliotecon. cienc. inf., Campinas, SP, v. 12, n. 3, p. 119-135, set/dez. 2014. ISSN 1678-765X. Disponível em: <http://www.sbu.unicamp.br/seer/ojs/index.php/rbci>. Acesso em: 31 maio. 2017

ÁVILA, L. V.; MADRUGA, L. R.; BEURON, T. A. PLANEJAMENTO E SUSTENTABILIDADE: O CASO DAS INSTITUIÇÕES FEDERAIS DE ENSINO SUPERIOR, Revista de Gestão Ambiental e Sustentabilidade, 2016.

um Modelo de Universidade Verde, XL EnANPAD, 2016 . Universidade Sustentável: Contribuições para

BARBIERI, J. C.; SILVA, D. Desenvolvimento sustentável e Educação Ambiental: uma trajetória comum com muitos desafios. Revista de Administração Mackenzie, art. 89, v. 12, n. 3, p. 51-82, 2011. ; VASCONCELOS, I. F. G.; ANDREASSI, T.; VASCONCELOS, F. C. Inovação e Sustentabilidade: Novos Modelos e Proposições, 2010.

BARCELONA DECLARATION, 2004. Disponível em: <http://www.idd.ie/barcelona/index.htm>. Acesso em: 05/01/2018.

BENITES, L. L. L.; POLO, E. F. A Sustentabilidade Como Ferramenta Estratégica Empresarial: Governança Corporativa E Aplicação Do Triple Bottom Line Na Masisa, Rev. Adm. UFSM, Santa Maria, Edição Especial, v. 6, p. 827841, Mai. 2013 
BIASUTTI, M.; FRATE, S. A validity and reliability study of the Attitudes toward Sustainable Development scale, Environmental Education Research, v. 23, n. 2, p. 214-230, 2017.

BOURSCHEIDT, D. M.; DALCOMUNI, S. M. Do crescimento econômico ao desenvolvimento sustentável: aspectos conceituais e marcos importantes, 2010.

BRANDÃO, C. R. O que é educação. São Paulo: Brasiliense, 2007.

BRUNSTEIN, J.; RODRIGUES, A. L. Gestores e Sustentabilidade: A Difícil Tradução do Significado para a Ação Competente. Revista Alcance, v. 21, n. 01, Jan./Mar. 2014.

CARTA UNIVERSITÁRIA PARA O DESENVOLVIMENTO SUSTENTÁVEL. Programa Copérnico. Geneva: $1994 . \quad$ Disponível em: $<$ http://www.eticus.com/documentacao.php?tema=1\&doc=12>. Acesso em: 21/02/2018.

CARVALHO, N. L. et al. DESENVOLVIMENTO SUSTENTÁVEL $X$ DESENVOLVIMENTO ECONÔMICO, Revista Monografias Ambientais. Santa Maria, v. 14, n. 3, p. 109-117. Set-Dez. 2015.

CLOSS, L. Q.; ANTONELLO, C. S., teoria da aprendizagem transformadora: contribuições para uma educação gerencial voltada para a sustentabilidade. RAM, REV. ADM. MACKENZIE. SÃO PAULO, SP. Edição Especial. v. 15(3), 221-252, Maio-Jun. 2014.

CLUGSTON, R. M.; CALDER, W. Critical dimensions of sustainability in higher education. Sustainability and University Life, v. 5, p. 31-46, 1999.

COELHO, A. S. C.; PEREIRA, V. L. D. V.; LEZANA, A. G. R. Sustentabilidade empresarial e a dimensão da exeqüibilidade, Navus - Revista de Gestão e Tecnologia. Florianópolis, SC, v. 1, n. 1, p. 67-81, Jul./Dez. 2011.

CORTESE, A. D. The critical role of higher education in creating a sustainable future. Planning for higher education, v. 31, n. 3, p. 15-22, 2003.

COSTANZA, R. (Editor), Ecological Economics: The Science and Management of Sustainability. Columbia,University Press, New York, NY, 1991.

DABIJA, D.-C.; POSTELNICU, C.; DINU, V.; MIHĂILĂ, A. Stakeholders' perception of sustainability orientation within a major Romanian University. International Journal of Sustainability in Higher Education, v. 18, Issue: 4, p. 533-553, 2017.

DELAI, I.; TAKASHASHI, S. Uma proposta de modelo de referência para mensuração da sustentabilidade corporativa, RGSA - Revista de Gestão Social e Ambiental. v. 2, n. 1, p. 19-40 Jan-Abr. 2008.

DIAS, S. L. F. G.; HERRERA, C. B.; CRUZ, M. T. S. Desafios (e dilemas) para inserir "Sustentabilidade" nos currículos de Administração: um estudo de caso. Revista de Administração Mackenzie, v. 14, n. 3, p. 119-153, 2013. 
DRAHEIN, A. D.; DAGOSTIN, H.; LIMA, E. P. Auditoria das práticas de sustentabilidade nas operações de serviço de instituições de ensino superior, XXXV ENEGEP, Outubro, 2015.

ELKINGTON, J. Canibais com garfo e faca. São Paulo: Makron Books, 2001.

FEIL, A. A.; SCHREIBER, D. Sustentabilidade e Desenvolvimento Sustentável: Desvendando as Sobreposições e Alcances de Seus Significados. Cadernos EBAPE.BR, v. 15, n. 3, p. 667-681, 2017.

FRANCO, I. T.; TEIXEIRA, M. G.; AZEVEDO, D. B.; MOURA-LEITE, R. C. A Inserção da Temática de Sustentabilidade na Formação de Futuros Gestores: como os Professores se Deparam com o Assunto? Administração: Ensino e Pesquisa, v. 16, n. 3, p. 571-607, 2015.

FREIRE, P. Desafios da educação de adultos ante a nova reestruturação tecnológica. Pedagogia da Indignação: cartas pedagógicas e outros escritos. São Paulo: UNESP, 2003.

GADOTTI, M. Perspectivas Atuais da Educação, 2000.

GRAZ DECLARATION, 2005. Disponível em: <https://www.iauhesd.net/sites/default/files/documents/2005 -

_graz_declaration_on_committing_universities_to_sustainable_development_fr.p df $>$.

GUERRA, J.; SCHMIDT, L. Making Wishful Thinking a Reality - From SDGS to COP21. Ambient. soc., São Paulo, v. 19, n. 4, p. 197-214, Dec. 2016.

GUIMARÃES, R.; FONTOURA, Y. Desenvolvimento sustentável na Rio+20: discursos, avanços, retrocessos e novas perspectivas. Cadernos EBAPE.BR, v. 10, n. 3, p. 508-532, 2012.

GUIMARÃES, S. S. M.; TOMAZELLO, M. G. C., A formação universitária para o ambiente: educação para a sustentabilidade. Ambiente e Educação. Rio Grande, p. 55-71, 2003.

HALLIFAX DECLARATION, 1991. Disponível em: <https://www.iauhesd.net/sites/default/files/documents/rfl_727_halifax_2001.pdf>.

HAIR, Jr., J. F.; ANDERSON, R. E.; TATHAM. R. L. BLACK, W. C. (2005). Análise Multivariada de dados. Tradução: Adonai Schlup Sant'Anna e Anselmo Chaves Neto. 5.ed. Porto Alegre: Bookman. p. 593.

HEEREN, A. J. et al. Is sustainability knowledge half the battle?: An examination of sustainability knowledge, attitudes, norms, and efficacy to understand sustainable behaviours, International Journal of Sustainability in Higher Education, v. 17, Issue: 5, p. 613-632, 2016.

JACOBI, P. R.; RAUFFLET, E.; ARRUDA, M. P. Educação para a sustentabilidade nos cursos de administração: reflexão sobre paradigmas e práticas. RAM, REV. ADM. MACKENZIE. Edição Especial. SÃO PAULO. SP. v. 12, n. 3, Maio/Jun. 2011. 
JUNIOR, F. H.; DIAS, B. G.; ZELLMEISTER, L. M.; BRINHOLI, C. F. A Sustentabilidade no Ensino de Administração: Proposta de um Currículo Básico para o Curso de Graduação, XXXVIII EnANPAD, 2014.

KEINONEN, T. et al. Higher education students' perceptions of environmental issues and media coverage. Discourse and Communication for Sustainable Education. v. 7, p. 5-22. 2016.

KIPERSTOK, A. et al. Inovação como requisito do Desenvolvimento Sustentável. REAd. Revista Eletrônica de Administração, v. 8, n. 6, p. 1-20, 2002.

KRAEMER, M. E. P. Responsabilidade Social Corporativa: uma contribuição das empresas para o desenvolvimento sustentável, RECADM, v. 4, n. 1, maio/2005.

LADEIRA, W. J.; SANTINI, F. O.; ARAÚJO, C. F. Instituições de Ensino Superior como agentes de sustentabilidade: validação de um instrumento quantitativo. Caderno Profissional de Administração - UNIMEP, v. 5, n. 1, 2015.

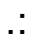
Práticas sustentáveis nas instituições de ensino superior: uma proposta de taxonomia baseada na percepção ambiental dos alunos do curso de administração. Administração: Ensino e Pesquisa. v. 13, n. 4. 2012.

LANDIM, C. M. M. P. F. Educação à distância: algumas considerações. Rio de Janeiro: s.n.1997.

LARA, L. G. A.; OLIVEIRA, S. A. A ideologia do crescimento econômico e o discurso empresarial do desenvolvimento sustentável. Cad. EBAPE.BR. Rio de Janeiro, v. 15, n. 2, p. 326-348, June 2017.

LARA, P. T. R. Sustentabilidade em instituições de ensino superior, REMOA/UFSM, n. 7, p. 1646-1656, Mar-Jun, 2012.

LÉLÉ, S. M. Sustainable development: a critical review. World Development, Montreal, v. 19, n. 6, p. 607-621, June 1991.

LIMA, G. C. O discurso da sustentabilidade e suas implicações para a educação. Revista Ambiente e Sociedade, São Paulo, v. 6, n. 2, 2003

LIMA, P. V. P. S.; KHAN, A. S. Formação superior: uma prioridade da educação para a sustentabilidade no Brasil, p. 169-192. In: Responsabilidade social das empresas: a contribuição das universidades, v. 8. São Paulo: Peirópolis, Instituto Ethos, 2011.

LOCATELLI, P. A. Consumo sustentável. Revista de Direito Ambiental. São Paulo, v. 5, n. 19, p. 297-300, jul.-set. 2000.

LUNENBURG DECLARATION, 2001. Disponível em: <https://www.iauhesd.net/sites/default/files/documents/2001_-_the_luneburg_declaration_fr.pdf $>$.

MARAGAKIS, A.; DOBBELSTEEN, A. v. d.; MARAGAKIS, A. Stakeholders Perceptions of a Universal Sustainability Assessment in Higher Education - A Review of Empirical Evidence. International Journal of Higher Education. v.. 5, n. 4, 2016. 
MARCOMIN, F. E.; SILVA, A. D. V. - A sustentabilidade no ensino superior brasileiro: alguns elementos a partir da prática de educação ambiental na Universidade, CONTRAPONTOS - Itajaí. v. 9, n. 2, p. 104-117. mai/ago 2009.

MAROCO, J. 2007. Análise estatística com utilização do SPSS, Lisboa, Edições Sílabo.

MATOS, R. A.; ROVELLA, S. B. C., Do crescimento econômico ao Desenvolvimento Sustentável: Conceitos em evolução. Revista no 3 - Jan/Jul 2010.

MAZZALI, L.; FERNANDEZ, S. A. F.; NOGUEIRA, A. G. Estratégia competitiva no ensino superior: o desenvolvimento de competências distintivas na busca pela diferenciação. BASE - Revista de Administração e Contabilidade da UNISINOS, v. 2, n. 3, p. 133-143, 2005.

MELO, E. C.; BRUNSTEIN, J. Experiências docentes de educação para sustentabilidade na sala de aula de administração. Pretexto. 2014. Belo Horizonte. v. 15, NE, p. 116-135. ISSN 1517-672.

MELO, P. T. N. B.; SALLES, H. K.; BELLEN, H. M. V. Quadro institucional para o desenvolvimento sustentável: o papel dos países em desenvolvimento com base na análise crítica do discurso da Rio+20. Cadernos EBAPE.BR, v. 10, n. 3, p. 701-720, 2012.

MICANGELI, A. et al. Attitudes toward Sustainability and Green Economy Issues Related to Some Students Learning Their Characteristics: A Preliminary Study, Sustainability, v. 6, p. 3484-3503; doi:10.3390/su6063484, 2014.

MICHALOS, A. C.; CREECH, H.; MCDONALD, C.; KAHLK, M. H. Measuring Knowledge, Attitudes and Behaviours towards Sustainable Development: Two Exploratory Studies, International Institute for Sustainable Development (IISD), 2009.

MÜLLER-CHRIST, G. et al. The Role of Campus, Curriculum, and Community in Higher Education for Sustainable Development - a Conference Report. In: Journal of Cleaner Production. v. 62, n. 1, p. 134-137. January 2014.

OLIVEIRA, E. W. M.; SOLA, D. D. L. A institucionalização do pilar econômico da sustentabilidade e a sub valorização dos pilares social e ambiental. Revista Capital Científico - Eletrônica, v. 11, n. 3, p. 43-57, 2013.

OLIVEIRA, J. P. Rio+20: What we can learn from the process and what is missing. CADERNOS EBAPE.BR, v. 10, n. 3, p. 492-507, 2012.

OLIVEIRA, L. R. et al. Sustentabilidade: da evolução dos conceitos à implementação como estratégia nas organizações, Produção, v. 22, n. 1, p. 7082, jan./fev. 2012

ORSIOLLI, T. A. E.; NOBRE, F. S. Empreendedorismo Sustentável e Stakeholders Fornecedores: Criação de Valores para o Desenvolvimento Sustentável. RAC, Rio de Janeiro, v. 20, n. 4, art. 6, p. 502-523, Jul./Ago. 2016. 
PACHECO JUNIOR, W. et al. Sustentabilidade empresarial e a dimensão da exeqüibilidade, Navus - Revista de Gestão e Tecnologia., Florianópolis, SC, v. 1, n. 1, p. 67-81, Jul./Dez. 2011.

PAIVA, M. B. M.; OLIVEIRA, L. V. C.; ROMERO, C. B. A.; GUIMARÃES, D. B. Consumer Myopia: Uma Análise do Gap entre Atitude e Comportamento Sustentável, Rev. Adm. UFSM, Santa Maria, Ed. Especial. v. 10, p. 26-43, 2017.

PALMA, L. C.; ALVES, N. B.; SILVA, T. N. Educação para a sustentabilidade: a construção de caminhos no Instituto Federal de Educação, Ciência e Tecnologia do Rio Grande do Sul (IFRS), RAM, REV. ADM. MACKENZIE, Edição Especial. SÃO PAULO, SP. v. 14, n. 3, p. 83-118. Maio/Jun. 2013

PEDROSO, M. Casos Sustentáveis. GV EXECUTIVO, v. 6, n. 2. Mar./Abr. 2007.

PENEDO, A. S. T.; SILVEIRA-MARTINS, E.; PEREIRA, V. S. The Economic Growth to Sustainable Development. Desafio Online, v. 4, n. 3, p. 36-51, 2016.

PENNA, C. G. O estado do Planeta: Sociedade de consumo e degradação ambiental. Rio de Janeiro: Record. p. 252. 1999.

PEREIRA, A. S. Educação Superior e Sustentabilidade: Um estudo sobre a percepção dos atores do Campus Alto Paraopeba / UFSJ / MG. Lavras, 2013. 155p. Dissertação (Mestrado em Administração) - Universidade Federal de Lavras, 2013.

PEREIRA, S. S.; CURI, R. C. Meio ambiente, impacto ambiental e desenvolvimento sustentável: conceituações teóricas sobre o despertar da consciência ambiental. Reunir: Revista de Administração, Contabilidade e Sustentabilidade, v. 2, n. 4, p. 35-57, 2012.

PIRES, F.; LUCAS, A. C.; FISCHER, A. L. O papel das competências individuais na construção da sustentabilidade. Pensamento \& Realidade, v. 27, n. 4, p. 92$111,2012$.

PONTES, A. S. M.; CARNEIRO, C. Sustentabilidade e educação superior: análise das ações de sustentabilidade de duas Instituições de Ensino Superior de Santa Catarina. Rev. Adm. UFSM, Santa Maria, Edição Especial, v. 8, p. 84103, Ago. 2015.

PRME-ONU. PRME - Principles for a Responsible Management Education, United Nations. Disponível em: <http://www.unprme.org/>. Acesso em: Janeiro 2018.

REIS, J. A. F. D.; MARTINS, R. R. R.; GAIO, J.; LOHMANN, L. M. Estrutura do ensino superior brasileiro: um diagnóstico estratégico societário. Revista Brasileira de Estratégia, v. 7, n. 1, p. 88-99, 2014.

RIECKMANN, M. Future-oriented higher education: Which key competencies should be fostered through university teaching and learning? Futures, v. 44, n. 2, p. $127-135,2010$. 
RODRIGUES, K. F.; RIPPEL, R. Desenvolvimento Sustentável e Técnicas de Mensuração, Revista de Gestão Ambiental e Sustentabilidade - GeAS. v. 4, n. 3. Setembro/Dezembro. 2015.

RODRIGUES, L. F.; FILHO, N. P. A., Indicadores de Sustentabilidade para Instituições de Ensino do PRME CHAPTER BRASIL, 2016.

RODRIQUEZ, S. I.; ROMAN, M. S.; STURHAHN, S. H.; TERRY. E. H. Sustainability Assessment and Reporting for the University of Michigan's Ann Arbor Campus. University Master's Project. University of Michigan: Ann Arbor: 1-396. 2002.

ROMEIRO, A. R. Desenvolvimento sustentável: uma perspectiva econômicoecológica, 2012.

SACHS, J. Common wealth: economics for a crowded planet. New York, Penguin Press. 2008.

SARTORI, S.; LATRÔNICO, F.; CAMPOS, L. M. S. Sustentabilidade e desenvolvimento sustentável: uma taxonomia no campo da literatura. Revista Ambiente \& Sociedade. São Paulo v. XVII, n. 1. p. 1-22. Jan-Mar. 2014.

SEATTER, C. S.; CEULEMANS, K. Teaching Sustainability in Higher Education: Pedagogical Styles that Make a Difference. Canadian Journal of Higher Education. v. 47, Issue 2, p. 47-70, 24p. 2017.

SHARMA, U.; KELLY, M. Students' perceptions of education for sustainable development in the accounting and business curriculum at a business school in New Zealand, Meditari Accountancy Research, v. 22, Issue: 2, p.130-148. 2014.

SHEIKH, S. N. S.; AZIZ, A. A.; YUSOF, K. M. Perception on Sustainable Development among New First Year Engineering Undergraduates. Procedia Social and Behavioral Sciences. v. 56, p. 530-536. 2012.

SILVA, E. A.; FREIRE, O. B. L.; SILVA, F. Q. P. O. Indicadores de sustentabilidade como instrumentos de gestão: uma análise da GRI, ETHOS e ISE. Revista de Gestão Ambiental e Sustentabilidade, v. 3, n. 2, p. 130-148, 2014.

SILVA, M. E. A estratégia de responsabilidade social e a transição para sustentabilidade. Teoria e Prática em Administração, v. 4 n. 1, 2014, pp. 56-77 A prática responsável e as estruturas curriculares das instituições de ensino superior do Recife/PE no curso de administração sob a ótica da educação para a sustentabilidade. Administração: Ensino e Pesquisa. Rio de Janeiro. v. 13, n. 1, p. 77-109. jan/fev/mar 2012.

.; ALVES, A. P. F.; VOLKMER, G. Está chovendo no molhado? A visão acadêmica sobre o desenvolvimento sustentável em um contexto de crise. Revista de Administração da UFSM, v. 7, n. esp, p. 70-87, 2014.

SILVA, S. S.; REIS, R. P.; AMÂNCIO, R. Conceitos atribuídos à sustentabilidade em organizações de diferentes setores. Revista de Ciências da Administração, v. 16, n. 40, p. 90-103, 2014. 
SOUZA, S.; SILVA, A. R. L.; SILVA JÚNIOR, A. O processo de formação de estratégias organizacionais em uma IES: um estudo de caso em uma instituição privada. Revista Alcance, v. 18, n. 3, p. 341-355, 2011.

STEPHENS, J. C. et al. Higher education as a change agent for sustainability in different cultures and contexts. International Journal of Sustainability in Higher Education, v. 9, n. 3, p. 317-338, 2008.

TALLOIRES DECLARATION (1990). Disponível em: <http://ulsf.org/wpcontent/uploads/2015/06/TD.pdf>.

TAUCHEN, J.; BRANDLI, L. L. A gestão ambiental em instituições de ensino superior: modelo para implantação em campus universitário. Gest. Prod., São Carlos, v. 13, n. 3, p. 503-515, Dec. 2006.

THOMASHOW, M. The Nine Elements of a Sustainable Campus. Sustainability: The Journal of Record. v. 7(3), 2014.

TILBURY, D. Higher education for sustainability: A global overview of commitment and progress. Higher education in the world. v. 4, p. 18-28. 2011.

TRIGO, A. G. M.; LIMA, R. S. X.; OLIVEIRA, D. M. Índice de Sustentabilidade Socioambiental no Ensino, Rev. Adm. UFSM, Santa Maria, Edição Especial, v. 7, p. 07-22, NOV. 2014.

UNESCO. Education for Sustainable Development, 2012. Disponível em: $<$ https://en.unesco.org/themes/education-sustainable-development>. Acesso em: 30 de novembro. 2017.

UNESCO. UNESCO and Sustainable Development. 2005. Disponível em: $<$ http://unesdoc.unesco.org/images/0013/001393/139369e.pdf>. Acesso em: 30 de novembro. 2017.

VAN BELLEN, H. M. Indicadores de sustentabilidade - um levantamento dos principais sistemas de avaliação, Cadernos EBAPE.BR, v. II, n. 1. Março 2004.

VELAZQUEZ, L. et al. Sustainable university: what can be the matter? Journal of Cleaner Production, v. 14, n. 9, p. 810-819, 2006.

VIEGAS, C. V.; BOND, A. J.; SELLITTO, M. An International Review of Sustainability in Higher Education Studies: A Messy Concept with Contradictory Attitudes. Cleaner Production Towards A Sustainable Transition. São Paulo. Brazil. 2015.

VILHA, A. M.; CARVALHO, R. Q. Desenvolvimento de novas competências e práticas de gestão da inovação voltadas para o desenvolvimento sustentável: estudo exploratório da Natura. Cadernos EBAPE.BR, v. 3, n. Ed. Especial, p. 115, 2005.

WARDEN III, K. R. Faculty and Staff Perceptions of Sustainability Initiatives on Tree Arkansas Two-Year College Campuses. Teses and Dissertations. 306. Fayetteville, 2012. 78p. Dissertação (Master of Education in Educational Leadership) - University of Arkansas. 
WARKEN, I. L. M.; HENN, V. J.; ROSA, F. S. Gestão da sustentabilidade: um estudo sobre o nível de sustentabilidade socioambiental de uma Instituição Federal de Ensino Superior. Revista de Gestão, Finanças e Contabilidade, ISSN 2238-5320, UNEB, Salvador, v. 4, n. 3, p. 147-166, set./dez., 2014.

WIEK, A.; WITHYCOMBE, L.; REDMAN, C. L. Key competencies in sustainability: a reference framework for academic program development. Sustainability Science, v. 6, n. 2, p. 203-218, 2011. 


\section{Anexo 1}

Figura 1. Teste de Normalidade - Instituição X

Testes de Normalidade

\begin{tabular}{|c|c|c|c|c|c|c|}
\hline & \multicolumn{3}{|c|}{ Kolmogorov-Smirnov ${ }^{a}$} & \multicolumn{3}{|c|}{ Shapiro-Wilk } \\
\hline & Estatística & df & Sig. & Estatística & df & Sig. \\
\hline Atitude1 &, 310 & 758 &, 000 & ,668 & 758 &, 000 \\
\hline Atitude 2 &, 510 & 758 &, 000 & ,361 & 758 &, 000 \\
\hline Atitude3 & ,281 & 758 &, 000 &, 738 & 758 &, 000 \\
\hline Atitude 4 & .272 & 758 & .000 &, 751 & 758 & .000 \\
\hline Atitude 5 &, 387 & 758 &, 000 & 619 & 758 &, 000 \\
\hline Atitude6 & .262 & 758 & .000 & 836 & 758 &, 000 \\
\hline Comportamento1 &, 267 & 758 &, 000 &, 843 & 758 &, 000 \\
\hline Comportamento 2 &, 514 & 758 &, 000 & ,358 & 758 &, 000 \\
\hline Comportamento 3 & .226 & 758 & .000 & 819 & 758 &, 000 \\
\hline Comportamento 4 & ,228 & 758 &, 000 & ,839 & 758 &, 000 \\
\hline Comportamento5 & 207 & 758 &, 000 & 905 & 758 &, 000 \\
\hline Campus1 &, 247 & 758 &, 000 & 806 & 758 &, 000 \\
\hline Campus2 & ,178 & 758 &, 000 & ,909 & 758 &, 000 \\
\hline Campus 3 & 259 & 758 &, 000 &, 782 & 758 & .000 \\
\hline Campus 4 & ,307 & 758 & , 000 & ,737 & 758 &, 000 \\
\hline Campus5 & ,195 & 758 &, 000 &, 892 & 758 &, 000 \\
\hline Comunidade1 & .228 & 758 &, 000 & 832 & 758 & .000 \\
\hline Comunidade 2 & ,221 & 758 &, 000 & ,884 & 758 &, 000 \\
\hline Comunidade 3 & ,231 & 758 &, 000 & 892 & 758 &, 000 \\
\hline Comunidade 4 & .227 & 758 & .000 & 867 & 758 &, 000 \\
\hline Comunidade5 & 189 & 758 &, 000 & ,898 & 758 &, 000 \\
\hline Educação1 &, 286 & 758 & .000 &, 732 & 758 &, 000 \\
\hline Educação2 & .243 & 758 & .000 & .825 & 758 & .000 \\
\hline Educação3 &, 269 & 758 &, 000 &, 861 & 758 &, 000 \\
\hline Educação 4 & 199 & 758 & .000 & 891 & 758 &, 000 \\
\hline Educação5 & .176 & 758 & .000 & 901 & 758 & .000 \\
\hline Educação6 & 207 & 758 &, 000 & 890 & 758 &, 000 \\
\hline Promoção1 & 192 & 758 & .000 & 909 & 758 & .000 \\
\hline Promoção2 & 191 & 758 &, 000 & ,903 & 758 &, 000 \\
\hline Satisfação1 &, 280 & 758 &, 000 & 870 & 758 &, 000 \\
\hline Satisfação2 & .232 & 758 & .000 & 895 & 758 & .000 \\
\hline Satisfação 3 &, 256 & 758 &, 000 & 887 & 758 &, 000 \\
\hline Participação3 & .272 & 758 & .000 & .774 & 758 & .000 \\
\hline
\end{tabular}

a. Correlação de Significância de Lilliefors 
Figura 2. Testes de Normalidade das variáveis criadas - Instituição X

Testes de Normalidade

\begin{tabular}{|l|r|r|r|r|r|r|}
\hline & \multicolumn{4}{|c|}{ Kolmogorov-Smirnova } & \multicolumn{3}{|c|}{ Shapiro-Wilk } \\
\cline { 2 - 7 } & Estatística & \multicolumn{1}{c|}{ df } & \multicolumn{1}{c|}{ Sig. } & Estatística & \multicolumn{1}{c|}{ df } & \multicolumn{1}{c|}{ Sig. } \\
\hline Atitude &, 146 & 758 &, 000 &, 897 & 758 &, 000 \\
Comportamento &, 083 & 758 &, 000 &, 979 & 758 &, 000 \\
Campus &, 090 & 758 &, 000 &, 965 & 758 &, 000 \\
Comunidade &, 075 & 758 &, 000 &, 977 & 758 &, 000 \\
Educação &, 071 & 758 &, 000 &, 975 & 758 &, 000 \\
Promoção &, 136 & 758 &, 000 &, 950 & 758 &, 000 \\
Percepção &, 044 & 758 &, 001 &, 989 & 758 &, 000 \\
Satisfação &, 136 & 758 &, 000 &, 963 & 758 &, 000 \\
\hline
\end{tabular}

a. Correlação de Significância de Lilliefors

Figura 3. Teste de Levine - fator PercepçãoNível - Instituição X

Teste de caixa de igualdade de matrizes

de covariância ${ }^{a}$

\begin{tabular}{|l|r|}
\hline M de Box & 1032,039 \\
$Z$ & 2,902 \\
df1 & 342 \\
df2 & 666512,144 \\
Sig. &, 000 \\
\hline
\end{tabular}

Testa a hipótese nula

de que as matrizes de

covariância observadas

das variáveis

dependentes são iguais

entre grupos.

a. Design: Interceptação

+ PercepçãoNivel 
Figura 4. Hipótese 1 - Campus - Rastreamento de Pilai - Instituição X

Fatores entre assuntos
\begin{tabular}{|rl|r|}
\hline & & \multicolumn{1}{|c|}{$\mathrm{N}$} \\
\hline NCampus & 1 & 453 \\
& 2 & 244 \\
& 3 & 61 \\
\hline
\end{tabular}

Testes multivariáveis ${ }^{a}$

\begin{tabular}{|ll|r|r|r|r|r|}
\hline Efeito & & \multicolumn{1}{c|}{ Valor } & \multicolumn{1}{c|}{$\begin{array}{c}\text { df de } \\
\text { hipótese }\end{array}$} & \multicolumn{1}{c|}{ Erro df } & \multicolumn{1}{c|}{ Sig. } \\
\hline Interceptação & Rastreamento de Pillai &, 873 & $1289,445^{\mathrm{b}}$ & 4,000 & 752,000 &, 000 \\
& Lambda de Wilks &, 127 & $1289,445^{\mathrm{b}}$ & 4,000 & 752,000 &, 000 \\
& Rastreamento de & 6,859 & $1289,445^{\mathrm{b}}$ & 4,000 & 752,000 &, 000 \\
& Hotelling & 6,859 & $1289,445^{\mathrm{b}}$ & 4,000 & 752,000 &, 000 \\
& Maior raiz de Roy &, 758 & 114,916 & 8,000 & 1506,000 &, 000 \\
\hline NCampus & Rastreamento de Pillai &, 249 & $189,004^{\mathrm{b}}$ & 8,000 & 1504,000 &, 000 \\
& Lambda de Wilks & 2,994 & 281,076 & 8,000 & 1502,000 &, 000 \\
& Rastreamento de & 2,985 & $561,931^{\mathrm{C}}$ & 4,000 & 753,000 &, 000 \\
\hline
\end{tabular}

a. Design: Interceptação + NCampus

b. Estatística exata

c. A estatística é um limite superior em $F$, que gera um limite inferior no nível de significância.

Figura 5. Hipótese 1 - Campus - Kruskal-Wallis - Instituição X

\begin{tabular}{|ll|r|r|}
\multicolumn{4}{c}{ Classificaçöes } \\
\hline NCampus & \multicolumn{1}{c|}{$\mathrm{N}$} & $\begin{array}{c}\text { Postos de } \\
\text { média }\end{array}$ \\
\hline Sat_Cam & 1 & 453 & 451,83 \\
& 2 & 244 & 301,21 \\
& 3 & 61 & 155,51 \\
& Total & 758 & \\
\hline CA1 & 1 & 453 & 495,57 \\
& 2 & 244 & 234,04 \\
& 3 & 61 & 99,39 \\
& Total & 758 & \\
\hline CA2 & 1 & 453 & 482,98 \\
& 2 & 244 & 257,37 \\
& 3 & 61 & 99,58 \\
& Total & 758 & \\
\hline CA3 & 1 & 453 & 483,58 \\
& 2 & 244 & 258,03 \\
& 3 & 61 & 92,46 \\
& Total & 758 & \\
\hline
\end{tabular}

Estatísticas de teste ${ }^{a, b}$

\begin{tabular}{|l|r|r|r|r|}
\hline & Sat_Cam & \multicolumn{1}{c|}{ CA1 } & \multicolumn{1}{c|}{ CA2 } & \multicolumn{1}{c|}{ CA3 } \\
\hline Qui-quadrado & 162,930 & 339,163 & 339,164 & 329,621 \\
df & 2 & 2 & 2 & 2 \\
Significância Sig. &, 000 &, 000 &, 000 &, 000 \\
\hline
\end{tabular}

a. Teste Kruskal Wallis

b. Variável de Agrupamento: NCampus 
Figura 6. Hipótese 1 - Campus - Médias das Ordens - Instituição X

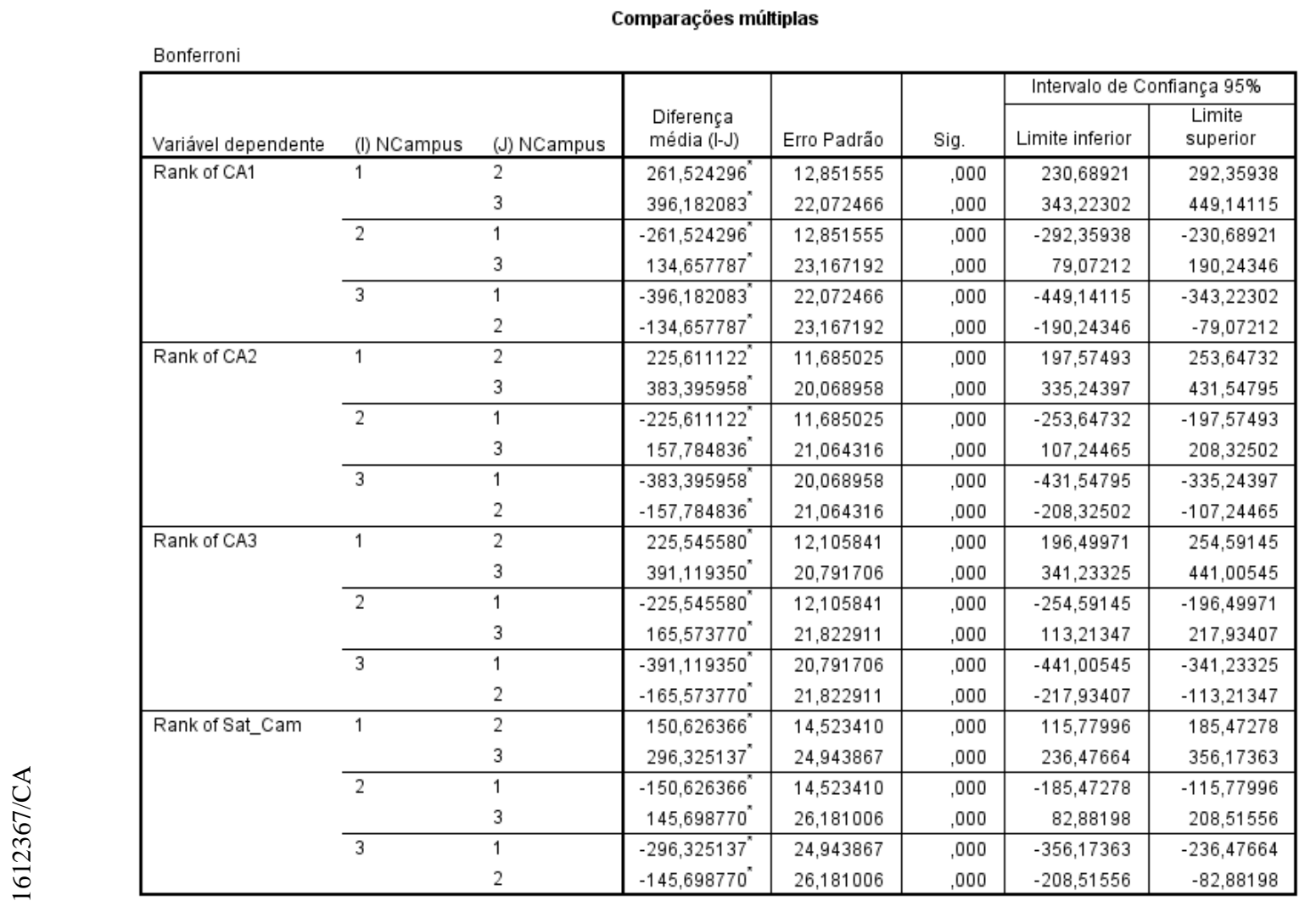

*. A diferença média é significativa no nível 0.05

Figura 7. Hipótese 1 - Comunidade - Rastreamento de Pilai - Instituição X

Fatores entre assuntos

\begin{tabular}{|ll|l|}
\hline & N \\
\hline NComunidade & 1 & 325 \\
& 2 & 313 \\
& 3 & 120 \\
\hline
\end{tabular}

Testes multivariáveis ${ }^{a}$

\begin{tabular}{|c|c|c|c|c|c|c|}
\hline Efeito & & Valor & Z & $\begin{array}{c}\text { df de } \\
\text { hipótese }\end{array}$ & Erro df & Sig. \\
\hline \multirow[t]{4}{*}{ Interceptação } & Rastreamento de Pillai &, 939 & $2871,987^{b}$ & 4,000 & 752,000 &, 000 \\
\hline & Lambda de Wilks & ,061 & $2871,987^{\mathrm{b}}$ & 4,000 & 752,000 &, 000 \\
\hline & $\begin{array}{l}\text { Rastreamento de } \\
\text { Hotelling }\end{array}$ & 15,277 & $2871,987^{\text {b }}$ & 4,000 & 752,000 &, 000 \\
\hline & Maior raiz de Roy & 15,277 & $2871,987^{\mathrm{b}}$ & 4,000 & 752,000 &, 000 \\
\hline \multirow[t]{4}{*}{ NComunidade } & Rastreamento de Pillai & ,808 & 127,575 & 8,000 & 1506,000 &, 000 \\
\hline & Lambda de Wilks &, 197 & $235,461^{b}$ & 8,000 & 1504,000 &, 000 \\
\hline & $\begin{array}{l}\text { Rastreamento de } \\
\text { Hotelling }\end{array}$ & 4,048 & 380,030 & 8,000 & 1502,000 &, 000 \\
\hline & Maior raiz de Roy & 4,042 & $760,906^{\mathrm{c}}$ & 4,000 & 753,000 &, 000 \\
\hline
\end{tabular}

a. Design: Interceptação + NComunidade

b. Estatística exata

c. A estatística é um limite superior em $\mathrm{F}$, que gera um limite inferior no nível de significância. 
Figura 8. Hipótese 1 - Comunidade - Kruskal-Wallis - Instituição X

Estatísticas descritivas

\begin{tabular}{|l|r|r|r|r|r|}
\hline & N & \multicolumn{1}{|c|}{ Média } & Erro Desvio & \multicolumn{1}{c|}{ Mínim0 } & \multicolumn{1}{c|}{ Máxim0 } \\
\hline CM1 & 758 & 3,782 &, 8652 & 1,0 & 5,0 \\
CM2 & 758 & 3,615 &, 9188 & 1,0 & 5,0 \\
CM3 & 758 & 3,77 & 1,113 & 1 & 5 \\
Sat_Com & 758 & 3,30 &, 990 & 1 & 5 \\
NComunidade & 758 & 1,73 &, 717 & 1 & 3 \\
\hline
\end{tabular}

Classificações

\begin{tabular}{|ll|r|r|}
\hline & NComunidade & N & $\begin{array}{c}\text { Postos de } \\
\text { média }\end{array}$ \\
\hline CM1 & 1 & 325 & 546,49 \\
& 2 & 313 & 300,64 \\
& 3 & 120 & 132,94 \\
& Total & 758 & \\
\hline CM2 & 1 & 325 & 547,67 \\
& 2 & 313 & 298,82 \\
& 3 & 120 & 134,48 \\
& Total & 758 & \\
\hline CM3 & 1 & 325 & 539,52 \\
& 2 & 313 & 310,42 \\
& 3 & 120 & 126,30 \\
& Total & 758 & \\
\hline Sat_Com & 1 & 325 & 493,71 \\
& 2 & 313 & 335,56 \\
& 3 & 120 & 184,81 \\
& Total & 758 & \\
\hline
\end{tabular}

Estatísticas de teste ${ }^{a, b}$

\begin{tabular}{|l|r|r|r|r|}
\hline & \multicolumn{1}{|c|}{ CM1 } & \multicolumn{1}{c|}{ CM2 } & \multicolumn{1}{c|}{ CM3 } & Sat_Com \\
\hline Qui-quadrado & 393,766 & 397,042 & 395,923 & 215,197 \\
df & 2 & 2 & 2 & 2 \\
Significância Sig. &, 000 &, 000 &, 000 &, 000 \\
\hline
\end{tabular}

a. Teste Kruskal Wallis

b. Variável de Agrupamento: NComunidade 
Figura 9. Hipótese 1 - Comunidade - Médias das Ordens - Instituição X

\begin{tabular}{|c|c|c|c|c|c|c|c|}
\hline \multicolumn{8}{|c|}{ Comparaçöes múltiplas } \\
\hline \multicolumn{8}{|l|}{ Bonferroni } \\
\hline Variável dependente & (l) NComunidade & (J) NComunidade & $\begin{array}{l}\text { Diferença } \\
\text { média (I-J) }\end{array}$ & Erro Padrão & Sig. & Limite inferior & $\begin{array}{l}\text { Limite } \\
\text { superior }\end{array}$ \\
\hline \multirow[t]{5}{*}{ CM1 } & \multirow[t]{2}{*}{1} & 2 & $8959^{x}$ & 0477 &, 000 & .781 & 1,010 \\
\hline & & 3 & $1,7147^{*}$ &, 0644 &, 000 & 1,560 & 1,869 \\
\hline & 2 & 1 &,$- 8959^{*}$ & 0477 &, 000 & $-1,010$ &,- 781 \\
\hline & \multirow[t]{2}{*}{3} & 1 & $-1,7147^{n}$ & .0644 &, 000 & $-1,869$ & $-1,560$ \\
\hline & & 2 &,$- 8188^{\star}$ & 0647 &, 000 &,- 974 &,- 664 \\
\hline \multirow[t]{4}{*}{ CM2 } & \multirow[t]{2}{*}{1} & 2 & $9503^{x}$ & 0505 &, 000 & .829 & 1,071 \\
\hline & & 3 & $1,8303^{*}$ & 0681 &, 000 & 1,667 & 1,994 \\
\hline & \multirow[t]{2}{*}{2} & 1 &,$- 9503^{x}$ & 0505 &, 000 & $-1,071$ &,- 829 \\
\hline & & 3 & $8800^{*}$ & 0685 &, 000 &, 716 & 1,044 \\
\hline \multirow{5}{*}{ CM3 } & 1 & 3 & $2,314^{*}$ & ,081 &, 000 & 2,12 & 2,51 \\
\hline & \multirow[t]{2}{*}{2} & 1 & $-1,064^{n}$ &, 060 &, 000 & $-1,21$ &,- 92 \\
\hline & & 3 & $1,250^{\circ}$ & ,081 &, 000 & 1,05 & 1,44 \\
\hline & \multirow[t]{2}{*}{3} & 1 & $-2,314^{x}$ &, 081 &, 000 & $-2,51$ & $-2,12$ \\
\hline & & 2 & $-1,250^{\circ}$ & 081 &, 000 & $-1,44$ & $-1,05$ \\
\hline \multirow[t]{6}{*}{ Sat_Com } & \multirow[t]{2}{*}{1} & 2 &, $719^{x}$ &, 066 &, 000 & 56 & 88 \\
\hline & & 3 & $1,484^{*}$ &, 090 &, 000 & 1,27 & 1,70 \\
\hline & \multirow[t]{2}{*}{2} & 1 &,$- 719^{x}$ &, 066 &, 000 &,- 88 &,- 56 \\
\hline & & 3 & $765^{\times}$ &, 090 &, 000 &, 55 & 98 \\
\hline & \multirow[t]{2}{*}{3} & 1 & $-1,484^{x}$ &, 090 &, 000 & $-1,70$ & $-1,27$ \\
\hline & & 2 &,$- 765^{\star}$ & 090 &, 000 &,- 98 &,- 55 \\
\hline
\end{tabular}

*. A diferença média é significativa no nível 0.05 .

Figura 10. Hipótese 1 - Educação - Rastreamento de Pilai - Instituição X

Fatores entre assuntos

\begin{tabular}{|ll|c|}
\hline & N \\
\hline NEducação & 1 & 308 \\
& 2 & 301 \\
& 3 & 149 \\
\hline
\end{tabular}

Testes multivariáveis ${ }^{a}$

\begin{tabular}{|ll|r|r|r|r|r|}
\hline Efeito & & Valor & \multicolumn{1}{c|}{ Z } & \multicolumn{1}{c|}{$\begin{array}{c}\text { df de } \\
\text { hipótese }\end{array}$} & Erro df & Sig. \\
\hline Interceptação & Rastreamento de Pillai &, 957 & $4140,788^{\mathrm{b}}$ & 4,000 & 752,000 &, 000 \\
& Lambda de Wilks &, 043 & $4140,788^{\mathrm{b}}$ & 4,000 & 752,000 &, 000 \\
& Rastreamento de & 22,025 & $4140,788^{\mathrm{b}}$ & 4,000 & 752,000 &, 000 \\
& Hotelling & 22,025 & $4140,788^{\mathrm{b}}$ & 4,000 & 752,000 &, 000 \\
\hline & Maior raiz de Roy &, 871 & 145,275 & 8,000 & 1506,000 &, 000 \\
& Rastreamento de Pillai &, 155 & $288,819^{\mathrm{b}}$ & 8,000 & 1504,000 &, 000 \\
& Lambda de Wilks & 5,262 & 493,924 & 8,000 & 1502,000 &, 000 \\
& Rastreamento de & & & & \\
& Hotelling & 5,229 & $984,318^{\mathrm{c}}$ & 4,000 & 753,000 &, 000 \\
\hline
\end{tabular}

a. Design: Interceptação + NEducação

b. Estatística exata

c. A estatística é um limite superior em $F$, que gera um limite inferior no nivel de significância. 
Figura 11. Hipótese 1 - Educação - Kruskal-Wallis - Instituição X

Estatísticas descritivas

\begin{tabular}{|l|r|r|r|r|r|}
\hline & $\mathrm{N}$ & \multicolumn{1}{|c|}{ Média } & Erro Desvio & \multicolumn{1}{c|}{ Mínimo } & \multicolumn{1}{c|}{ Máximo } \\
\hline ED1 & 758 & 3,797273527 &, 8716744935 & 1,000000000 & 5,000000000 \\
ED2 & 758 & 2,960 & 1,2199 & 1,0 & 5,0 \\
ED3 & 758 & 4,22 & 1,036 & 1 & 5 \\
Sat_Edu & 758 & 3,35 & 1,033 & 1 & 5 \\
NEducação & 758 & 1,79 &, 748 & 1 & 3 \\
\hline
\end{tabular}

Classificações

\begin{tabular}{|ll|r|r|}
\hline & NEducação & N & $\begin{array}{c}\text { Postos de } \\
\text { média }\end{array}$ \\
\hline ED1 & 1 & 308 & 552,37 \\
& 2 & 301 & 320,30 \\
& 3 & 149 & 141,74 \\
& Total & 758 & \\
\hline ED2 & 1 & 308 & 574,31 \\
& 2 & 301 & 301,72 \\
& 3 & 149 & 133,94 \\
& Total & 758 & \\
\hline ED3 & 1 & 308 & 517,94 \\
& 2 & 301 & 358,99 \\
& 3 & 149 & 134,77 \\
& Total & 758 & \\
\hline Sat_Edu & 1 & 308 & 498,42 \\
& 2 & 301 & 334,36 \\
& 3 & 149 & 224,85 \\
& Total & 758 & \\
\hline
\end{tabular}

Estatísticas de teste ${ }^{a, b}$

\begin{tabular}{|l|r|r|r|r|}
\hline & \multicolumn{1}{|c|}{ ED1 } & ED2 & ED3 & Sat_Edu \\
\hline Qui-quadrado & 395,697 & 477,552 & 375,688 & 196,675 \\
df & 2 & 2 & 2 & 2 \\
Significância Sig. &, 000 &, 000 &, 000 &, 000 \\
\hline
\end{tabular}

a. Teste Kruskal Wallis

b. Variável de Agrupamento: NEducação 
Figura 12. Hipótese 1 - Educação - Médias das Ordens - Instituição X

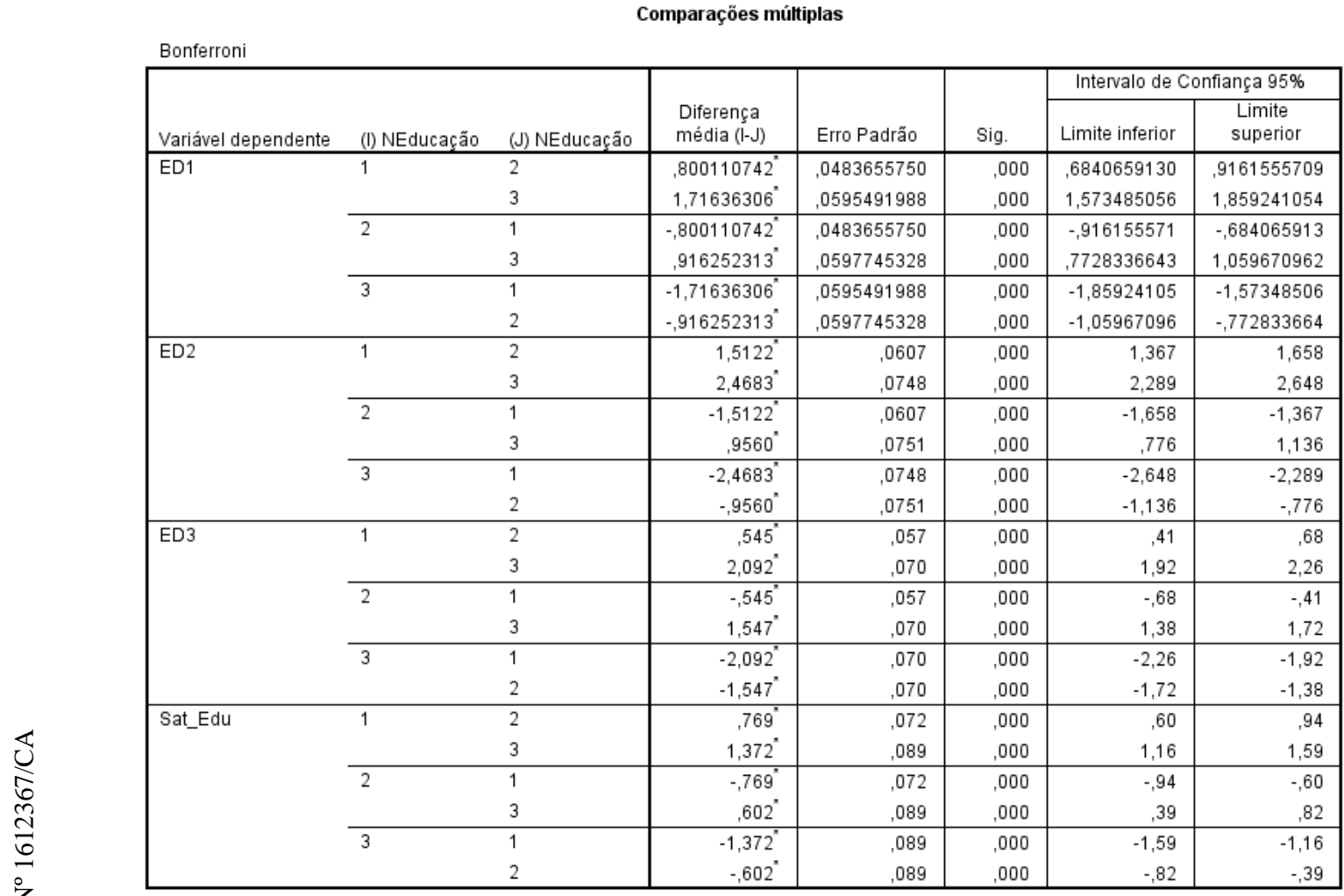

*. A diferença média é significativa no nível 0.05

Figura 13. Hipótese 1 - Percepção 1 - Rastreamento de Pilai - Instituição X

Fatores entre assuntos
\begin{tabular}{|ll|r|}
\hline & \multicolumn{1}{|c|}{$\mathrm{N}$} \\
\hline NPercepção & 1 & 321 \\
& 2 & 346 \\
& 3 & 91 \\
\hline
\end{tabular}

Testes multivariáveis ${ }^{a}$

\begin{tabular}{|ll|r|r|r|r|r|}
\hline Efeito & & \multicolumn{1}{c|}{ Valor } & \multicolumn{1}{c|}{ Z } & \multicolumn{1}{c|}{$\begin{array}{c}\text { df de } \\
\text { hipótese }\end{array}$} & \multicolumn{1}{c|}{ Erro df } & Sig. \\
\hline Interceptação & Rastreamento de Pillai &, 953 & $1243,264^{\mathrm{b}}$ & 12,000 & 744,000 &, 000 \\
& Lambda de Wilks &, 047 & $1243,264^{\mathrm{b}}$ & 12,000 & 744,000 &, 000 \\
& Rastreamento de & 20,053 & $1243,264^{\mathrm{b}}$ & 12,000 & 744,000 &, 000 \\
& Hotelling & 20,053 & $1243,264^{\mathrm{b}}$ & 12,000 & 744,000 &, 000 \\
\hline & Maior raiz de Roy &, 823 & 43,437 & 24,000 & 1490,000 &, 000 \\
\hline NPercepção & Rastreamento de Pillai &, 198 & $77,415^{\mathrm{b}}$ & 24,000 & 1488,000 &, 000 \\
& Lambda de Wilks & 3,950 & 122,280 & 24,000 & 1486,000 &, 000 \\
& Rastreamento de & 3,923 & $243,534^{\mathrm{c}}$ & 12,000 & 745,000 &, 000 \\
\hline
\end{tabular}

a. Design: Interceptação + NPercepção

b. Estatística exata

c. A estatística é um limite superior em $\mathrm{F}$, que gera um limite inferior no nível de significância. 
Figura 14. Hipótese 1 - Percepção1 - Kruskal-Wallis - Instituição X

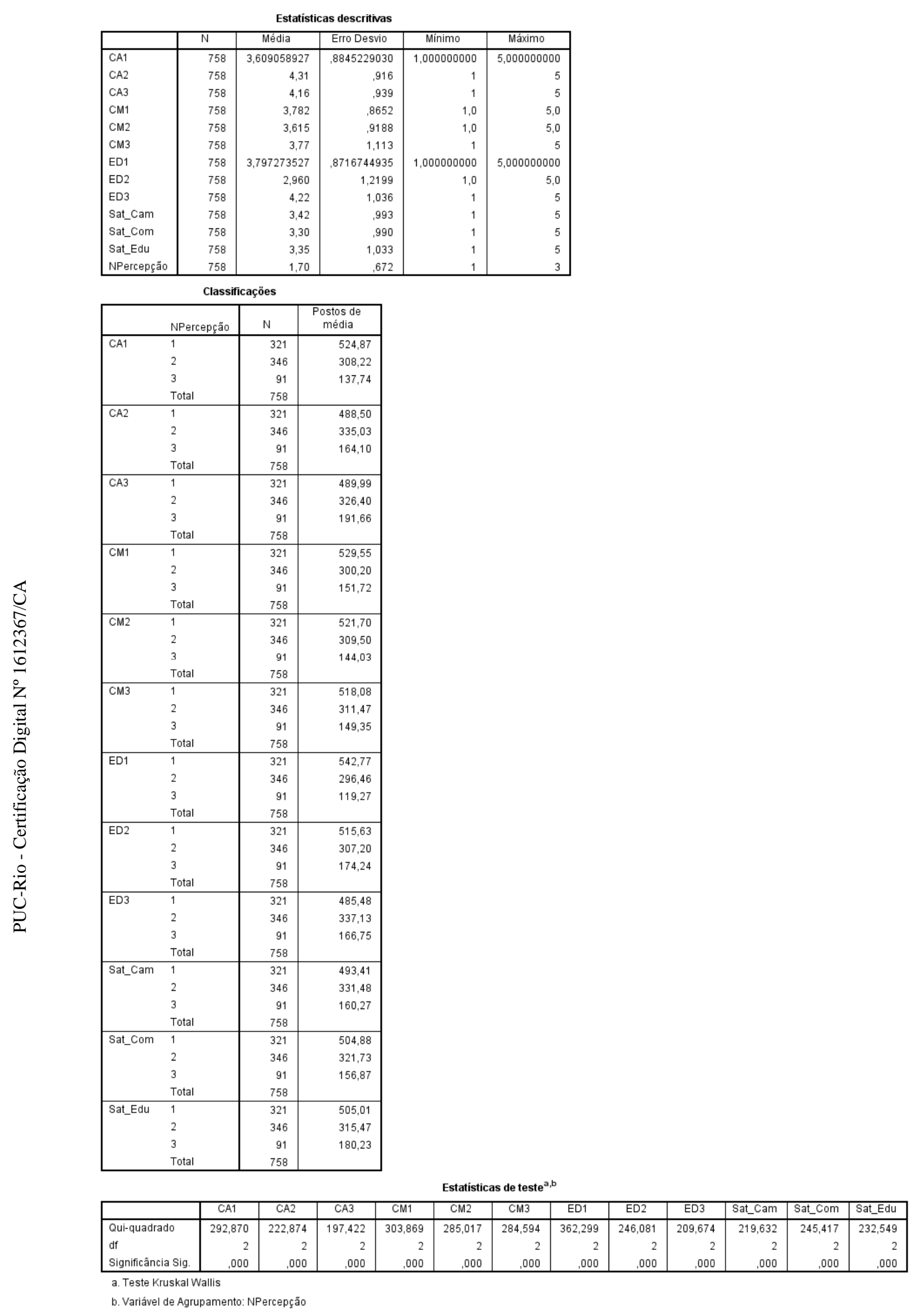


Figura 15. Hipótese 1 - Percepção 1 - Médias das Ordens - Instituição X

Comparaçöes múttiplas

\begin{tabular}{|c|c|c|c|c|c|c|c|}
\hline \multirow[b]{2}{*}{ Variável dependente } & \multirow[b]{2}{*}{ (l) NPercepção } & \multirow[b]{2}{*}{ (J) NPercepçã̃o } & \multirow[b]{2}{*}{$\begin{array}{l}\text { Diferença } \\
\text { média (I-J) }\end{array}$} & \multirow[b]{2}{*}{ Erro Padrão } & \multirow[b]{2}{*}{ Sig. } & \multicolumn{2}{|c|}{ Intervalo de Confiança 95\% } \\
\hline & & & & & & Limite inferior & $\begin{array}{l}\text { Limite } \\
\text { superior }\end{array}$ \\
\hline \multirow[t]{6}{*}{ Rank of CA1 } & 1 & 2 & $216,652508^{x}$ & 13,218190 & .000 & 184,93775 & 248,36727 \\
\hline & & 3 & $387,134453^{*}$ & 20,256996 &, 000 & 338,53130 & 435,73761 \\
\hline & 2 & 1 & $-216,652508^{x}$ & 13,218190 &, 000 & $-248,36727$ & $-184,93775$ \\
\hline & & 3 & $170,481944^{x}$ & 20,094704 & .000 & 122,26818 & 218,69571 \\
\hline & 3 & 1 & $-387,134453^{*}$ & 20,256996 &, 000 & $-435,73761$ & $-338,53130$ \\
\hline & & 2 & $-170,481944^{n}$ & 20,094704 & .000 & $-218,69571$ & $-122,26818$ \\
\hline Rank of CA2 & 1 & 2 & $153,470986^{n}$ & 12,892829 & .000 & 122,53687 & 184,40510 \\
\hline & & 3 & $324,394047^{*}$ & 19,758377 & .000 & 276,98724 & 371,80085 \\
\hline & 2 & 1 & $-153,470986^{*}$ & 12,892829 & .000 & $-184,40510$ & $-122,53687$ \\
\hline & & 3 & $170,923061^{\circ}$ & 19,600080 & .000 & 123,89606 & 217,95006 \\
\hline & 3 & 1 & $-324,394047^{*}$ & 19,758377 & .000 & $-371,80085$ & $-276,98724$ \\
\hline & & 2 & $-170,923061^{*}$ & 19,600080 & .000 & $-217,95006$ & $-123,89606$ \\
\hline Rank of CA3 & 1 & 2 & $163,594700^{\circ}$ & 13,518199 & .000 & 131,16012 & 196,02928 \\
\hline & & 3 & $298,331314^{*}$ & 20,716762 & .000 & 248,62503 & 348,03760 \\
\hline & 2 & 1 & $-163,594700^{n}$ & 13,518199 & .000 & $-196,02928$ & $-131,16012$ \\
\hline & & 3 & $134,736613^{*}$ & 20,550787 & .000 & 85,42856 & 184,04467 \\
\hline & 3 & 1 & $-298,331314^{*}$ & 20,716762 & .000 & $-348,03760$ & $-248,62503$ \\
\hline & & 2 & $-134,736613^{*}$ & 20,550787 &, 000 & $-184,04467$ & $-85,42856$ \\
\hline Rank of CM1 & 1 & 2 & $229,359430^{*}$ & 12,943910 & .000 & 198,30276 & 260,41610 \\
\hline & & 3 & $377,834737^{\circ}$ & 19,836659 & .000 & 330,24011 & 425,42937 \\
\hline & 2 & 1 & $-229,359430^{n}$ & 12,943910 & .000 & $-260,41610$ & $-198,30276$ \\
\hline & & 3 & $148,475306^{*}$ & 19,677735 & .000 & 101,26199 & 195,68863 \\
\hline & 3 & 1 & $-377,834737^{*}$ & 19,836659 & .000 & $-425,42937$ & $-330,24011$ \\
\hline & & 2 & $-148,475306^{*}$ & 19,677735 & .000 & $-195,68863$ & $-101,26199$ \\
\hline Rank of CM2 & 1 & 2 & $212,204050^{\circ}$ & 13,202043 & .000 & 180,52803 & 243,88007 \\
\hline & & 3 & $377,671083^{*}$ & 20,232250 & .000 & 329,12730 & 426,21487 \\
\hline & 2 & 1 & $-212,204050^{*}$ & 13,202043 & .000 & $-243,88007$ & $-180,52803$ \\
\hline & & 3 & $165,467033^{*}$ & 20,070156 & .000 & 117,31217 & 213,62190 \\
\hline & 3 & 1 & $-377,671083^{n}$ & 20,232250 & .000 & $-426,21487$ & $-329,12730$ \\
\hline & & 2 & $-165,467033^{*}$ & 20,070156 & .000 & $-213,62190$ & $-117,31217$ \\
\hline Rank of $\mathrm{CM} 3$ & 1 & 2 & $206,609561^{*}$ & 12,890949 & .000 & 175,67996 & 237,53916 \\
\hline & & 3 & $368,724676^{*}$ & 19,755495 & .000 & 321,32478 & 416,12457 \\
\hline & 2 & 1 & $-206,609561^{n}$ & 12,890949 & .000 & $-237,53916$ & $-175,67996$ \\
\hline & & 3 & $162,115115^{*}$ & 19,597222 & .000 & 115,09497 & 209,13526 \\
\hline & 3 & 1 & $-368,724676^{n}$ & 19,755495 & .000 & $-416,12457$ & $-321,32478$ \\
\hline & & 2 & $-162,115115^{*}$ & 19,597222 & .000 & $-209,13526$ & $-115,09497$ \\
\hline Rank of ED1 & 1 & 2 & $246,310270^{\circ}$ & 12,174884 & .000 & 217,09874 & 275,52180 \\
\hline & & 3 & $423,499418^{*}$ & 18,658120 & .000 & 378,73249 & 468,26635 \\
\hline & 2 & 1 & $-246,310270^{\circ}$ & 12,174884 & .000 & $-275,52180$ & $-217,09874$ \\
\hline & & 3 & $177,189148^{\circ}$ & 18,508638 & .000 & 132,78087 & 221,59742 \\
\hline & 3 & 1 & $-423,499418^{n}$ & 18,658120 & .000 & $-468,26635$ & $-378,73249$ \\
\hline & & 2 & $-177,189148^{*}$ & 18,508638 & .000 & $-221,59742$ & $-132,78087$ \\
\hline Rank of ED2 & 1 & 2 & $208,431082^{n}$ & 13,835681 & .000 & 175,23476 & 241,62740 \\
\hline & & 3 & $341,389904^{*}$ & 21,203306 &, 000 & 290,51624 & 392,26357 \\
\hline & 2 & 1 & $-208,431082^{n}$ & 13,835681 & .000 & $-241,62740$ & $-175,23476$ \\
\hline & & 3 & $132,958823^{*}$ & 21,033433 & .000 & 82,49274 & 183,42491 \\
\hline & 3 & 1 & $-341,389904^{\prime \prime}$ & 21,203306 & .000 & $-392,26357$ & $-290,51624$ \\
\hline & & 2 & $-132,958823^{*}$ & 21,033433 & .000 & $-183,42491$ & $-82,49274$ \\
\hline Rank of ED3 & 1 & 2 & $148,349806^{\circ}$ & 13,163713 & .000 & 116,76575 & 179,93386 \\
\hline & & 3 & $318,734056^{*}$ & 20,173509 & .000 & 270,33121 & 367,13690 \\
\hline & 2 & 1 & $-148,349806^{n}$ & 13,163713 & .000 & $-179,93386$ & $-116,76575$ \\
\hline & & 3 & $170,384250^{\circ}$ & 20,011886 &, 000 & 122,36919 & 218,39931 \\
\hline & 3 & 1 & $-318,734056^{*}$ & 20,173509 & .000 & $-367,13690$ & $-270,33121$ \\
\hline & & 2 & $-170,384250^{\circ}$ & 20,011886 & .000 & $-218,39931$ & $-122,36919$ \\
\hline Rank of Sat_Cam & 1 & 2 & $161,932891^{\circ}$ & 13,479873 & .000 & 129,59027 & 194,27551 \\
\hline & & 3 & $333,141984^{*}$ & 20,658027 & .000 & 283,57662 & 382,70735 \\
\hline & 2 & 1 & $-161,932891^{n}$ & 13,479873 & .000 & $-194,27551$ & $-129,59027$ \\
\hline & & 3 & $171,209093^{*}$ & 20,492522 & .000 & 122,04083 & 220,37735 \\
\hline & 3 & 1 & $-333,141984^{n}$ & 20,658027 & .000 & $-382,70735$ & $-283,57662$ \\
\hline & & 2 & $-171,209093^{n}$ & 20,492522 & .000 & $-220,37735$ & $-122,04083$ \\
\hline Rank of Sat_Com & 1 & 2 & $183,148848^{n}$ & 13,326638 & .000 & 151,17389 & 215,12381 \\
\hline & & 3 & $348,006436^{*}$ & 20,423193 & .000 & 299,00452 & 397,00835 \\
\hline & 2 & 1 & $-183,148848^{n}$ & 13,326638 & .000 & $-215,12381$ & $-151,17389$ \\
\hline & & 3 & $164,857587^{*}$ & 20,259569 & .000 & 116,24826 & 213,46692 \\
\hline & 3 & 1 & $-348,006436^{*}$ & 20,423193 &, 000 & $-397,00835$ & $-299,00452$ \\
\hline & & 2 & $-164,857587^{*}$ & 20,259569 & .000 & $-213,46692$ & $-116,24826$ \\
\hline Rank of Sat_Edu & 1 & 2 & $189,547143^{x}$ & 13,453008 & .000 & 157,26898 & 221,82531 \\
\hline & & 3 & $324,781692^{*}$ & 20,616856 & .000 & 275,31511 & 374,24827 \\
\hline & 2 & 1 & $-189,547143^{n}$ & 13,453008 & .000 & $-221,82531$ & $-157,26898$ \\
\hline & & 3 & $135,234549^{*}$ & 20,451681 & .000 & 86,16428 & 184,30482 \\
\hline & 3 & 1 & $-324,781692^{n}$ & 20,616856 & .000 & $-374,24827$ & $-275,31511$ \\
\hline & & 2 & $-135,234549^{*}$ & 20,451681 & .000 & $-184,30482$ & $-86,16428$ \\
\hline
\end{tabular}

\footnotetext{
*. A diferença média é significativa no nivel 0.05
} 
Figura 16. Hipótese 1 - Percepção 1 - SatisfaçãoCampus Percepção Instituição X

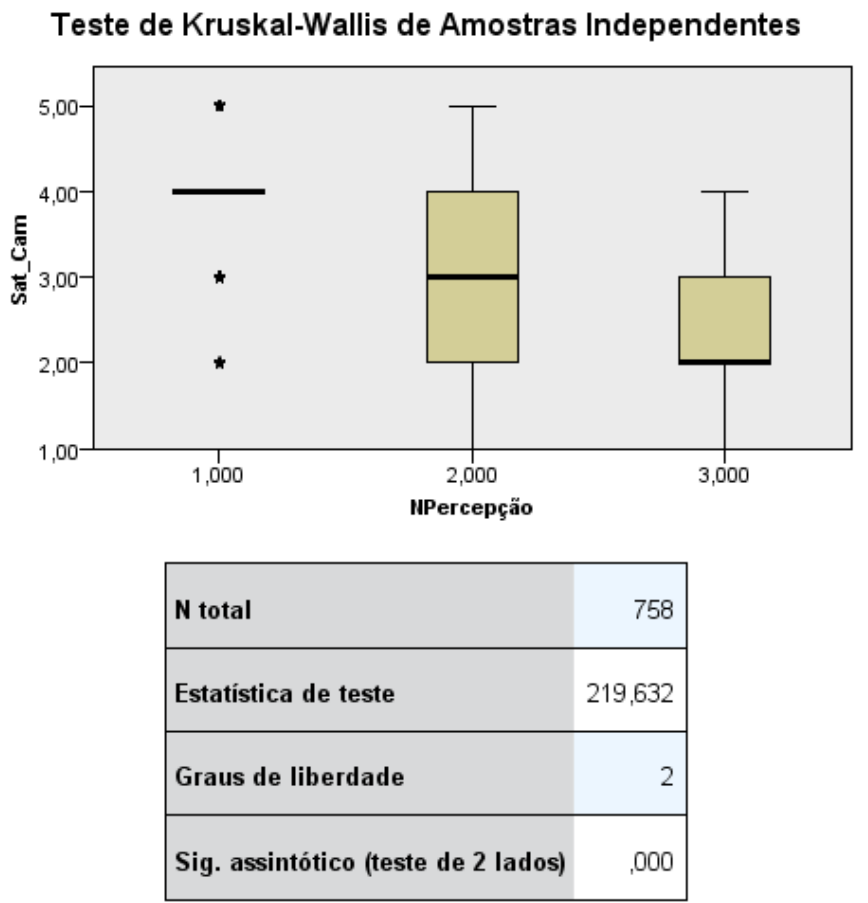

1. A estatística de teste está ajustada para empates.

Figura 17. Hipótese 1 - Percepção 1 - SatisfaçãoComunidade Percepção Instituição X

Teste de Kruskal-Wallis de Amostras Independentes

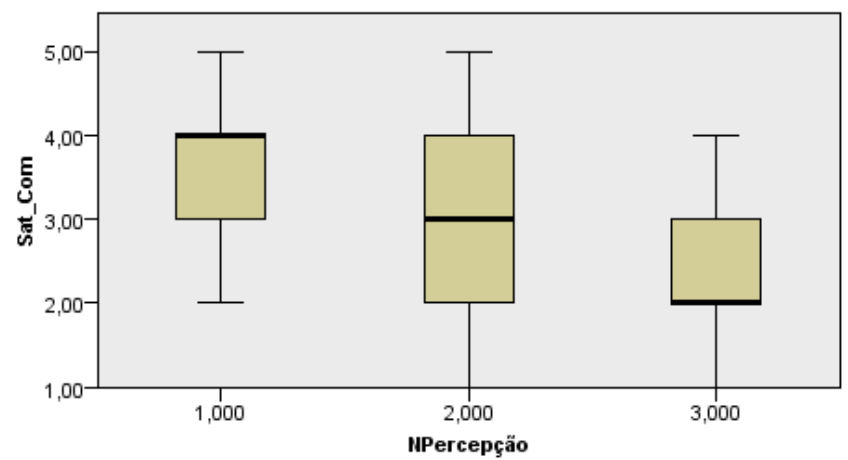

\begin{tabular}{|lr|}
\hline N total & 758 \\
\hline Estatística de teste & 245,417 \\
\hline Graus de liberdade & 2 \\
\hline Sig. assintótico (teste de 2 lados) &, 000 \\
\hline
\end{tabular}

1. A estatística de teste está ajustada para empates. 
Figura 18. Hipótese 1 - Percepção 1 - SatisfaçãoEducação Percepção Instituição X

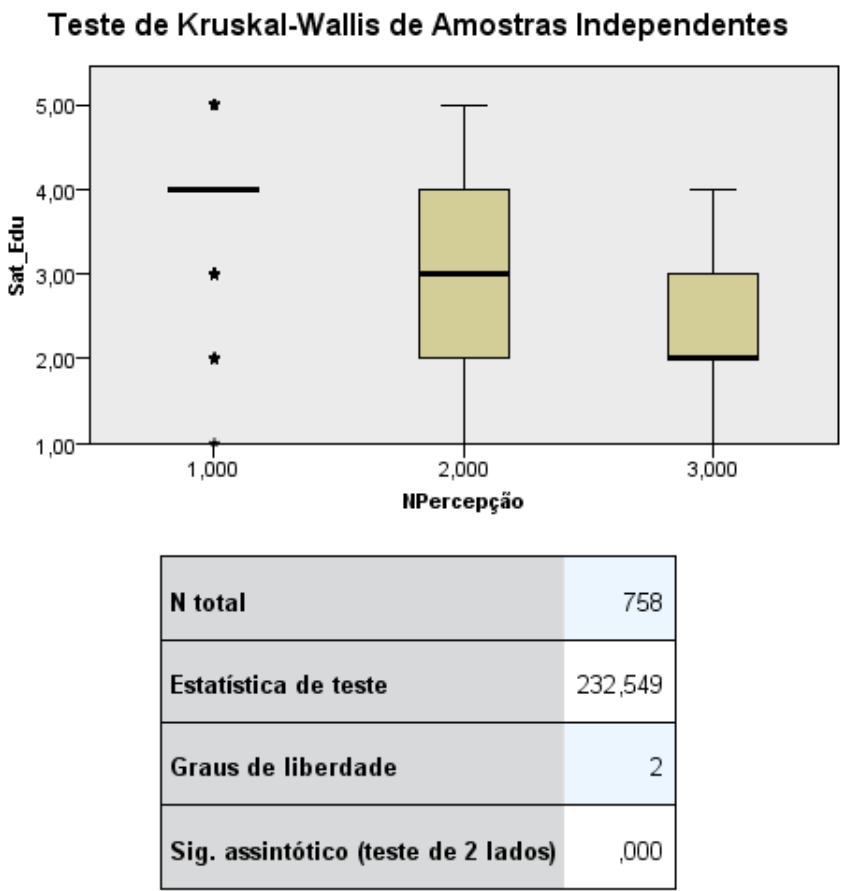

1. A estatística de teste está ajustada para empates.

Figura 19. Hipótese 1 - Percepção 2 - Rastreamento de Pilai - Instituição X

Fatores entre assuntos
\begin{tabular}{|rl|r|}
\hline & \multicolumn{1}{|c|}{$\mathrm{N}$} \\
\hline NPercep̧̧ão & 1 & 321 \\
& 2 & 346 \\
& 3 & 91 \\
\hline
\end{tabular}

\begin{tabular}{|ll|r|r|r|r|r|}
\hline Efeito & \multicolumn{1}{|c|}{$\begin{array}{c}\text { df de } \\
\text { hipótese }\end{array}$} & \multicolumn{1}{c|}{ Erro df } & \multicolumn{1}{c|}{ Sig. } \\
\hline Interceptaçãoo & Rastreamento de Pillai &, 917 & $2063,584^{\mathrm{b}}$ & 4,000 & 752,000 &, 000 \\
& Lambda de Wilks &, 083 & $2063,584^{\mathrm{b}}$ & 4,000 & 752,000 &, 000 \\
& Rastreamento de & 10,977 & $2063,584^{\mathrm{b}}$ & 4,000 & 752,000 &, 000 \\
& Hotelling & 10,977 & $2063,584^{\mathrm{b}}$ & 4,000 & 752,000 &, 000 \\
& Maior raiz de Roy &, 805 & 126,760 & 8,000 & 1506,000 &, 000 \\
\hline NPercep̧̧ão & Rastreamento de Pillai &, 196 & $236,845^{\mathrm{b}}$ & 8,000 & 1504,000 &, 000 \\
& Lambda de Wilks & 4,104 & 385,226 & 8,000 & 1502,000 &, 000 \\
& Rastreamento de & 4,103 & $772,358^{\mathrm{C}}$ & 4,000 & 753,000 &, 000 \\
& Hotelling & & & &
\end{tabular}

a. Design: Interceptação + NPercepção

b. Estatística exata

c. A estatística é um limite superior em $F$, que gera um limite inferior no nivel de significância. 
Figura 20. Hipótese 1 - Percepção 2 - Kruskal-Wallis - Instituição X

\begin{tabular}{|l|r|c|r|r|r|}
\multicolumn{7}{c|}{ Estatísticas descritivas } \\
\begin{tabular}{|l|r|r|r|r|r|}
\hline & Média & Erro Desvio & \multicolumn{1}{c|}{ Mínimo } & \multicolumn{1}{c|}{ Máximo } \\
\hline Campus & 758 & 4,026238640 &, 6983602156 & 1,444444444 & 5,000000000 \\
Comunidade & 758 & 3,720976253 &, 7777479465 & 1,000000000 & 5,000000000 \\
Educação & 758 & 3,657798300 &, 8448460691 & 1,000000000 & 5,000000000 \\
Satisfação & 758 & 3,355321020 &, 8598128414 & 1,000000000 & 5,000000000 \\
NPercepção & 758 & 1,70 &, 672 & 1 & 3 \\
\hline
\end{tabular}
\end{tabular}

Classificaçōes

\begin{tabular}{|ll|r|r|}
\hline & NPercepção & \multicolumn{1}{|c|}{ N } & \multicolumn{1}{c|}{$\begin{array}{c}\text { Postos de } \\
\text { média }\end{array}$} \\
\hline Campus & 1 & 321 & 550,30 \\
& 2 & 346 & 294,04 \\
& 3 & 91 & 101,92 \\
& Total & 758 & \\
\hline Comunidade & 1 & 321 & 562,79 \\
& 2 & 346 & 286,12 \\
& 3 & 91 & 88,01 \\
& Total & 758 & \\
\hline Educação & 1 & 321 & 552,83 \\
& 2 & 346 & 291,57 \\
& 3 & 91 & 102,43 \\
& Total & 758 & \\
\hline Satisfação & 1 & 321 & 530,61 \\
& 2 & 346 & 305,77 \\
& 3 & 91 & 126,79 \\
& Total & 758 & \\
\hline
\end{tabular}

Estatísticas de teste ${ }^{a, b}$

\begin{tabular}{|l|r|r|r|r|}
\hline & Campus & Comunidade & Educação & Satisfação \\
\hline Qui-quadrado & 395,446 & 451,233 & 402,944 & 319,264 \\
df & 2 & 2 & 2 & 2 \\
Significância Sig. &, 000 &, 000 &, 000 &, 000 \\
\hline
\end{tabular}

a. Teste Kruskal Wallis

b. Variável de Agrupamento: NPercepção 
Figura 21. Hipótese 1 - Percepção 2 - Médias das Ordens - Instituição X

Comparaçōes múltiplas

\begin{tabular}{|c|c|c|c|c|c|c|c|}
\hline \multirow[b]{2}{*}{ Variável dependente } & \multirow[b]{2}{*}{ (I) NPercepção } & \multirow[b]{2}{*}{ (J) NPercepção } & \multirow[b]{2}{*}{$\begin{array}{l}\text { Diferença } \\
\text { média (I-J) }\end{array}$} & \multirow[b]{2}{*}{ Erro Padrão } & \multirow[b]{2}{*}{ Sig. } & \multicolumn{2}{|c|}{ Intervalo de Confiança 95\% } \\
\hline & & & & & & Limite inferior & $\begin{array}{l}\text { Limite } \\
\text { superior }\end{array}$ \\
\hline \multirow[t]{6}{*}{ Rank of Campus } & \multirow[t]{2}{*}{1} & 2 & $256,257383^{*}$ & 11,724873 & .000 & 228,12558 & 284,38919 \\
\hline & & 3 & $448,384598^{*}$ & 17,968474 &, 000 & 405,27235 & 491,49684 \\
\hline & \multirow[t]{2}{*}{2} & 1 & $-256,257383^{n}$ & 11,724873 & .000 & $-284,38919$ & $-228,12558$ \\
\hline & & 3 & $192,127215^{*}$ & 17,824518 & .000 & 149,36037 & 234,89406 \\
\hline & \multirow[t]{2}{*}{3} & 1 & $-448,384598^{*}$ & 17,968474 &, 000 & $-491,49684$ & $-405,27235$ \\
\hline & & 2 & $-192,127215^{*}$ & 17,824518 &, 000 & $-234,89406$ & $-149,36037$ \\
\hline \multirow[t]{6}{*}{ Rank of Comunidade } & \multirow[t]{2}{*}{1} & 2 & $276,672668^{*}$ & 10,773281 &, 000 & 250,82404 & 302,52129 \\
\hline & & 3 & $474,778731^{*}$ & 16,510151 & .000 & 435,16548 & 514,39198 \\
\hline & \multirow[t]{2}{*}{2} & 1 & $-276,672668^{*}$ & 10,773281 & .000 & $-302,52129$ & $-250,82404$ \\
\hline & & 3 & $198,106063^{*}$ & 16,377877 &, 000 & 158,81018 & 237,40195 \\
\hline & \multirow[t]{2}{*}{3} & 1 & $-474,778731^{*}$ & 16,510151 & .000 & $-514,39198$ & $-435,16548$ \\
\hline & & 2 & $-198,106063^{*}$ & 16,377877 & , 000 & $-237,40195$ & $-158,81018$ \\
\hline \multirow[t]{6}{*}{ Rank of Educação } & \multirow[t]{2}{*}{1} & 2 & $261,262186^{*}$ & 11,615772 &, 000 & 233,39215 & 289,13222 \\
\hline & & 3 & $450,400089^{*}$ & 17,801275 &, 000 & 407,68901 & 493,11117 \\
\hline & \multirow[t]{2}{*}{2} & 1 & $-261,262186^{*}$ & 11,615772 & .000 & $-289,13222$ & $-233,39215$ \\
\hline & & 3 & $189,137903^{\star}$ & 17,658657 &, 000 & 146,76901 & 231,50680 \\
\hline & \multirow[t]{2}{*}{3} & 1 & $-450,400089^{*}$ & 17,801275 &, 000 & $-493,11117$ & $-407,68901$ \\
\hline & & 2 & $-189,137903^{*}$ & 17,658657 &, 000 & $-231,50680$ & $-146,76901$ \\
\hline \multirow[t]{6}{*}{ Rank of Satisfação } & \multirow[t]{2}{*}{1} & 2 & $224,843476^{*}$ & 12,799811 & .000 & 194,13254 & 255,55441 \\
\hline & & 3 & $403,827993^{*}$ & 19,615826 &, 000 & 356,76321 & 450,89277 \\
\hline & \multirow[t]{2}{*}{2} & 1 & $-224,843476^{*}$ & 12,799811 & .000 & $-255,55441$ & $-194,13254$ \\
\hline & & 3 & $178,984517^{*}$ & 19,458672 & .000 & 132,29680 & 225,67223 \\
\hline & \multirow[t]{2}{*}{3} & 1 & $-403,827993^{*}$ & 19,615826 &, 000 & $-450,89277$ & $-356,76321$ \\
\hline & & 2 & $-178,984517^{*}$ & 19,458672 &, 000 & $-225,67223$ & $-132,29680$ \\
\hline
\end{tabular}

*. A diferença média é significativa no nível 0.05 .

Figura 22. Hipótese 2 - Rastreamento de Pilai - Instituição X

Fatores entre assuntos

\begin{tabular}{|cl|c|}
\hline & $\mathrm{N}$ \\
\hline NSatisfação & 1 & 275 \\
& 2 & 288 \\
& 3 & 195 \\
\hline
\end{tabular}

Testes multivariáveis ${ }^{a}$

\begin{tabular}{|c|c|c|c|c|c|c|}
\hline Efeito & & Valor & Z & $\begin{array}{c}\text { df de } \\
\text { hipótese }\end{array}$ & Erro df & Sig. \\
\hline \multirow[t]{4}{*}{ Interceptação } & Rastreamento de Pillai & 970 & $6091,985^{\mathrm{b}}$ & 4,000 & 752,000 & .000 \\
\hline & Lambda de Wilks &, 030 & $6091,985^{\mathrm{b}}$ & 4,000 & 752,000 &, 000 \\
\hline & $\begin{array}{l}\text { Rastreamento de } \\
\text { Hotelling }\end{array}$ & 32,404 & $6091,985^{\mathrm{b}}$ & 4,000 & 752,000 &, 000 \\
\hline & Maior raiz de Roy & 32,404 & $6091,985^{\mathrm{b}}$ & 4,000 & 752,000 &, 000 \\
\hline \multirow[t]{4}{*}{ NSatisfação } & Rastreamento de Pillai & 907 & 156,086 & 8,000 & 1506,000 &, 000 \\
\hline & Lambda de Wilks & ,129 & $335,836^{\mathrm{b}}$ & 8,000 & 1504,000 &, 000 \\
\hline & $\begin{array}{l}\text { Rastreamento de } \\
\text { Hotelling }\end{array}$ & 6,489 & 609,155 & 8,000 & 1502,000 &, 000 \\
\hline & Maior raiz de Roy & 6,446 & $1213,531^{\mathrm{c}}$ & 4,000 & 753,000 &, 000 \\
\hline
\end{tabular}

a. Design: Interceptação + NSatisfação

b. Estatística exata

c. A estatística é um limite superior em $F$, que gera um limite inferior no nível de significância. 
Figura 23. Hipótese 2 - Kruskal-Wallis - Instituição X

Estatísticas descritivas

\begin{tabular}{|l|r|r|r|r|r|}
\hline & \multicolumn{1}{|c|}{ N } & \multicolumn{1}{|c|}{ Média } & Erro Desvio & Mínimo & Máximo \\
\hline Sat_Cam & 758 & 3,42 &, 993 & 1 & 5 \\
Sat_Com & 758 & 3,30 &, 990 & 1 & 5 \\
Sat_Edu & 758 & 3,35 & 1,033 & 1 & 5 \\
Part & 758 & 4,23 &, 911 & 1 & 5 \\
NSatisfação & 758 & 1,89 &, 781 & 1 & 3 \\
\hline
\end{tabular}

Classificações

\begin{tabular}{|c|c|c|c|}
\hline & NSatisfação & $N$ & $\begin{array}{c}\text { Postos de } \\
\text { média }\end{array}$ \\
\hline \multirow[t]{4}{*}{ Sat_Cam } & 1 & 275 & 559,63 \\
\hline & 2 & 288 & 370,24 \\
\hline & 3 & 195 & 139,15 \\
\hline & Total & 758 & \\
\hline \multirow[t]{4}{*}{ Sat_Com } & 1 & 275 & 579,06 \\
\hline & 2 & 288 & 350,45 \\
\hline & 3 & 195 & 140,98 \\
\hline & Total & 758 & \\
\hline \multirow[t]{4}{*}{ Sat_Edu } & 1 & 275 & 566,63 \\
\hline & 2 & 288 & 350,89 \\
\hline & 3 & 195 & 157,86 \\
\hline & Total & 758 & \\
\hline \multirow[t]{4}{*}{ Part } & 1 & 275 & 405,44 \\
\hline & 2 & 288 & 333,74 \\
\hline & 3 & 195 & 410,50 \\
\hline & Total & 758 & \\
\hline
\end{tabular}

Estatísticas de teste ${ }^{a, b}$

\begin{tabular}{|l|r|r|r|r|}
\hline & Sat_Cam & Sat_Com & Sat_Edu & \multicolumn{1}{|c|}{ Part } \\
\hline Qui-quadrado & 475,456 & 510,700 & 448,202 & 23,968 \\
df & 2 & 2 & 2 & 2 \\
Significância Sig. &, 000 &, 000 &, 000 &, 000 \\
\hline
\end{tabular}

a. Teste Kruskal Wallis

b. Variável de Agrupamento: NSatisfação 
Figura 24. Hipótese 2 - Médias das Ordens - Instituição X

\begin{tabular}{|c|c|c|c|c|c|c|c|}
\hline \multicolumn{8}{|c|}{ Comparaçōes múltiplas } \\
\hline \multicolumn{8}{|l|}{ Bonferroni } \\
\hline \multirow[b]{2}{*}{ Variável dependente } & \multirow[b]{2}{*}{ (I) NSatisfação } & \multirow[b]{2}{*}{ (J) NSatisfação } & \multirow[b]{2}{*}{$\begin{array}{l}\text { Diferença } \\
\text { média (I-J) }\end{array}$} & \multirow[b]{2}{*}{ Erro Padrão } & \multirow[b]{2}{*}{ Sig. } & \multicolumn{2}{|c|}{ Intervalo de Confiança 95\% } \\
\hline & & & & & & Limite inferior & $\begin{array}{l}\text { Limite } \\
\text { superior }\end{array}$ \\
\hline \multirow[t]{6}{*}{ Rank of Sat_Cam } & 1 & 2 & $189,391244^{x}$ & 10,615534 & .000 & 163,92111 & 214,86138 \\
\hline & & 3 & $420,477809^{*}$ & 11,787332 &, 000 & 392,19615 & 448,75947 \\
\hline & 2 & 1 & $-189,391244^{n}$ & 10,615534 &, 000 & $-214,86138$ & $-163,92111$ \\
\hline & & 3 & $231,086565^{*}$ & 11,676434 &, 000 & 203,07098 & 259,10215 \\
\hline & 3 & 1 & $-420,477809^{x}$ & 11,787332 &, 000 & $-448,75947$ & $-392,19615$ \\
\hline & & 2 & $-231,086565^{*}$ & 11,676434 &, 000 & $-259,10215$ & $-203,07098$ \\
\hline \multirow[t]{6}{*}{ Rank of Sat_Com } & 1 & 2 & $228,615638^{n}$ & 10,060362 &, 000 & 204,47754 & 252,75374 \\
\hline & & 3 & $438,084895^{n}$ & 11,170877 &, 000 & 411,28231 & 464,88748 \\
\hline & 2 & 1 & $-228,615638^{n}$ & 10,060362 &, 000 & $-252,75374$ & $-204,47754$ \\
\hline & & 3 & $209,469257^{*}$ & 11,065780 &, 000 & 182,91883 & 236,01968 \\
\hline & 3 & 1 & $-438,084895^{x}$ & 11,170877 &, 000 & $-464,88748$ & $-411,28231$ \\
\hline & & 2 & $-209,469257^{*}$ & 11,065780 &, 000 & $-236,01968$ & $-182,91883$ \\
\hline \multirow[t]{6}{*}{ Rank of Sat_Edu } & 1 & 2 & $215,745492^{*}$ & 11,231123 &, 000 & 188,79836 & 242,69263 \\
\hline & & 3 & $408,771935^{*}$ & 12,470873 &, 000 & 378,85023 & 438,69364 \\
\hline & 2 & 1 & $-215,745492^{*}$ & 11,231123 &, 000 & $-242,69263$ & $-188,79836$ \\
\hline & & 3 & $193,026442^{*}$ & 12,353544 &, 000 & 163,38625 & 222,66663 \\
\hline & 3 & 1 & $-408,771935^{x}$ & 12,470873 & .000 & $-438,69364$ & $-378,85023$ \\
\hline & & 2 & $-193,026442^{*}$ & 12,353544 &, 000 & $-222,666663$ & $-163,38625$ \\
\hline \multirow[t]{6}{*}{ Rank of Part } & 1 & 2 & $71,698681^{\star}$ & 16,759833 &, 000 & 31,48636 & 111,91100 \\
\hline & & 3 & $-5,060000$ & 18,609870 & 1,000 & $-49,71116$ & 39,59116 \\
\hline & 2 & 1 & $-71,698681^{\star}$ & 16,759833 &, 000 & $-111,91100$ & $-31,48636$ \\
\hline & & 3 & $-76,758681^{*}$ & 18,434785 &, 000 & $-120,98976$ & $-32,52760$ \\
\hline & 3 & 1 & 5,060000 & 18,609870 & 1,000 & $-39,59116$ & 49,71116 \\
\hline & & 2 & $76,758681^{*}$ & 18,434785 &, 000 & 32,52760 & 120,98976 \\
\hline
\end{tabular}

*. A diferença média é significativa no nível 0.05

Figura 29. Hipótese 3 - Regressão com Atitude e Comportamento

Estatísticas descritivas
\begin{tabular}{|l|c|r|r|}
\hline & Média & \multicolumn{1}{|c|}{$\begin{array}{c}\text { Desvio } \\
\text { Padrão }\end{array}$} & \multicolumn{1}{c|}{$\mathrm{N}$} \\
\hline Percepção & 3,6292 &, 69215 & 758 \\
Comportamento & 3,5997 &, 72738 & 758 \\
Atitude & 4,3058 &, 57698 & 758 \\
\hline
\end{tabular}

Correlaçöes

\begin{tabular}{|ll|r|r|r|}
\hline & & Percepção & \multicolumn{1}{|c|}{$\begin{array}{c}\text { Comportame } \\
\text { nto }\end{array}$} & \multicolumn{1}{c|}{ Atitude } \\
\hline Correlação de Pearson & Percepção & 1,000 &, 164 &, 049 \\
& Comportamento &, 164 & 1,000 &, 231 \\
& Atitude &, 049 &, 231 & 1,000 \\
\hline Sig. (1 extremidade) & Percep̧ão & &, 000 &, 091 \\
& Comportamento &, 000 &. &, 000 \\
& Atitude &, 091 &, 000 & \\
\hline $\mathrm{N}$ & Percep̧̧ão & 758 & 758 & 758 \\
& Comportamento & 758 & 758 & 758 \\
& Atitude & 758 & 758 & 758 \\
\hline
\end{tabular}

Resumo do modelo

\begin{tabular}{|c|c|c|c|c|c|c|c|c|c|}
\hline \multirow[b]{2}{*}{ Modelo } & \multirow[b]{2}{*}{$\mathrm{R}$} & \multirow[b]{2}{*}{$R$ quadrado } & \multirow[b]{2}{*}{$\begin{array}{l}\mathrm{R} \text { quadrado } \\
\text { ajustado }\end{array}$} & \multirow[b]{2}{*}{$\begin{array}{l}\text { Erro padrão } \\
\text { da estimativa }\end{array}$} & \multicolumn{5}{|c|}{ Estatisticas de mudança } \\
\hline & & & & & $\begin{array}{l}\text { Alteração de } \\
\text { R quadrado }\end{array}$ & Alteração $\mathrm{F}$ & df1 & $\mathrm{df} 2$ & $\begin{array}{c}\text { Sig. Alteração } \\
\text { F }\end{array}$ \\
\hline 1 & $.164^{\mathrm{a}}$ & .027 & .024 & 68363 & .027 & 10,497 & 2 & 755 & .000 \\
\hline
\end{tabular}

a. Preditores: (Constante), Atitude, Comportamento

Coeficientes $^{a}$

\begin{tabular}{|c|c|c|c|c|c|c|c|c|}
\hline \multirow{2}{*}{\multicolumn{2}{|c|}{ Modelo }} & \multicolumn{2}{|c|}{ Coeficientes não padronizados } & \multirow{2}{*}{\begin{tabular}{|c|}
$\begin{array}{c}\text { Coeficientes } \\
\text { padronizados }\end{array}$ \\
Beta \\
\end{tabular}} & \multirow[b]{2}{*}{$t$} & \multirow[b]{2}{*}{ Sig. } & \multicolumn{2}{|c|}{$\begin{array}{c}95,0 \% \text { Intervalo de Confiança } \\
\text { para B }\end{array}$} \\
\hline & & B & Erro Padrão & & & & Limite inferior & $\begin{array}{l}\text { Limite } \\
\text { superior }\end{array}$ \\
\hline \multirow[t]{3}{*}{$\begin{array}{l}1 \\
\end{array}$} & (Constante) & 3,018 & 204 & & 14,766 & .000 & 2,617 & 3,419 \\
\hline & Comportamento & 154 & .035 & 162 & 4,378 &, 000 & .085 & .223 \\
\hline & Atitude & .013 & .044 & .011 &, 303 & .762 &,- 073 & .100 \\
\hline
\end{tabular}

a. Variável Dependente: Percepçåo 